Portland State University

PDXScholar

Summer 7-26-2013

\title{
Special Education Teacher Candidates and Mentors: Case Studies of Collaboration in Pre-service Field Experiences
}

Rebecca Lynn Schulte

Portland State University

Follow this and additional works at: https://pdxscholar.library.pdx.edu/open_access_etds

Part of the Educational Leadership Commons, Other Teacher Education and Professional Development Commons, and the Special Education and Teaching Commons Let us know how access to this document benefits you.

\section{Recommended Citation}

Schulte, Rebecca Lynn, "Special Education Teacher Candidates and Mentors: Case Studies of Collaboration in Pre-service Field Experiences" (2013). Dissertations and Theses. Paper 1028. https://doi.org/10.15760/etd.1028

This Dissertation is brought to you for free and open access. It has been accepted for inclusion in Dissertations and Theses by an authorized administrator of PDXScholar. Please contact us if we can make this document more accessible: pdxscholar@pdx.edu. 
Special Education Teacher Candidates and Mentors:

Case Studies of Collaboration in Pre-service Field Experiences

by

Rebecca Lynn Schulte

A dissertation submitted in partial fulfillment of the requirements for the degree of

Doctor of Education

in

Educational Leadership: Curriculum and Instruction

Dissertation Committee:

Christine Chaillé, Chair

Emily De La Cruz

Leslie Munson

Christina Gildersleeve-Neumann

Portland State University

2013 
(C) 2013 Rebecca Lynn Schulte 


\begin{abstract}
Collaboration between general and special education teachers is essential for students with disabilities to have access to general education curriculum and instruction, and improved outcomes in school. The Individuals with Disabilities Act (IDEA), and No
\end{abstract} Child Left Behind Legislation, include mandates that increase demands for collaboration. However, many general and special education teachers report not feeling prepared to step outside traditional roles to collaborate to meet the needs of this population. Collaboration is also a strong element of teaching and special education standards for teacher preparation. Yet, research shows many teacher education programs lack coursework and field experiences that focus on collaboration. The purpose of this study was to explore experiences special education teacher candidates had in collaboration with general education teachers during student teacher field placements. The research questions include: (a) To what extent are special education student teachers expected to collaborate with general education teachers during field placements; and (b) How are perspectives on collaboration with general education teachers different between special education student teachers and their mentor teachers? 
The study used qualitative multiple-case study design and content analysis. Data were collected across three different school contexts (elementary, middle school, and high school) in which special education candidates were placed for student teaching.

Participants included special education student teachers and their mentor teachers from each setting. Data sources included interviews, a survey of collaborative practices, text analysis of teacher work samples, and field-placement evaluations. Results of the study show many collaborative practices occur across different special education settings to various extents, and special education candidates have opportunities to learn about perspectives on collaboration and collaborative practices with general education teachers from mentor teachers. However, the standards-based student teaching performance measures did not guide or document the learning and experiences of special education student teachers in relation to collaboration with general education teachers.

Recommendations are made for adding guidelines and performance measures in teacher education programs that prepare special education teacher candidates for collaborative roles in schools. 


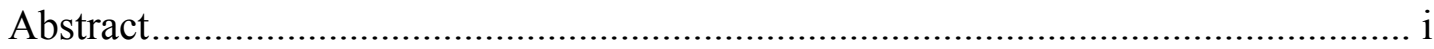

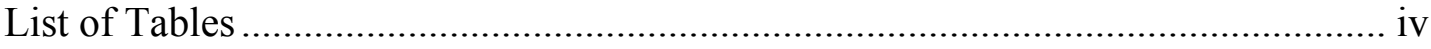

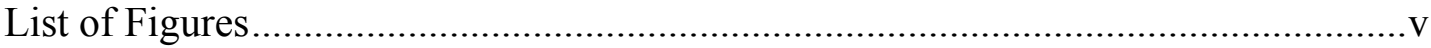

Chapter 1: Introduction

Pilot Study: Reflections on Collaboration ................................................

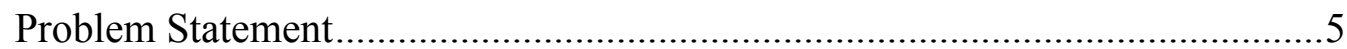

Theoretical Framework............................................................................ 9

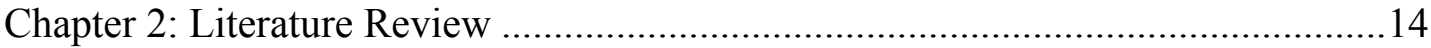

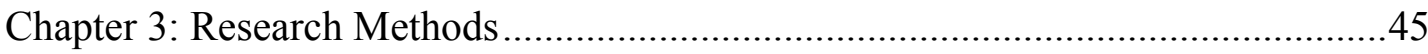

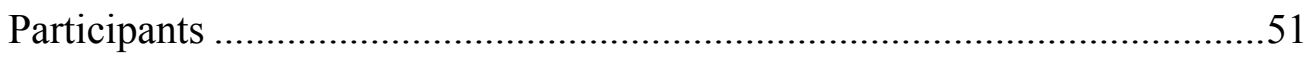

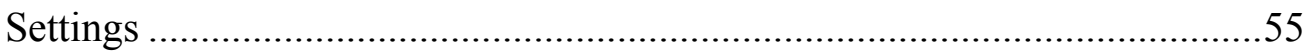

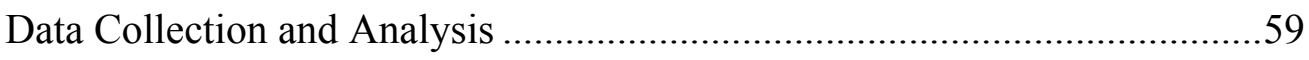

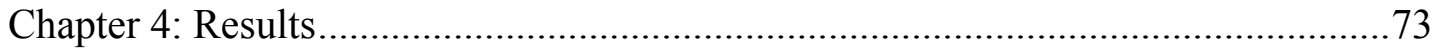

Elementary Special Education Case Study ...............................................74

Middle School Special Education Case Study ...........................................87

High School Special Education Case Study ............................................101

Comparison of Collaborative Practices Across Settings ...........................113

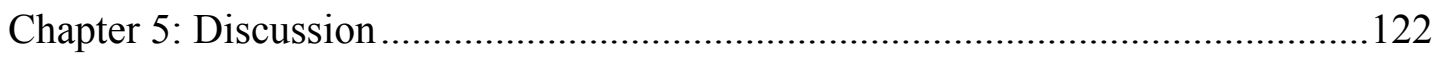

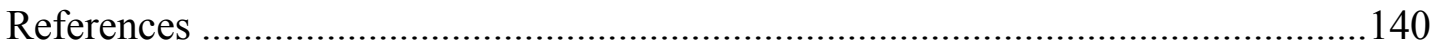

Appendices:

Appendix A. Interview Protocol...........................................................150

Appendix B. Collaborative Practices Survey and Checklist .......................152

Appendix C. Typology of Reflection Rubric ...........................................155 


\section{List of Tables}

Table 1. Collaboration Standards and Practices for Special Education 30-31

Table 2.Special Education Teacher Candidate Information ......................................52

Table 3.Special Education Mentor Teacher Information ........................................53

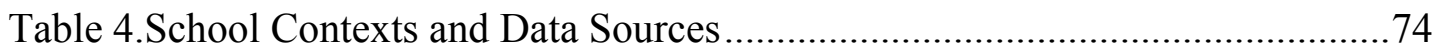

Table 5. Survey Results on Elementary Collaborative Practices ..............................76

Table 6. Interview Results of Elementary Collaboration ......................................78

Table 7. Emerging Themes from Elementary Interview ........................................79

Table 8. Elementary Participant Perspectives ................................................. 80-81

Table 9. Typology of Reflection Narratives: Elementary ......................................83

Table 10. Survey Results on Middle School Collaborative Practices .......................89

Table 11. Interview Results on Middle School Collaboration .................................90

Table 12. Emerging Themes from Middle School Interview ...................................91

Table 13. Middle School Participant Perspectives .............................................. 94-95

Table 14. Typology of Reflection Narratives: Middle School .................................97

Table 15. Survey Results on High School Collaborative Practices..........................102

Table 16. Interview Results on High School Collaboration ............................ 104-105

Table 17. Emerging Themes from High School Interview ....................................106

Table 18. High School Participant Perspectives............................................ 107-108

Table 19. Typology of Reflection Narratives: High School...................................109 


\section{List of Figures}

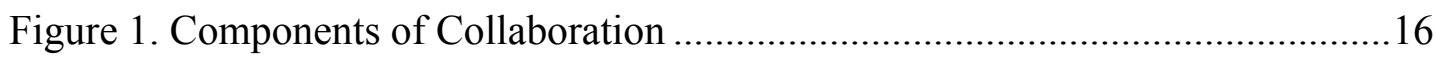

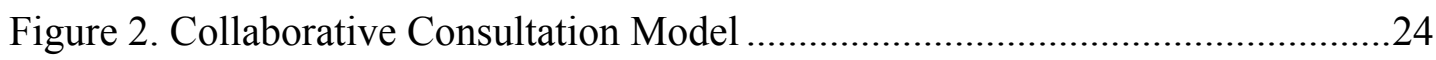

Figure 3. Embedded Multiple-Case Design for Collaboration in Schools ..................49

Figure 4. Instrument Results in Collaborative Practice Categories ..........................114

Figure 5. Mentor Teacher Results Per Collaborative Practice Category....................114

Figure 6. Teacher Candidate Results Per Collaborative Practice Category ..............115 


\section{Chapter 1}

\section{Introduction}

Collaboration has been an essential role of special education teachers, who must work with parents, teaching assistants, and other school professionals to meet the needs of students with disabilities, but the nature of collaboration between general and special education teachers is changing. In the past, special education teachers maintained an autonomous and relatively isolated existence in schools. However, now more than ever, general and special education teachers are expected to collaboratively plan curriculum and instruction for students with disabilities.

No Child Left Behind legislation (NCLB, 2001) and the reauthorization of the

Individuals with Disabilities Education Act (IDEA) in 2004 include mandates meant to strengthen the connection between general and special education curriculum, and increase opportunities for the inclusion of students with disabilities. These legislative changes are impacting the role of teachers in schools and have implications for teacher education programs and professional development for teachers. General and special education teachers need to play a joint role in the education of students with disabilities, to provide access to general education curriculum and foster the success of inclusion. 
In meeting the needs of students with disabilities, it is assumed general education teachers bring expertise of the curriculum (Brownlie \& King, 2000), and special educators bring an understanding of how disabilities impact learning, how to adapt curriculum and instruction, and how to work in small groups or with individual students (Hudson \& Glomb, 1997). However, research shows that general and special education teacher graduates report feeling unprepared for collaboration to help students be successful in an inclusive environment (Scruggs \& Mastropieri, 1996). Although much is known about strategies and skills for successful collaboration (Friend \& Cook, 2007), little is known about how general and special education teachers are being prepared in teacher education to work together in schools to ensure access to general education curriculum and classrooms (Blanton, Pugach, \& Florian, 2011).

\section{Pilot Study: Reflections on Collaboration}

Inclusion and collaboration were the focus of a pilot case study I did in 2008/2009

with a first year special education teacher. It was my intention to get both general and special education first year teachers to participate in a focus group during one year to learn with them about collaboration in their schools. Unfortunately, only one person participated in this study. This participant was a first year special education teacher who 
had no specific coursework or field experiences with collaboration or inclusion. I met with the special education teacher four times during the school year to review and discuss written reflections. I introduced reflective practice and journal writing as tools for learning and sharing about inclusion and collaboration in her school. It was my goal that through dialogue and written reflections I could learn alongside this teacher about the challenges of collaborating to meet the needs of students with disabilities in inclusive settings, from her perspective. I was interested in observing how her reflections guided her actions.

The pilot case study revealed challenges of collaboration and inclusion in schools consistent with the research such as time and conflicting priorities (Friend \& Cook, 2007). An unexpected outcome was to see how this special education teacher's beliefs about inclusion and collaboration changed over the course of the year based upon the culture and practices in the school. In the beginning of the year, she was committed to the mission and practices of inclusion and collaboration, but changed her attitude and beliefs to be consistent with a more traditional approach of separation and isolation for special education teachers and students. She came to believe that separate classrooms and teachers was the most efficient and practical way to educate students with disabilities. 
Another unexpected outcome of this study was how reflective practice was not automatic or readily adopted by her. The teacher did not participate in journal keeping, but it was evident in our discussions that she became gradually disillusioned about meeting the needs of students with disabilities in general education due to what she perceived as insufficient resources and a lack of commitment from the general education teachers.

We [special education teachers] don't really have enough time to collaborate. We sometimes talk to general education teachers but we're not really collaborating. We can't. One teacher really wanted to. She probably has about 10-15 of our students in her class. It's low level English, and she wanted to meet and collaborate, and I had to tell her we don't have time. You know, we're not given time to do that. We could meet with her but we can't go through every student with her and help her pick out curriculum. Which, you know, in the ideal world, we would love to try to advise teachers that things are going to go way over their head and they're going to lose the students. We just don't have time to really sit down and go over materials and look at things so it works better to just pull the students out of the general education classroom. (Interview, March 2008)

The barriers to collaboration captured in this interview were consistent with those described in the research (Friend \& Cook, 2007). The participant's limited time to meet and plan with general education teachers was mentioned as an obstacle to inclusion. General education teachers were reportedly not committed to collaboration, and general education teachers were viewed as not able to meet the needs of special education students. The special education teacher in this study started the year wanting to 
collaborate with general education teachers and support inclusion. She did not recognize how her perspective changed or how her perspective was shaped by the norms of the school culture. Rather than question the school practices of exclusion, think of creative solutions, or act as an agent of change, she succumbed to the status quo. It's hard to know if her thinking or actions would have been different had she engaged in reflective practices or had different preparation in teacher education. This pilot study was the impetus for further research and exploration on collaboration and reflective practices for pre-service special education teachers to prepare them to be collaborators, regardless of the school culture, lack of resources, and school leadership.

\section{Problem Statement}

Collaboration between general and special education teachers is widely recognized as being critical for successful inclusion and effective instruction to students with disabilities (Brownell, Adams, Sindelar, Waldron \& Vanhover, 2006; Jorgensen, Schuh \& Nisbet, 2006). Collaboration not only supports student achievement for students with disabilities, but promotes teacher learning (Rogers \& Babinski, 2002;

Thousand,Villa, \& Nevin, 2002), and increases feelings of competency and job satisfaction for teachers (Zahorik, 1987). However, research shows that general and 
special education teacher graduates feel unprepared for collaboration that supports inclusion in schools (Scruggs \& Mastropieri, 1996), and professional development workshops for practicing teachers in the areas of inclusion and collaboration are generally not effective in facilitating collaboration or making inclusion successful (McLesky \& Waldron, 2004). Administrative leadership is considered critical in shaping collaborative practices and an inclusive school culture among teachers (Smith \& Leonard, 2005), but such leadership is not consistent across schools. There is a general consensus that better preparation needs to happen prior to becoming a practicing teacher in the formative years of learning to be a teacher.

General and special education teachers have historically been prepared for parallel and separate roles in schools. Federal policies and standards for teacher education include changes to ensure special education teachers are no longer isolated from the broader context of education (Blanton, Pugach, \& Florian, 2011). The New Teacher Assessment and Support Consortium (INTASC, 2013) developed a common set of standards for teacher education that apply to both general and special education candidates. Eight of the ten INTASC standards include an expectation that both general and special education teacher candidates will demonstrate knowledge, dispositions, and performance in 
collaboration while in the teacher education program. Noted in the INTASC standards is, "our current system of education tends to isolate teachers and treat teaching as a private act" (p.4). In promoting a new paradigm, INTASC standards advocate for a collaborative approach to planning, teaching, and assessment.

Research shows teacher preparation programs lack coursework and field experience for preparing both general and special education candidates for inclusion and collaboration (McKenzie, 2009; Harvey, Yssel, Bauserman, \& Merbler, 2010). The National Center for Special Education Personnel and Related Service Providers report that only $30 \%$ of the programs that grant Bachelor's or Master's degrees for special education prepare them to be collaborative and consultative special educators (NASDSE, 2010). Students with special needs continue to be served in resource rooms or through pull-out programs (U.S. Department of Education, 2002). The current ethos in education reform related to meeting the needs of diverse students is to start preparing teachers for collaboration in teacher education to minimize the removal of students from access to the general education curriculum and classroom, and support more inclusion and collaboration in schools. 
As a faculty member and evaluator of special education teacher candidates, it became apparent to me that more information is needed on the nature and extent of collaboration in field placements to make program revisions that are aligned with the new collaborative roles of special education teachers (Friend \& Cook, 2010), policy related to students with special needs (NCLB, 2001), and standards for teacher education (INTASC, 2013). There is a lack of research on preparing teachers for both inclusion and collaboration in teacher education (Friend \& Cook, 2010), and a lack of guidance from the Committee on Teacher Education (CTE) on these areas for accreditation and program performance (Le Page, Courey, Fearn, Benson, Cook, Hartmann, \& Nielson, 2010). In addition, there is a noted lack of research and a call for more overall accountability in special education teacher preparation (Brownell, Ross, Colon, \& McCallum, 2005).

The focus of this research was to understand the extent to which special education teacher candidates experienced collaboration with general education teachers to plan and coordinate instruction for students with disabilities, and to understand how field placements are shaping their perspective on the role of special education teachers in collaborating with general education teachers. Outcomes of this research are recommendations for program revision and policy change that are consistent with 
research and teacher education standards that support stronger collaboration between special and general education teachers.

\section{Research questions.}

1. To what extent are special education teacher candidates expected to collaborate with general education teachers during student teaching?

2. How are perspectives on collaboration with general education teachers different between special education teacher candidates and their mentor teachers?

\section{Theoretical Framework}

The following theoretical framework helps to describe preconceived notions about the complexity of learning about collaboration as a special education teacher candidate. As a guest and mentee in classrooms, special education teacher candidates learn by observing, listening, and practicing skills in relation to teaching. There are limits to what they can do and experience based on opportunities available in a particular classroom environment. Lave and Wenger (1991) introduced the concept of legitimate peripheral participation to describe how membership or access in a community occurs through apprenticeships. Individuals adapt to the environment and the environment shapes learning. Content learned depends on a reciprocal relationship between the 
environment and the individual. Within that experience, learning occurs through observations and communication, as messages are sent, received and interpreted. Student teaching is considered a type of apprenticeship. Special education teacher candidates are learning how to be professional special education teachers from their mentor teachers in a variety of special education settings.

Driscoll (2000) asserts that learning cannot be separated from the contexts in which the learning takes place. Learning happens in the mind of the individual but always in relation to others, under the influence of environments and situations. The context of learning is mediated by the ideas and thoughts of others in a community of practice (Lave $\&$ Wenger, 1991). Situated at the periphery of communities, participants are not full members, but are learning about the culture of the group and norms of membership by observing. As they become increasingly competent, they gain membership to the community through their evolving and incremental participation.

Collaboration in schools is complex, involving factors that are personal or internal, and it is impacted by factors that are external or situational. Personal or internal factors of successful collaboration include trust, relationships, and routine communication (Friend \& Cook, 2007), all of which take time to establish. Learning 
about collaboration is limited in practice for special education teacher candidates as guests in schools and classrooms. They are not full members of the school community, and therefore not in a position to build collaborative relationships with general education teachers. Special education teacher candidates must learn about collaboration from the periphery. Their role in collaboration will be more aligned with what Hargreaves (1994) refers to as contrived collegiality, as opposed to active participants in collaborative practice-based problem solving. However, what they can do from the periphery is to observe the collaborative practices of the group, and to reflect and learn. They need tools to interpret what they are observing, and a framework for maintaining principles of collaborative practice to transcend rather than perpetuate barriers.

Communication theories describe how values, ideology, symbolism, language, power, and communication styles impact how messages are delivered and received. Communication is described by Griffin (2012) as "the relational process of creating and interpreting messages that elicit a response" (p. 6). Culture is produced and reproduced by systems of communication. What and how teachers communicate not only shapes their relationships, but also reflects perspectives of the self and the context. Historically, the cultural divide between general and special education teachers is represented in the 
language used to identify students as mine and yours, depending on whether the student has a disability. The implied meaning is that students with disabilities are the responsibility of special education teachers. As an apprentice in schools, special education teacher candidates construct meaning from the culture and language that surrounds them, which in turn contributes to their perception of their future role as special education teachers. As a culture, we prescribe meaning to words and symbols by naming what we know. "Humans act toward people or things on the basis of the meanings they assign to those people or things" (Griffin, 2012, p. 56). General and special education teachers have preconceived perspectives of one another and of students with disabilities based on their personal and preparatory experiences, and the culture of the schools in which they work.

Critical theory is a framework that focuses on the unfair distribution of social power, ideologies perpetuated by dominant groups, and the oppression of marginalized groups (Freire, 2006). Both general and special education teachers may have a selfinterest in maintaining the prevailing school structures and in promoting ideologies that justify the privilege to move a difficult student out of a general education classroom and assigning responsibility for students that are difficult to special education classrooms and 
teachers. Inclusion and collaboration demand a level of caring and recognition of

challenges posed by power and territory, over personal goals and established routines,

which are important to recognize and be aware of.

For teachers to assume new, expanded roles and engage in effective collaboration

that supports the inclusion of students with special needs, tools are needed to support

learning, thinking, leadership, and teaching. Strategies for collaboration are important,

but not necessarily effective in leading to positive change unless teachers can recognize

biases and attitudes toward disability and inclusion, and look at values, practices, and

structures that reinforce exclusion. Special education teacher candidates need to be part

of an evolution in schools toward a change in practices from laboring independently in

individual classrooms to working as part of a the broader team of teachers. These theories

have implications for understanding how special education candidates might learn about

collaboration on the periphery, and critically interpret experiences in schools to maintain

a commitment to collaboration regardless of the school culture. 
Chapter 2

\section{Literature Review}

This literature review will describe components of collaboration, and research on the preparation of special education candidates for collaboration in schools. In particular, this literature review will focus on the skills and dispositions that individual special education teachers need to foster and sustain collaborative practices. A teacher's position on collaboration is influenced by contextual factors embedded in the school culture and leadership (Smith \& Leonard, 2005). As described in the pilot study at the beginning of this paper, teachers conform to roles as they assimilate to the culture of the school. Preparing teachers to transcend traditional barriers of practice and philosophy involves preparing them to look critically at the context and see themselves as not only capable of influencing positive change, but morally responsible to act (Zeichner \& Liston, 1996). Fullan (2006) advocates for empowering teachers with tools to be agents of change and contribute to effectiveness in schools. This literature review will explore components of collaboration, and ways pre-service teachers can develop the capacity to be leaders in schools for collaborative practices. 


\section{Collaboration Defined}

Friend and Cook (1992) describe collaboration in the context of schools as an

"interpersonal style of direct interaction between at least two co-equal parties voluntarily engaged in shared decision making as they work toward a common goal" (p. 5).

Interpersonal style is described as important for opening dialogue and essentially getting the foot in the door for collaboration to start happening, and maintaining collaboration over time with a variety of individuals. Friend and Cook (2007) believe making collaboration voluntary is important for guaranteeing that individuals will participate in the process by choice, and therefore be more likely to have a positive attitude toward collaboration. Mutually agreed upon goals should be clearly defined and in the best interest of students. An assumption in this overall definition is a foundation of parity, meaning collaboration between general and special education teachers begins with a perception of equal power in decision-making. The act of collaboration involves coming together, working together, and sustaining relationships. As Friend and Cook (2007) point out, mutual trust and respect are essential for relationships to flourish.

Collaborative teaming is a term that connotes the process of collaboration as interactive and dynamic. Knackendoffel, Robinson, Deshler, and Schumaker (1992) 
describe collaborative teaming as an ongoing process whereby educators with different areas of expertise work together voluntarily to create solutions to problems that are impeding students' successes. This definition focuses on the overarching goal of collaboration in schools, which is to support students. In reality, collaboration is complex, involving constant negotiation, compromise, and communication with different people and in different settings.

Friend and Cook (2007) developed a framework to reflect the complexity of collaboration in schools to include five components that are interrelated (Figure 1) to include personal commitment, communication skills, interaction processes, programs and services, and the school context.

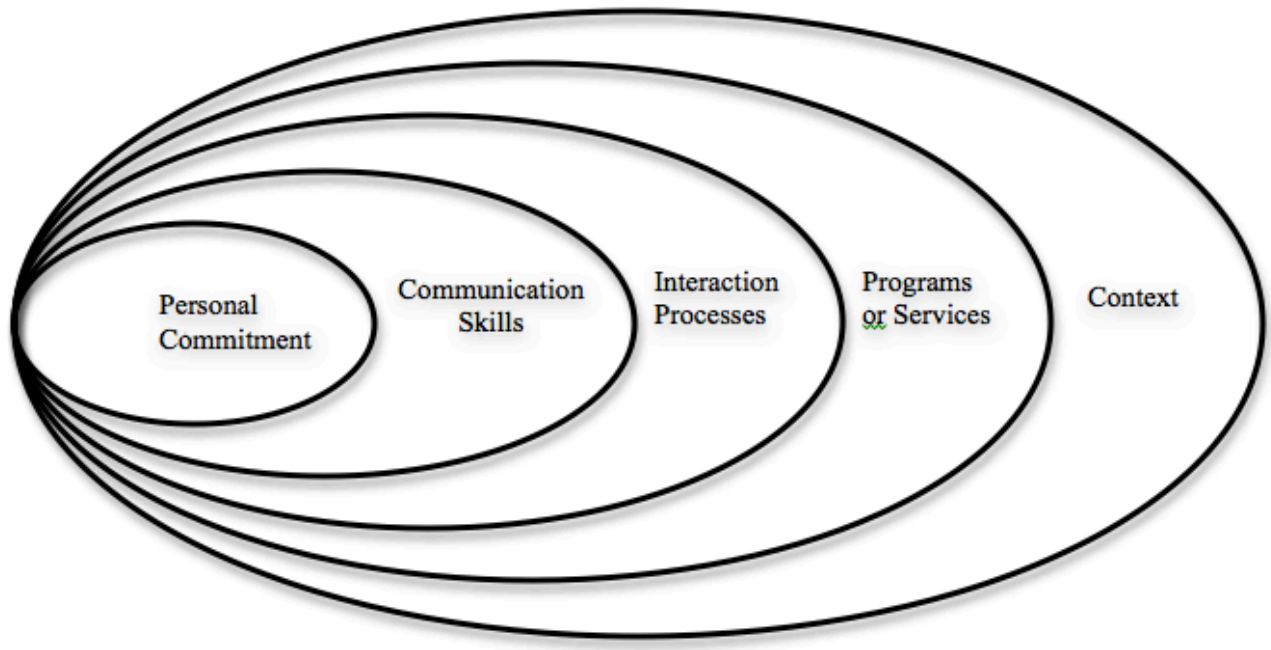

Figure 1. Components of collaboration. Source: Friend and Cook (2007). 
Personal commitment includes beliefs, values, perspectives, and guiding principles important for collaborating with others. Communication skills include interactions that are interpersonal (in relation to others) and intrapersonal (selfregulatory), including styles and strategies for sending and receiving messages, listening skills, nonverbal communication, and conflict resolution. Interaction processes are steps taken for problem solving and conflict resolution. Programs and services include the variety of ways collaboration is practiced when designing and delivering instruction for students. The context is the environments in which collaboration occurs. This framework shows how collaboration is a dynamic process within the school system, which starts with individual beliefs and commitment at the core. Each component of collaboration has implications for preparing special education teachers, and will be explored in more detail.

Personal commitment. The director of the Institution on Disability, Jan Nisbet (2004) wrote, "Children in self-contained classrooms do not move to inclusive educational environments, not because of lack of ability, but because of structural belief systems that exist within organizations - that is, some students belong and some do not" (p.234). Positive attitudes toward collaboration, and beliefs about whether or not the 
academic needs of students with disabilities can be met in general education classrooms are essential for collaboration to be successful (Silverman, 2007).

A traditional perspective related to special education is a belief that the unique and individual needs of students with disabilities can only be adequately addressed by special education teachers who have specific skills and knowledge for educating students with disabilities (Fisher, Frey \& Thousand, 2003). Within this perspective, special education teachers are the experts with this population, and general education teachers are not capable of meeting the needs of students with disabilities. Research shows that special education teachers often believe that general education teachers do not have the skills or knowledge to meet the unique needs of students with disabilities (Jordan, Schwartz, \& McGhie-Richmond, 2009), and that general education teachers are often reluctant to take responsibility for students with disabilities in their classroom (Buell, Hallam, \& Gamel-McCormick, 1999; Soodak \& Podell, 1994).

Rocco (2006) notes that a deficit perspective is an outcome of the medical model, where disability is viewed as an illness among a society that strives to be optimal in health, mind, and body. An orientation on individual deficits isolates students based on what they can and can't do, but also isolates teachers from one another. "Those students" 
are perceived to need the expertise and attention of those teachers, namely special education teachers, and the culture of isolation leads to competing priorities that make collaboration difficult to establish and maintain (Reinhiller, 1999). Robinson and Riddle Buly (2007) point out that separate cultures exist between general and special education teachers, creating a two-track system, with beliefs about education falling into completely different paradigms, including a different research base, epistemology, and perceived responsibilities.

Stanovich and Jordan (2002) found that special education teachers who followed a deficit model for disability made consistent attempts to keep students with disabilities excluded, but if they viewed disability as a developmental challenge that could be improved through effective teaching they were more likely to be open to collaboration. A significant shift in thinking and practice must occur so that people can move from a traditional model of special education teachers being isolated and independent to valuing the benefits of collaborative planning and problem solving. Cook \& Schirmer (2006) identify five perspectives found to be conducive to effective collaboration including:

1. Recognizing that inclusion is complex and requires joint and sustained effort

2. Acknowledging the creativity generated by working collaboratively by combining the effectiveness of teachers skilled in content and curriculum with skills in adaptations and special education processes 
3. Participating willingly in joint problem solving by welcoming the personal and professional support of colleagues

4. Recognizing and valuing the personal learning and growth that results from collaboration

5. Reflecting about personal educational practices by evaluating own teaching competencies and looking for ways to be more effective in teaching and collaboration

Communication skills. Central to communication theory (Griffin, 2012) is how people make meaning together through social interaction, and how those interactions shape perspectives of individuals and relationships. Patterns of interaction and ways of communicating are critical for building relationships, both through person-to-person conversations and through other mediums. Communication theory points out that interpretation of messages are different for everyone, and it is important to be aware of and reflect upon the context and the perspective of others (Griffin, 2012).

Interpersonal communication skills for collaboration are described by Friend and Cook (2007) as the ability to engage in transactional communication, where messages can be conveyed across multiple channels, with awareness and sensitivity of frames of reference of oneself and those of others depending on experiences and culture. As stated, "Effective communication is characterized by openness, meaningfulness, effective use of silence, and an ability to adapt communication to meet the needs of the task and the relationship" (Friend \& Cook, 2007, p. 232). Intrapersonal communication skills are 
described as internal conflicts or dilemma that have an effect on a relationship.

Intrapersonal communication skills include the ability to engage in proactive problem solving and conflict resolution, while maintaining the integrity of a relationship.

Interaction processes. Interactions are the building blocks to successful collaboration, and depend upon the quality of relationships. Individuals can be at different degrees of readiness for basic communication, developing goals, and finding solutions depending upon intrapersonal and interpersonal communication skills and experiences. "Teachers need to know how to raise questions in a professional manner, seek appropriate information about student performance and school practices, and bring that information to the table for discussion and take action" (Le Page, Courey, Fearn, Benson, Cook, Hartmann, \& Nielson, 2010, p. 30). Reaching a common goal can involve conflict, and many teachers are not comfortable or know how to manage conflict. Johnson and Johnson (1994) point out that conflict is not necessarily negative, and is an inherent part of problem solving and collaboration. Negative and detrimental aspects of collaboration are attitudes toward conflict and processes for problem solving. If a member of the group is uncomfortable with brainstorming and there are differences in opinion, then collaboration will typically be avoided. 
One of the most important courses of action when there is conflict includes understanding differences and reacting in ways that are open and not destructive to relationships (Creamer, 2004). Friend and Cook (2007) recommend understanding personal conflict response styles to recognize different ways of resolving conflict to include: competitive, avoidance, accommodating, compromising, and collaborative styles. A competitive style is goal-oriented and focused on winning. Second, an avoidance style avoids tension and allows others to solve problems. Third, an accommodating style focuses on preserving the relationship and having agreement. Fourth, a compromising style reaches for middle ground. Finally, a collaborating style encourages the sharing of ideas and working through differences to reach a solution. When understanding why another teacher might be resistant to collaboration, it is important to recognize communication and conflict response styles, but also to understand steps in problem solving (Cook, 2007), and recognize that there are different degrees of readiness, and that some teachers may fear change.

Programs or services. Current research on collaboration in schools supports a collaborative-consultation approach between teachers rather than an expert model of consultation (Dertmer, Thurston, \& Dyck, 2002). In collaboration, all participants bring 
knowledge and expertise in their areas to contribute valuable insights to discussing and achieving a goal. Collaborative consultation recognizes the variety of roles that can lead to effective problem-solving toward a common goal when there are differences in knowledge, levels of expertise, and commitment (Friend \& Cook, 2007).

Figure 2 shows that within the collaborative consultation model, teachers alternate roles depending on the stage of the relationship and the information that needs to be conveyed or discussed to include conversation, coaching, consultation, and collaboration (Lipton \& Wellman, 2007). The recommendation is that teachers are able to have periodic conversations that are unfocused, low risk, and without a central purpose, just to develop camaraderie. Coaching is important for having open-ended conversations around a topic such as reading instruction. During coaching, it is assumed that teachers share a level of technical knowledge. If teachers don't share technical knowledge on a topic and one teacher knows more information than the other, the relationship moves to one of consultation. Collaboration would be a reciprocal exchange of expertise, ideas, analysis, information and accountability, in this case related specifically to a student, with the development of clear goals and a plan of action. Collaborative consultation is a practice that allows for a range of interactions, from informal and friendly to professional 
and focused, with a variety of school colleagues. This is particularly important for special education teachers because they need to include themselves among the rest of the faculty in a variety of ways for a variety of reasons to build relationships and foster a collaborative culture. Skills in implementing a framework of collaborative consultation are essential for special education teachers who must prepare for a growing demand to participate in collaboration and co-teaching (Austin, 2001; Fennick \& Liddy, 2001).

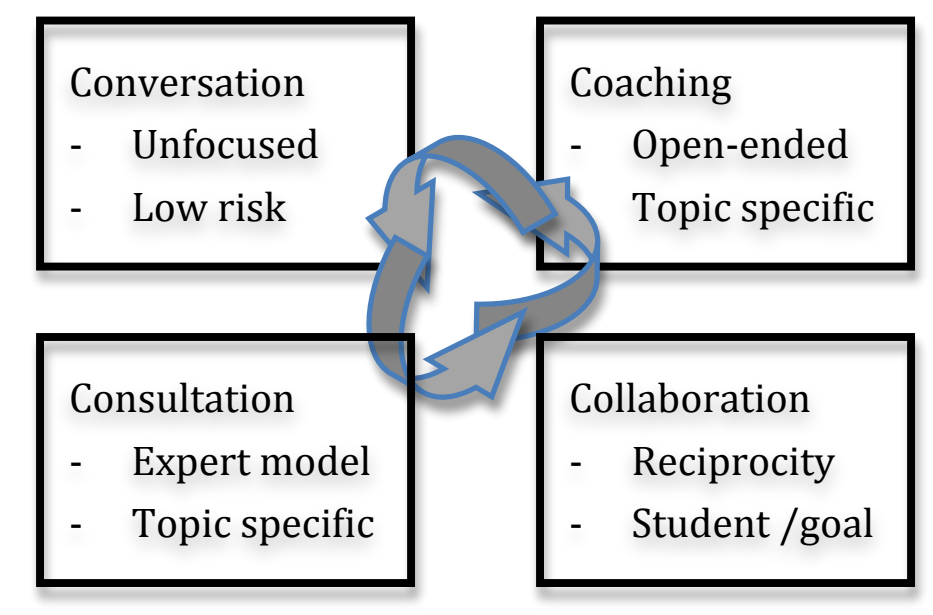

Figure 2. Collaborative consultation model. Source: Lipton \& Wellman (2007).

Co-teaching occurs when teachers jointly plan, implement, and evaluate instruction together in a shared setting for a specific amount of time on a consistent basis (Friend \& Cook, 2010). The role of the general education teacher in a co-teaching model is as content specialist, and the role of the special education teacher is as the strategic 
teacher of specialized services (Friend \& Cook, 2010; Snell \& Janney, 2005). Co-

teaching can be further clarified as either a role exchange or content and skill

development. In a role exchange, each teacher assumes responsibilities for the delivery of instruction. In content and skill development, the general education teacher is responsible for and provides instruction on the content. The special education, or strategic teacher, is responsible for and provides instructional strategies (e.g. re-teaching, reinforcing, or restating instruction) to enhance learning and connections to content. Friend and Bursuck (2002) describe a variety of instructional and classroom arrangements that general and special education teachers can use in a co-teaching model to include:

1. Lead one / Support one: One teacher teaches and the other observes / collects data, etc.

2. Station Teaching: Instruction divided into segments or steps to be completed at each station

3. Parallel Teaching: Same lesson delivered simultaneously by both teachers to different groups

4. Alternative Teaching: Small group for specialized skills while larger group with lead teacher

5. Team Teaching:

a. Speak and Add: Instruction delivered together / reciprocal conversation

b. Speak and Chart: Instruction delivered together / speaker and writer or media support

6. Shadow Teaching: A lead teacher teaches and the other teacher that circulates

7. Skill Groups: Each teacher responsible for specific groups of students working on particular skills 
Rea, McLaughlin, and Walther-Thomas (2011) found that students with

disabilities had better attendance and performed better academically in classes that were co-taught. Critical factors for successful co-teaching include the special education teachers having the knowledge and skill for making modifications and accommodations to the general education curriculum (Hoover \& Patton, 2004), implementing cooperative learning strategies (Johnson \& Johnson, 1994; Deshler \& Schumaker, 1986), differentiating instruction (Soodak, Podell and Lehman, 1998), forming flexible groups (Soodak, et al, 1998), and utilizing peer tutors (Smith \& Leonard, 2005). Teachers with high self-efficacy are shown to be significantly more willing to adapt curriculum and instruction for students with disabilities, and to be more patient and flexible in providing these students with extra help (Cook, Tankersley, Cook, Landrum, 2000; Fisher, Frey, \& Thousand, 2003).

Barriers to collaboration and co-teaching include limited time for planning (Kohler-Evans, 2006), low sense of efficacy (Shippen, Crites, Houchins, Ramsey, \& Simon, 2005; Harvey, et. al 2010), lack of commitment and skills in communication and problem solving (Gerber \& Popp, 2000), and conflicting priorities (Pugach \& Warger, 1996). Silverman (2007) points out that positive experiences with collaboration and co- 
teaching can help general and special education teachers develop positive attitudes and skills, which can lead to a continued commitment to these practices.

Collaboration and school context. Embracing a value-based practice around inclusion and collaboration involves taking a critical look at biases and attitudes toward disability, collaboration, inclusion, as well as looking at values, practices, and structures that reinforce teacher isolation and exclusion. Smith and Leonard (2005) note the same accountability mandates that promote collaboration can also be counterproductive for collaboration and inclusion. These mandates hold teachers and school administrators accountable for student achievement, which can discourage teachers and principals from inclusion, and reinforce the exclusion of students with disabilities to improve efficiency in achieving outcomes.

Successful collaboration in schools depends upon the perspective that all students belong, and all teachers are responsible for all students. However, research shows that a primary factor in the success of inclusion and collaboration is administrative leadership. Principals and administrators influence school culture and allocate time and resources (Friend \& Cook, 2007; Smith \& Leonard, 2005). Administrators can support teacher collaboration by supervising in classrooms, providing early dismissal, or using 
professional development opportunities to learn about collaboration (Bos \&Vaughn, 2002). However, many schools do not have such leadership in place. This is out of the control of the special education teacher candidates. Therefore, finding schools and mentor teachers who provide good models of collaboration and inclusion is not always possible. Special education teacher candidates need to understand theories of collaborative practice, to reflect on their experience in relation to what they have learned in the teacher education program, and be prepared to enter schools with the capacity and commitment to collaborate as professionals for the benefit of students, regardless of the context.

To be a teacher leader or agent of change promoting a collaborative and inclusive school culture despite the context, teachers need to be able to transform traditional roles and functions, have a positive disposition about collaboration and what students with disabilities can achieve in school, have the knowledge and skills for adapting curriculum and instruction, and be reflective to learn from experiences (Villa, et. al. 1996).

\section{Teacher education standards for special education}

Special education teachers face many challenges that differ from general

education teachers, particularly related to collaboration (Friend \& Cook, 2010). As case 
managers, curriculum planners, facilitators, instructors, and organizers of individualized education plans, they need to collaborate with a variety of adults (e.g., general educators, administrators, educational assistants, and parents). The scope of special education teacher responsibilities as case managers and strategists for students with disabilities across grades makes them key players in fostering collaboration with general education teachers.

The Council for Exceptional Children (CEC) has established standards for the field of special education (CEC, 2009). These standards serve as benchmarks for state teaching license standards, teacher education programs, and continuing professional development. CEC identifies knowledge and skills for entry-level and advanced special educators in a common core, and a variety of specialty areas, including collaboration. CEC standards have been accepted as the professional standards for special education (NCATE, 2002). In the state of Oregon, the Teacher Standards and Practices Commission (TSPC) licensing board includes recommendations for special education teacher preparation based on CEC standards that are incorporated into program curriculum and assessment of candidates. Table 1 outlines the collaborative role of special education teachers based on CEC standards, guidelines for preparation and licensure by TSPC, and 
practices identified as essential skills for special education collaborative practices as

outlined by Friend and Cook (2007).

Table 1

Collaboration Standards and Practices for Special Education Teachers

\begin{tabular}{|c|c|}
\hline $\begin{array}{l}\text { CEC (2009) } \\
\text { Standard } 10 \text { in } \\
\text { Collaboration } \\
\text { Specialization } \\
\text { for Initial } \\
\text { Licensure in } \\
\text { Content and } \\
\text { Curriculum. }\end{array}$ & $\begin{array}{l}\text { Knowledge of: } \\
\text { 1. Models and strategies of consultation and collaboration } \\
\text { 2. Roles of individuals with exceptional learning needs, families, and school and } \\
\text { community personnel in planning of an individualized program } \\
\text { 3. Concerns of families of individuals with exceptional learning needs and } \\
\text { strategies to help address these concerns } \\
\text { 4. Culturally responsive factors that promote effective communication and } \\
\text { collaboration with individuals with exceptional learning needs, families, } \\
\text { school personnel, and community members } \\
\text { Skills in: } \\
\text { 1. Maintain confidential communication about individuals with exceptional } \\
\text { learning needs } \\
\text { 2. Collaborate with families and others in assessment of individuals with } \\
\text { exceptional learning needs } \\
\text { 3. Foster respectful and beneficial relationships between families and } \\
\text { professionals } \\
\text { 4. Assist individuals with exceptional learning needs and their families in } \\
\text { becoming active participants in the educational team } \\
\text { 5. Plan and conduct collaborative conferences with individuals with exceptional } \\
\text { learning needs and their families } \\
\text { 6. Collaborate with school personnel and community members in integrating } \\
\text { individuals with exceptional learning needs into various settings } \\
\text { 7. Use group problem-solving skills to develop, implement and evaluate } \\
\text { collaborative activities } \\
\text { 8. Model techniques and coach others in the use of instructional methods and } \\
\text { accommodations } \\
\text { 9. Communicate with school personnel about the characteristics and needs of } \\
\text { individuals with exceptional learning needs } \\
\text { 10. Communicate effectively with families of individuals with exceptional } \\
\text { learning needs from diverse backgrounds } \\
\text { 11. Observe, evaluate and provide feedback to education assistants } \\
\text { ald }\end{array}$ \\
\hline
\end{tabular}


Table 1. (continued)

\begin{tabular}{|c|c|}
\hline $\begin{array}{l}\text { Collaborative } \\
\text { Practices for } \\
\text { Special } \\
\text { Education } \\
\text { Teachers (Friend } \\
\text { \& Cook, 2007) }\end{array}$ & $\begin{array}{l}\text { - Include the general education teacher as an equal partner in the planning, } \\
\text { delivery, and assessment of learning } \\
\text { - } \\
\text { Identify and communicate adaptations for instructional methods and materials } \\
\text { to general education teachers. (ICC10S8) } \\
\text { - Ensure that general education teachers have a copy of the IEP } \\
\text { - Coordinate participation of general education teachers in Individualized } \\
\text { Education Plan } \\
\text { - Include instructional assistants in collaborative plans. (ICC10S11) } \\
\text { - } \quad \text { Observe students with disabilities in the general education setting (ICC10S6) } \\
\text { - Conduct assessments with general education input and feedback as needed } \\
\text { (ICC10S2) } \\
\text { - Coordinate ongoing meetings and progress monitoring with general education } \\
\text { - } \quad \text { Provere } \\
\text { - to teachers and educational assistants, and school staff. (ICC10S9) } \\
\text { - Co-teach or team teach with general educators } \\
\text { Collaborative problem solving with general education teachers (ICC10S7) }\end{array}$ \\
\hline $\begin{array}{l}\text { Teachers } \\
\text { Standards and } \\
\text { Practices } \\
\text { Commission } \\
\text { (TSPC, 2013) } \\
\text { Oregon } \\
\text { Administrative } \\
\text { Rule } \\
\text { 584-065-0035 } \\
\text { Knowledge, } \\
\text { Skills and } \\
\text { Abilities for } \\
\text { Special } \\
\text { Education } \\
\text { Endorsement }\end{array}$ & $\begin{array}{l}\text { (j) Standard 10: Collaboration. } \\
\text { Candidates routinely and effectively collaborate with families, other educators, related } \\
\text { service providers, and personnel from community agencies in culturally responsive } \\
\text { ways. This collaboration assures that the needs of individuals with exceptional } \\
\text { learning needs are addressed throughout schooling. Candidates: } \\
\text { (A) Embrace their special role as advocate for individuals with exceptional learning } \\
\text { needs; } \\
\text { (B) Promote and advocate the learning and well being of individuals with exceptional } \\
\text { learning needs across a wide range of settings and a range of different learning } \\
\text { experiences; } \\
\text { (C) Are viewed as specialists by a myriad of people who actively seek their } \\
\text { collaboration to effectively include and teach individuals with exceptional learning } \\
\text { needs; } \\
\text { (D) Are a resource to their colleagues in understanding the laws and policies relevant } \\
\text { to Individuals with exceptional learning needs; and } \\
\text { (E) Use collaboration to facilitate the successful transitions of individuals with } \\
\text { exceptional learning needs across settings and services. }\end{array}$ \\
\hline
\end{tabular}

When comparing CEC standards with the collaborative practices for special

educators put forward by Friend and Cook (2007), there is overlap in six of the eleven

collaborative practices. CEC standards address collaboration with families, and have an

indicator for respectful communication, which are essential aspects of being a special 
education teacher, but are not performances included in the collaborative practices. The collaborative practices outlined by Friend and Cook are specific to working directly with general education teachers, while CEC standards are more broad in application. An example is CEC indicator 8 of standard 10 states modeling techniques and coaching others in adaptations, which could include instructional assistants or other professionals. The collaborative practices of Friend and Cook specifically target collaboration with general education teachers.

The role of the special education teacher reflected CEC standards appears to reflect a more traditional role of the special education teacher as a consultant, positioning them as experts rather than as equal partners in shared decision making. The TSPC standards also reflect a more traditional role of special educators as specialists, facilitating special education in a variety of environments, and collaborating with a variety of professionals and families. Although this specialization is important for students with disabilities, the collaboration skills of parity, problem solving, and collaborative teaming for inclusion are not evident in the CEC and TSPC standards. 
Schools that strive to include all students have special education teachers in an active role, engaged in ongoing collaboration with general education teachers to support students with disabilities in general education classrooms (Smith and Leonard, 2005). The CEC and TSPC standards do not include an indicator specific to collaboration in planning and instruction to access general education curriculum as a role of the special education teacher. Although it states an expectation for planning collaborative conferences, and modeling techniques and coaching others, it is not clear that special education candidates work with general education teachers. Oregon Administrative Rules, which guide TSPC standards for licensure, so stipulate the following under special education endorsement authorization field experience:

Candidates [must] progress through a series of developmentally sequenced field experiences for the full range of ages, types and levels of abilities (mild, moderate and severe), and collaborative opportunities that are appropriate to the license or roles for which they are preparing. (TSPC 584-065-0035, 3(a))

What is lacking is specificity about what experiences would best prepare special education teacher candidates to collaborate with general education teachers to support students with disabilities in order to guide preparation of candidates for this role.

At a glance, the collaborative practices are consistent with CEC standards, but provide more specific actions that could be used to prepare candidates for inclusive 
schools and classrooms. Preparing special education teachers to have an orientation toward inclusion and to create a culture of collaboration involves extending the vision of the role of special education teachers beyond the CEC standards. INTASC standards for teacher education have been recently revised, and now emphasize that all teachers need to be prepared to collaborate to meet the needs of all learners (INTASC, 2013). Teacher education programs and state licensing boards will need to make revisions to align expectations of course content and field-based experiences with these standards, to include preparation for collaboration for both general and special education teachers.

\section{Special Education Teacher Preparation for Collaboration}

National Council for Accreditation of Teacher Education (NCATE, 2008) expects accredited institutions to ensure new teachers have the knowledge, skills, and dispositions to collaborate, create a supportive learning environment, teach a diverse community of learners, and engage in reflective practice. In addition, the New Teacher Assessment and Support Consortium (INTASC, 2013) developed a common set of standards for teacher education that apply to both general and special education candidates. Eight of the ten INTASC standards include an expectation that both general and special education teacher candidates will demonstrate knowledge, dispositions, and performance in collaboration 
while in the teacher education program. The INTASC (2013) standards note, "our current system of education tends to isolate teachers and treat teaching as a private act" (p.4). In promoting a new paradigm, INTASC standards advocate that teachers practice a collaborative approach to planning, teaching, and assessment.

However, research shows that collaboration is not sufficiently addressed in teacher education programs (Shippen, Crites, Houchins, Ramsey, and Simon, 2005). Teacher preparation programs lack coursework and field experience for preparing both general and special education candidates for inclusion and collaboration (Harvey, et al 2010; Ramsey \& Simon, 2005). In response to recent changes in policy and standards, teacher education programs are encouraged to reinvigorate curriculum and instruction to meet the new demands of both general and special education teachers to provide a quality education for all students (Blanton, Pugach, \& Florian, 2011).

An extensive review of the literature, drawing from 16 years of research in the Supportive Effective Teacher (SET) program (Jordan, Schwart and McGhie-Richmond, 2009), concludes that the difference between effective and ineffective inclusion and collaboration depends upon skills for collaboration, teachers' beliefs about who holds the primary responsibility for students with special needs, and skills for collaborating and 
teaching diverse learners. Many general and special education teacher education programs provide coursework related to exceptionalities, but there is a lack of coursework and field experiences specifically in the area of collaboration (Harvey, Yssel, Bauserman, \& Merbler, 2010; Shippen, Crites, Houchins, Ramsey, \& Simon, 2005). Welch and Brownell (2002) found that many teacher education programs don't have a course devoted solely to collaboration. Griffin, Jones, and Kilgore (2006) found that less than one half of all special educators and less than one third of general educators received exposure to content related to collaboration within their pre-service education.

Program revisions are happening in teacher education to merge general and special education preparation, or create courses that target inclusion and collaboration with positive results. Arthaud, Aram, Breck, Doelling, and Bushrow (2007) found improved dispositions and feelings of preparedness following seminars that combined general and special education teacher candidates, using role-playing to support the development of collaboration skills. Wasburn-Moses (2009), found that special education teacher candidates learned about the importance of collaboration and co-teaching as the content was embedded in their teacher education program, but content was not observed or practiced in field experiences. The study found a discrepancy between what special 
education teachers envisioned as their collaborative role in schools based on what they learned in courses, and what they observed in schools.

The lack of connection between theory and practice is believed to contribute to the reasons new teachers lose what was learned in teacher education to fit into existing school cultures (Darling-Hammond, 2006), as was the case in the pilot study described at the beginning of this paper. Voltz and Elliot (1997) conducted a national survey of faculty in teacher education to measure faculty perspectives of actual and ideal emphases regarding preparation of general and special education teachers for collaboration and inclusion in schools. The study found a significant discrepancy between the actual preparation provided by programs and what faculty would consider ideal preparation for collaborative teaching and planning. Faculty felt there was a significant lack of preparation for collaboration, and many believed the lack of flexibility in changing course structures was a barrier to change. Voltz and Elliot (1997) stressed the importance of general and special education faculty working closely together to prepare pre-service teachers to be effective collaborators through common introductory courses, collaborative assignments, and fieldwork. 
Friend (2000) points out that many people are under the misconception that collaboration is natural and comes easily to those who want to collaborate. In fact, collaboration does not come naturally for everyone, and research shows that skills for communication and collaboration do not develop in the context of schools as needed, or as a result of having general and special education candidates in courses together, but rather need to be explicitly taught (Brownell, et al., 2006). Both providing coursework in collaboration and connecting content to field placements allows concepts learned in courses to be applied, where special education teacher candidates are supported by special education mentor teachers and university supervisors (Kilgore et al, 2003).

Preparing special education teachers is not only about preparing them for new roles and responsibilities founded on principles of collaboration and inclusion, but is also about helping them retain these principles in school cultures that maintain traditional practices of separate systems of education. Linton (1998) suggests that what's missing in teacher education is an "epistemology of inclusion.... as a broad based body of knowledge, an intellectual rationale for the incorporation of disabled people as full and equal members of society" (p. 135). Teacher education programs in the United States have maintained separate faculty, curriculum, field experiences, and license standards for 
the different disciplines and population of students those with disabilities and those without (McLeskey, \& Langley, 2011; Pugach, Blanton \& Correa, 2009). The separation of general and special education preparation parallels the philosophical, epistemological, and pedagogical division in schools (Kalyanpur \& Harry, 1999). Shippen et al. (2005) concluded in their study that dual training in general and special education may produce educators who are more willing and more capable to teach students with diverse learning needs. Research shows that teacher education programs need to do more to prepare teachers for collaboration and inclusion (Blanton, Pugach, \& Florian, 2011). Dingle, Falvey, Givner, and Haager (2004) comment, “As general and special education teachers share responsibility for educating students with disabilities, teacher preparation programs must include the knowledge and skills needed by both of these groups of teachers." (p. 36).

Much of the research on preparing pre-service teachers for collaboration in teacher education has involved surveys on the attitudes and perspectives of both general and special education candidates regarding preparation for collaboration and inclusion. There are very few studies on the preparation of only special education candidates, as most recognize the interrelatedness of collaborative practices and the need to integrate 
curriculum on collaboration and inclusion to prepare them to work together in school.

Yet, special education teachers need ongoing training due to the gap between their disability-specific teacher preparation and the demands of general education settings (Zaino, 1999). In addition, special education teachers often feel isolated and alienated by the dominant general education group and by the administration (Wasburn-Moses, 2009), and the feeling of isolation and alienation is one factor leading to attrition and job dissatisfaction for special education professionals (Billingsley, 2004). More research is needed on preparing special education teachers for their unique role in collaboration and inclusion in teacher education, as outlined in standards for special education.

Reflective practice and special education collaboration. As leaders and agents

of change, special education teachers have an opportunity to inspire general education teachers to work together toward the goal of inclusion and shared decision-making. New special education teachers need to see themselves not only as capable of influencing positive change, but morally responsible and committed to creating community that supports students with disabilities. As stated by Zeichner and Liston (1996), teachers need tools for making sense of and managing the culture and context of the school to be agents of change. Special education teachers could benefit from reflective practice as a 
tool to reflect on their experiences and think about ways to foster collaboration and inclusion.

Reflective practice means maintaining an ongoing habit of reflection by looking back on experiences and thinking about what is happening on a regular basis to learn and actively engage in decision making and change. Schön (1987) promotes reflective practice as a way for teachers to continually improve and grow professionally. In a study by Gallagher, Vail, and Monda-Amaya (2008), master's level general and special education teacher candidates were given a journaling assignment for reflection on collaboration in a collaboration course. An analysis of those journals revealed a range of perspectives on collaboration, and how candidates learned through reflection about their own communication and teaming skills, and the skills of others in relation to the course content. The findings showed candidates did not write about the limitations of collaboration such as time constraints and regular communication. That was attributed to learning about collaboration strategies in the related course. Most significant was the insight on candidates' perspectives and attitudes that journal reflections provided to candidates, and faculty was about to provide specific feedback and support based on those reflections. The integration of reflections is a practice that could allow teachers to 
do what is recommended by Zeichner and Liston (1996), to critically examine the inherent values in their practice as well as how their practice will lead to change.

Jay and Johnson (2000) developed a Teacher Education Program (TEP) typology

of reflection for the purpose of pedagogy in teacher education that specifies three categories of reflection: descriptive, comparative, and critical. Descriptive reflection is describing what happens in situation or circumstance around a perceived problem.

Comparative reflection involves seeking to understand others' points of view and perspectives, which may be incongruent with one's own, and making a comparison of different interpretations of the same matter. Critical reflection is the analysis of the situation and multiple perspectives, with an orientation to the broader context, different frames of reference, a moral imperative, and a decision to act. This typology represents a process of widening the lens of interpretation on experiences, which can lead to learning and change. Each category of the typology is not mutually exclusive, but intertwined. What is recommended is that teachers demonstrate an ability to engage in all three, with increasing ability to engage in critical reflection that can lead to agency (Jay \& Johnson, 2000). More research is needed to understand how reflective practice can support teachers as leaders and agents of change (LaBoskey, 2006). 
Summary of literature review. The literature review explored definitions and components of collaboration, standards related to collaboration for special education teachers, and research on the preparation of special education teachers for collaboration with general education teachers. Understanding what teacher candidates should know and be prepared to do to collaborate to include students with disabilities is critical for improving how teachers are prepared in teacher education. In addition, literature on reflective practice was reviewed as a tool for special education teachers to become agents of change, promoting and facilitating collaboration in schools.

A collaborative culture is one that recognizes how sharing knowledge and skills can result in a plan that is more effective than what one individual could accomplish independently. Friend (2000) asserts that diversity in classrooms has made collaboration a necessity, and it is unrealistic to expect one person to have enough expertise to meet the needs of all learners. Discussed in the literature review are critical components of collaboration to include personal commitment, communication skills, interaction skills, problem solving, and understanding the school context (Friend \& Cook, 2007).

Research recommends restructuring teacher education programs to prepare all teachers for collaboration, as well as gaining a better understanding of how special 
education teacher candidates in particular need to be prepared for their unique role in fostering and sustaining collaboration for inclusion. An overwhelming consensus in the

limited literature on this topic suggests that teacher education programs integrate content and field-based experiences so that special education teachers can develop the knowledge, skills, and dispositions for collaboration and inclusion prior to entering schools. 
Chapter 3

\section{Research Methods}

Collaboration between general and special education teachers is critical for the success of students with disabilities. The literature review identify components of collaboration, the role of special education teachers in fostering collaboration with general education teachers, and research on the preparation of special education teachers for collaboration in teacher education programs. The pilot study in this paper suggests that novice special education teachers begin with altruistic intentions to collaborate, but easily succumb to the status quo in schools of separate and autonomous teaching for those with and those without disabilities. Research is needed to determine if special education teachers will be more likely to maintain collaboration with general education teachers if prepared with coursework and student teaching field placements related to collaboration. Focusing on collaboration in higher education is believed to have a significant impact on the effectiveness of collaboration in schools (Coombs-Richardson \& Mead, 2001). However, research shows that collaboration is often not sufficiently addressed in teacher education programs (Shippen, et al, 2005). 
The purpose of this research was to understand the ways in which special

education teacher candidates experience collaboration with general education teachers to plan and coordinate instruction for students with disabilities, and to understand their perspectives of collaboration based on those experiences. What is emerging in the field of special education, and should be reflected in preparation for special education teachers, are new roles related to collaborating with general education teachers. The new roles are conducive to promoting inclusion and ensuring that students in special education have access to general education curriculum.

\section{Research Design}

The research method that best supported an investigation into the collaboration experiences and practices of special education teacher candidates was qualitative research. Qualitative research is described by Berg and Lune (2012) as a technique for examining, "[how] people learn about and make sense of themselves and others" (p. 8).

In contrast to quantitative research methods, which focus on proving or disproving a hypothesis, or trying to explain or predict a phenomenon, qualitative research allows patterns and multiple interpretations to emerge to explain or describe a phenomenon. The 
phenomenon being explored is related to the experiences of special education teacher candidates in their field placements.

Qualitative methods are important for understanding phenomenon about which little is known, and to gain more in-depth information that may be difficult to collect quantitatively (Berg \& Lune, 2012). This approach allows the researcher to understand the meaning of events in particular situations and gain entry into the conceptual world of the subjects (Bogdan \& Biklen, 1998). Gaining a deeper understanding of the collaboration experiences of special education teacher candidates involves looking at complex and interrelated factors in the school context, which are both internal and external to the subjects, and are not known. The research objective has a quantitative aspect as well, in that certain types of collaborative experiences will emerge, which can be quantified in an objective way. However, the goal of the research is not to quantify experiences, but to gather information about the subjective understandings of special education teacher candidates in relation to their experiences in schools observing and learning about collaboration with general education teachers.

A qualitative multiple-case study design and content analysis was used for exploring the experiences of special education teacher candidates. Case studies can be 
used to explore, describe, or explain a phenomenon (Yin, 2003). This research used an exploratory multiple-case study design that focused on the replication of a procedure with multiple subjects, from different contexts, to test or modify the theory that special education teacher candidates are learning about collaboration with general education from experiences in their field placement. Yin (2003) gives a technical definition of a case study as, "an empirical inquiry that investigates a contemporary phenomenon within its real-life context, especially when the boundaries between phenomenon and context are not clearly evident" (p. 13). The research questions the case study sought to explain are the why or how of a phenomenon (Yin, 2003). It allowed the exploration of multiple variables through multiple sources to understand contextual conditions. This design is preferred over single-case design because results can be generalized to theory and can inform theory development. Replication across cases is a critical component of multiplecase study design for either predicting similar results across cases, or contrasting results for predictable reasons.

A multiple-case study was most appropriate for addressing the research questions because there will be a single procedure repeated across multiple contexts and with multiple people, but with similar circumstances. The study of special education candidate 
collaboration during field experiences involved the study of subunits as depicted in

Figure 3. The context was collaboration experiences across three different special education teacher candidate student teaching experiences, and the cases were three different school levels (elementary, middle school, and high school). Cases include subunits of the special education teacher candidates (U1) and their special education mentor teachers (U2) in each context. Included in U1 and U2 was the use of documents related to the field experiences. Yin (2003) describes how case studies can be guided by a holistic or embedded design. A holistic design is open-ended in relation to a phenomenon as a single unit of analysis, and strives towards a holistic understanding of cultural systems of action. Embedded design studies the complexity of a phenomenon using multiple levels or units of analysis. It is instrumental in understanding a phenomenon at a subunit level. I used embedded design for this multiple-case study because there are multiple units of analysis for data collection.
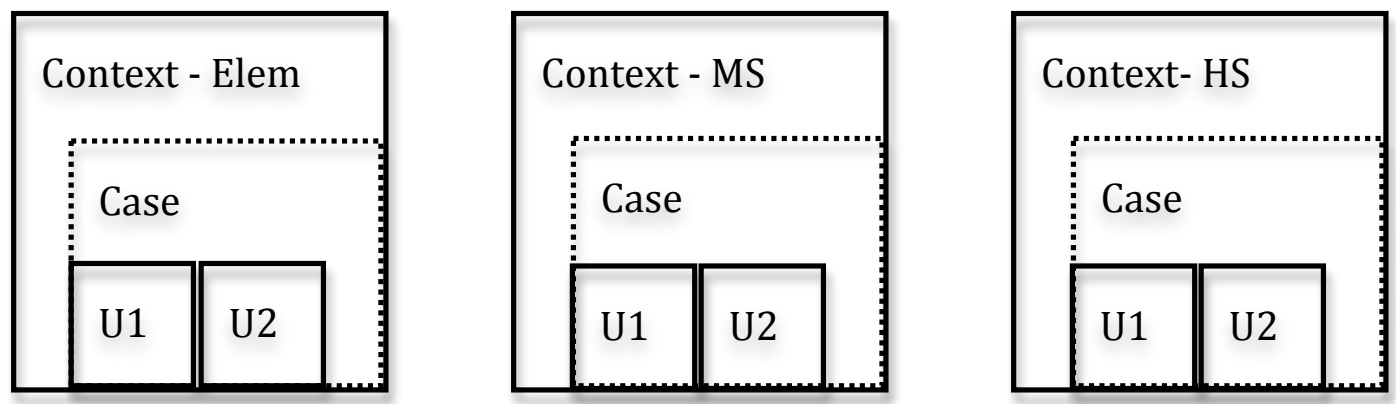

Figure 3. Embedded multiple-case design for collaboration in schools. 
Content analysis is a research methodology used "to uncover patterns of human activity, action, and meaning" from various forms of communication (Berg \& Lune, 2012, p. 351). It involves the collection, organization and interpretation of text data to include verbal language, print, survey questions, interviews, focus groups, observations, documents, audio and video tapes. Content analysis has historically been considered a quantitative research methodology because it involves counting retrieved text data and conducting statistical analysis. However, a qualitative approach to content analysis provides interpretations of latent content and context not evident in statistical data (Berg \& Lune, 2012). Qualitative content analysis extends beyond counting words to the interpretation of meaning embedded in communication.

Restatement of research questions. Research on the collaboration experiences of special education teacher candidates during field placements is lacking, and more information is needed on this topic to inform teacher education program revisions. The literature review revealed a lack of research on special education teacher candidate field experiences collaborating with general education teachers. There is a need to obtain a deeper understanding of the beliefs, perspectives, and experiences of special education teacher candidates in relation to collaboration. The research questions are as follows: 
1. To what extent are special education teacher candidates expected to collaborate with general education teachers during student teaching?

2. How are perspectives on collaboration with general education teachers different between special education teacher candidates and their mentor teachers?

\section{Participants}

The study included three special education teacher candidates and their mentor teachers. The special education teacher candidates were all members of a cohort of eight special education teacher candidates in an eighteen-month teacher education program. They were selected because they were simultaneously completing a full twelve-week student teaching requirement in three different grade level settings (elementary, middle school, and high school) at the time of the study, and their special education mentors agreed to volunteer as well. The special education teacher candidates and special education mentors were not selected for race, gender, experience, or type of special education classroom, but rather the grade level at which they were doing their student teaching, and their relationship to the university and researcher.

Special education teacher candidates. Table 2 describes the special education teacher candidate background information. Among the three special education teacher 
candidate participants, two were male, one was female, and they all range in age from 30

to 45 years. All three special education teacher candidates had a minimum four years

experience as instructional assistants in special education classrooms prior to special

education teaching. The special education teacher candidates took a leave from their

teaching assistant positions to complete the full time, twelve-week student teaching

requirement. Student teaching placements differed in school level and type of classroom

from teaching assistant experiences. All special education teacher candidates completed a

course on collaboration at the start of their student teaching, Spring 2012. The one-credit

course on collaboration consisted of three in-person classes for three hours each, and

three online modules. The course included information on collaboration styles, conflict

management, collaborative teaming, and co-teaching. However, course content and

assignments were not integrated or embedded in student teaching experiences.

Table 2

Special Education Teacher Candidate Information

\begin{tabular}{|l|c|c|c|c|c|c|}
\hline & Gender & Age & Race & $\begin{array}{c}\text { Years as } \\
\text { sped } \\
\text { assistant }\end{array}$ & Prior experience & $\begin{array}{c}\text { Placement } \\
\text { during study }\end{array}$ \\
\hline $\begin{array}{l}\text { Elementary } \\
\text { candidate }\end{array}$ & Male & 30 & White & 4 & $\begin{array}{c}\text { HS life skills } \\
\text { Teaching assistant }\end{array}$ & $\begin{array}{c}\text { Elementary } \\
\text { behavior } \\
\text { classroom }\end{array}$ \\
\hline $\begin{array}{l}\text { Middle school } \\
\text { candidate }\end{array}$ & Female & 45 & White & 5 & $\begin{array}{c}\text { Elem resource rm } \\
\text { Teaching assistant }\end{array}$ & $\begin{array}{c}\text { Middle school } \\
\text { life skills } \\
\text { classroom }\end{array}$ \\
\hline $\begin{array}{l}\text { High school } \\
\text { candidate }\end{array}$ & Male & 32 & White & 4 & $\begin{array}{c}\text { Elem resource rm } \\
\text { Teaching assistant }\end{array}$ & $\begin{array}{c}\text { High school } \\
\text { resource room }\end{array}$ \\
\hline
\end{tabular}

52 
Special education mentor teachers. Each special education mentor teacher

mentored one of the special education candidates during the twelve-week student

teaching, and volunteered to participate in the study. The special education mentor

teachers were selected by school administers because they were considered master

special education teachers with a minimum of two years as a special education lead

teacher in their own classrooms. Table 3 describes the special education teacher mentors

and their experiences.

Table 3

Special Education Mentor Teacher Information

\begin{tabular}{|l|c|c|c|c|l|l|}
\hline & Gender & Age & Race & $\begin{array}{c}\text { Yrs as } \\
\text { special } \\
\text { education } \\
\text { teacher }\end{array}$ & \multicolumn{1}{|c|}{ Certification } & $\begin{array}{l}\text { Type of special } \\
\text { education } \\
\text { classroom }\end{array}$ \\
\hline $\begin{array}{l}\text { Elem. } \\
\text { Special Ed. } \\
\text { Mentor }\end{array}$ & Male & 33 & White & 5 & $\begin{array}{l}\text { MS. Sped } \\
\text { Sped teaching license } \\
\text { K-8 }\end{array}$ & $\begin{array}{l}\text { Elementary } \\
\text { behavior } \\
\text { classroom }\end{array}$ \\
\hline $\begin{array}{l}\text { MS Special } \\
\text { Ed Mentor }\end{array}$ & Female & 49 & White & 8 & $\begin{array}{l}\text { MS. Sped } \\
\text { Elementary general ed } \\
\text { teaching license K-5 } \\
\text { Special ed teaching } \\
\text { license K-12 }\end{array}$ & $\begin{array}{l}\text { Middle school } \\
\text { life skills } \\
\text { classroom }\end{array}$ \\
\hline $\begin{array}{l}\text { HS Special } \\
\text { Ed Mentor }\end{array}$ & Male & 35 & White & 9 & $\begin{array}{l}\text { Masters in } \\
\text { Special education } \\
\text { Secondary sped } \\
\text { teaching license grades } \\
5-12\end{array}$ & $\begin{array}{l}\text { High school } \\
\text { resource room }\end{array}$ \\
\hline
\end{tabular}

Two of the special education teacher mentors were male and one was female. All

mentors were Caucasian. They ranged in age from 30 to 45 years. The elementary mentor 
teacher was in the Peace Corps for three years as a teacher of adults and children. That experience, according to his report, prepared him to be an effective communicator and collaborator. Following that experience, he received his special education teaching license from a public university in Oregon. He taught two years in Hawaii, and three years in the elementary research study setting. The middle school mentor teacher had an Oregon initial teaching license and endorsement in general elementary education, with two years teaching experience. She added a special education endorsement at the private university where this research was being conducted, and had been teaching in the lifeskills special education research study classroom for seven years. The high school mentor teacher had an undergraduate background in law and political science. He considered becoming a lawyer for Native American rights, but changed career plans after working as an instructional assistant in a special education classroom. He graduated from the private university where this research is being conducted, and had been teaching in the high school research study setting eight years.

Role of the researcher. My position as a researcher was as co-participant, meaning that I was engaged with participants in the discovery of knowledge. I conducted interviews and distributed a survey online with six participants. I explained that 
participation in the study was voluntary and provided choice and flexibility in how participation was possible. I met with special education mentor teachers in private locations or their classrooms, and used phone calls when follow-up meetings were needed. Analysis of documents and surveys were completed at the university. My relationship with the special education teacher candidates was as program coordinator, instructor, and student teaching supervisor. I was an instructor and student teacher supervisor for each special education teacher candidates prior to the research study. My relationship with the special education mentor teachers was as co-evaluator of the special education teacher candidates during student teaching. I shared university expectations with the special education mentor teacher and teacher candidates, and made weekly visits to the classroom over a twelve-week period.

\section{Settings}

University setting. The university setting was a college of education in a private university in the Pacific Northwest. The college prepared both general and special education candidates along separate licensure tracks in two counties. The special education teacher candidates in this study were three members of a cohort of seven special education license and Master's degree candidates at one of the campuses. The 
special education program is 18 months, starting in January and ending after a second spring. During the school year, candidates attend classes together at the university in the evenings, and are in public schools during the day. The study was conducted in the summer following the twelve-week student teaching placement during the second spring term. Student teachers did their student teaching in either an elementary school, middle school, or high school setting. The research did not take place in these settings, but with participants who taught or did student teaching in these settings. Access to these settings was not necessary, but a description of the settings is relevant for describing the context in which each participant was teaching or student teaching.

Elementary setting. The case study elementary setting was in an elementary special education classroom at a school located in central Oregon. The school was one of 16 elementary schools, was a Title 1 school, and had approximately 330 students in a district that had approximately 10,812 students (IES, 2013). Approximately $16.9 \%$ of students in the district received special education services. This elementary school had two special education classrooms, and two certified special education teachers. The school principal and district administrators hired the special education teachers and 
assistants to teach an early childhood kindergarten through second grade classroom, and a grade 3-5 behavior classroom.

The elementary special education classroom in the study was considered behavior classroom from grades 3-5. This classroom was designed to support students who had behaviors that interfered with their learning or the learning of others when in the general education classroom. There was a lead special education teacher and two instructional assistants in the classroom, supporting approximately twenty-two students. The students in this classroom had learning disabilities considered to be mild-moderate, as well as behavior disorders. They received their education in the general education classrooms 60$80 \%$ of their day.

Middle school setting. The case study middle school setting where the middle school special education teacher candidate did her student teaching was a Title 1 school, had a population of approximately 412 students, and was located in central Oregon in a district that serves more than 17,379 students (IES, 2013). Approximately $16 \%$ of students in the district received special education services. The school was one of two in the district that served students in kindergarten through $8^{\text {th }}$ grade. The middle school special education classroom in the study was one of three in the school, but unlike the 
other two classrooms, was under the supervision of separate administration, managed by the local Education Service District (ESD).

The ESD is a non-profit agency that provides services to 17 districts across the state of Oregon. One of the services provided by the ESD in this region was education to young children and individuals with severe disabilities in collaboration with school districts. The classroom where the special education teacher candidate did her student teaching was a guest classroom in the school, provided to the ESD to serve students from across the district with moderate to severe disabilities. The special education mentor teacher instructional assistants were hired by ESD administrators, and were not part of the faculty of the school or included in professional development and school events.

High school setting. The case study high school setting was located in central Oregon and was not a Title 1 school. It had a student population of approximately 1,971 students in a district that served approximately 40,403 students (IES, 2013). The high school was one of eight high schools in the district, and students in special education made up approximately $16 \%$ of the district student population.

The case study high school was considered a resource room for students with mild cognitive disabilities who were one or more grade levels behind in basic skills. It was one 
of two special education classrooms in the school, and served approximately twenty-five students with mild-moderate disabilities. There was one lead teacher and one assistant who provided between individual and small group instruction in reading and math in the special education classroom to support academics in general education classrooms. The students served in this classroom spent $80 \%$ or more of their school day in general education classrooms. The goal for many of the students was to participate in state testing and graduate with a regular diploma. The special education teachers and assistants were hired, and supervised, by both the school principal and a special education district administrator.

\section{Data Collection and Analysis}

Data instruments. Multiple instruments were used for this study, as recommended to increase construct validity and reliability (Yin, 1994). The instruments used in this study for data analysis included interview questionnaires designed for an open-ended question format, a survey/checklist of collaborative practices, and a rubric on typology of reflection.

An interview questionnaire was developed for gathering information related to collaboration using open-ended questions (Appendix A). The protocol included nine 
questions for special education teacher candidates, and ten questions for special education teacher mentors. The questionnaires were identical except for changes in wording to address the different roles of candidate and mentors. Two of the questions were designed to gather personal background and classroom information. The special education mentor teacher interview included one additional question than the special education teacher candidate interview, related to preparation of teacher candidate preparation for collaboration.

A Collaborative Practices Survey Instrument and Checklist (Appendix B) was developed as both a survey to be used with participants, and as a checklist for data analysis. It includes eleven collaborative roles of special education teachers, as described by Friend and Cook (2007), specific to collaboration with general education teachers. The survey/checklist included eleven categories, which were cross-referenced with CEC standards for special education teacher preparation. Six of the eleven categories in the instrument were aligned with CEC standards for special education teacher preparation. The instrument was used as a survey and the predetermined categories were used as a checklist for document and interview analysis. 
A Typology of Reflection Rubric (Appendix C) was developed based on the work of Jay and Johnson (2002). It was used for analyses across all data sources for evidence of reflection. The typology includes three types of reflections to include: descriptive, comparative, and critical. The descriptive reflection is related to tasks, systems, and actions of self and others. It is the type of reflection where problems and situations are described. A comparative reflection extends beyond descriptive reflections as evidenced by an attempt to make sense of a problem or situation and avoid assumptions. In comparative reflection, the teacher may look at the situation or problem from other perspectives and attempt to reframe the surface description. Critical reflection reaches an even deeper or more robust examination of a situation or problem by integrating perspectives of self and others and making a judgment, taking into consideration best practices, values, and broader socio-political and moral implications.

Documents. The Collaborative Practices Survey and Checklist, and Typology of Reflection Rubric instruments were used in the analysis of Student Teaching Work Samples, and Student Teaching Summary Evaluations.

The Teaching Work Sample (TWS) is a performance-based assessment originally developed at Western Oregon University (Shalock, 1998; Shalock, Cowart, \& Staebler, 
1993). It is type of portfolio completed by teacher candidates during student teaching in schools to document planning, teaching, and assessment of an instructional unit as part of licensing requirements. The Teaching Work Sample is also used by teacher education programs to show evidence that teacher candidates meet state and national teaching standards (McComney, Shalock, \& Schalock, 1998). The components of the teaching work sample are aligned with INTASC standards, and include evidence that candidates have the knowledge, skills, and dispositions to collaborate, create a supportive learning environment, teach a diverse community of learners, and engage in reflective practice. The work sample includes a description of the setting, service documents such as IEPs and behaviors plans, descriptions of the needs, interests, and strengths of targeted students for teaching, a rationale for the topic selected, ten lesson plans, ten lesson reflections, assessments, a teaching reflection, and a list of resources and contacts. The complete document ranges between 50 and 100 pages of narratives, graphs, and lesson frameworks. Special education teacher candidates in each setting completed a work sample with a group of students.

The Student Teaching Summary Evaluation is used to evaluate student teaching in six categories, aligned with initial teaching license competencies outlined by the Oregon 
Teachers Standards and Practices Commission (TSPC). Categories of the evaluation include: planning for instruction, establishing a classroom climate, standards-based teaching, assessment, content knowledge, and professional behavior. Across the six categories are six items related to general education and/or collaboration. The following are the specific items related to collaboration:

- Standard 2: Establishing Classroom Climate

c. Employ equitable practices that are just and that support a least restrictive environment for all students.

- Standard 4: Assessment

b. Document student progress in accomplishing State-adopted content standards and district standards, prepare data summaries that show this progress to others, and inform students, supervisors, and parents about progress in learning.

- Standard 6: Professional Behavior

f. Interact constructively and respectfully with students, colleagues, administrators, supervisors, school staff, families, and members of the community.

g. Collaborate with parents, colleagues, and members of the community to provide internal and external assistance to students and their families to promote student learning.

h. Perform advisory functions for students in formal and informal settings.

i. Function as a member of an interdisciplinary team to achieve long-term curriculum goals, and State content standards and district standards.

The special education mentor and university supervisor completes the Student

Teacher Evaluations in the middle and at the end of the twelve-week student teaching

placement. Special education teacher candidates are rated 0-6 on items in each standard. 
The rating scale ranges from not demonstrating $(0)$, to developing awareness (1-2) to knows and demonstrates skill (3-4), to demonstrates well (5-6). Candidates need to get a composite score of three in each category to pass student teaching.

Data collection procedures. Data collection for this research involved six planned interviews and surveys with each participant, and analysis of student teaching documents. The data collection process began after special education teacher candidates graduated from the teacher education program and was completed over summer and fall, 2012. Interviews were the first step in the data collection process, and began upon approval from Human Subject Review Board in early summer, 2012. Participants were invited by email to participate in face-to-face interviews at a time and location that was convenient for them. All interviews were digitally recorded and transcribed using a word processer and pen and paper. Interview questions were structured to stay focused on the research during the interview. The interviews lasted an average of 30 minutes each. The interview questions were designed to gather general information about the context, role of the special education teacher, perspectives of successful collaboration, perspectives of challenges with collaboration, perceived experiences of the special education teacher candidates in relation to collaboration, and recommendations for teacher preparation for 
collaboration. Follow- up interviews were conducted with the middle school mentor teacher, and the middle school special education teacher candidate in fall, 2012 for clarification and to gather additional information.

Surveys were sent to participants electronically in fall, 2012, following the interviews. Participants responded to eleven questions related to collaborative practices outlined by Friend and Cook (2007), and had the option of providing open-ended comments. All participants completed the survey. The Teaching Work Sample and Student Teacher Evaluation text documents were accessible through the university teacher education program. A literal replication of each case study involved repeating the same data collection process for each case study in response to each research question.

Data analysis. The first step in the data analysis process involved retrieving, counting, organizing, and indexing data into categories. A paper trail was created with the interview transcriptions, surveys, and document analysis to determine what was being observed, said, and documented. This was done to establish a chain of evidence (Yin, 2003) to verify findings. A constant comparative method of data analysis (Merriam, 1998) was used as a means of constantly comparing data obtained from interviews, surveys, and documents to find patterns and themes within and across units. Pre- 
determined categories of collaborative practice (Appendix B) were used to code the interviews, work samples, and student teaching evaluations, and were the basis of the survey questions. Additional categories and subcategories were also derived from themes that emerged from interviews and field-based documents. Notes and memos were used during analysis to record patterns and impressions, and collect information related to expectations and perspectives. This analysis process was replicated for each of the three school contexts, and a case study database was created for categories, note taking, transcriptions, and researcher narratives.

The interviews were the first data source to be coded and analyzed. The interview questions were open-ended to get perspectives about the purpose, challenges, and success of collaboration without using guided prompts about specific components of collaboration, to see what themes emerged. An analysis of interviews was done using both a deductive and inductive coding scheme. An inductive approach was used to code for collaborative practices, perspectives on collaboration, and typology of reflection. A deductive analysis was based on the pre-determined categories of collaborative practices (Appendix B). An inductive approach uses the data to generate themes, and a deductive approach starts with an idea or theoretical framework and uses the data to verify or 
disprove ideas (Holloway, 1997). The analysis started with inductive coding, to identify patterns in the data and establish categories. The theoretical constructs were reviewed to help explain and evaluate the categories.

Coding of interviews began with an inductive analysis in response to research question one. Generative themes were matched to the categories and new categories were created. I started with counting and comparing key words, phrases, and content related to collaboration with general education teachers, with the intent to understand both the extent of experiences as relevant to research question one, and to capture data from narratives that revealed new categories on collaborative practices, and typology of reflection. This approach went beyond the manifest content, extending to an interpretation of underlying latent meanings and themes (Berg \& Lune, 2012), particularly when analyzing for a typology of reflection.

A deductive analysis of interviews followed with the coding of pre-determined categories to look for evidence of expectations. Categorization codes were established for the data during analysis as "C\#" (corresponding to collaborative categories 1-11), "P" for perspective, and "R" for reflection. An analysis of the data for research question one involved looking at a combination of patterns across unit settings, with special education 
mentors, and special education teacher candidates. To enhance the validity of the results, I looked for ways to triangulate the data. Triangulation is recommended as a way to reduce bias and gain a broader understanding of phenomena, and involves combining different data collection methods or varied sources (Maxwell, 2005). For question one, I was able to triangulate data sources to include: interviews, surveys, teacher work samples, and student teaching summary evaluations. I followed up 3 months after the interviews with an electronic survey of collaborative practices. Surveys were coded directly from these categories as yes or no, to indicate happening or not happening to determine the extent that special education teacher candidates were expected to collaborate. Generative themes emerged and were collected and analyzed based on frequency. The text was coded a third time for evidence of typology of reflection; " $\mathrm{D}$ " for descriptive, "Com" for comparative, and "CR for critical. A search selected first for critical reflection, then comparative, then descriptive. Examples were highlighted from each participant. An analysis for perspectives was not applied to text documents.

Data was analyzed continually, throughout the study, from conceptualization through the entire data collection phase, into the interpretation and writing phases. The process of data analysis was replicated across the three settings of embedded units. A 
data table was created to compile the responses from the interviews, surveys, and text documents. The first phase of analysis involved transcription of the interview data and written notes, comprehensive written summaries of each interview, and review of transcripts and summaries with participants. Based on discussions during data analysis review, I found that additional questions were warranted from the middle school special education mentor and middle school special education teacher candidate. A second phase of analysis took place following the second interview to compare and contrast the middle school mentor and teacher interviews, and distribute surveys. The third phase of analysis involved looking for categorical data in work samples and student teaching evaluation documents from field placements, and revisiting the literature review to support or contradict the propositions.

Trustworthiness. Credibility was gained through triangulation of data sources, peer debriefing, and follow-up interviews with select participants. Transcripts, coding, and interpretations of text were reviewed by a doctoral-level colleague familiar with qualitative research in the area of education. An analysis of evidence of the extent that special education teacher candidates collaborated was done through a triangulation of data sources. This was done to reduce the risk of bias from any one source, and to gain a 
broader scope of evidence. It was gathered and analyzed in the same way in all three contexts. A comparison of the results of each instrument was done to look for internal validity between instruments.

A limitation of embedded design is the risk of neglecting to put the subunits into a larger context for analysis. To address this, I provided thorough descriptions of the setting using data collected from special education mentor teachers, special education teacher candidates, and student teacher work samples. A limitation of directive content analysis approach is the researcher may approach the collection, analysis, and interpretation of data with a bias toward finding certain evidence, and overlooking seemingly unrelated contextual aspects of the phenomenon. This is my sixth year as a faculty member and the coordinator, cohort leader, university supervisor, and main instructor in the special education program. I prepare special education teacher candidates to complete the student teaching work samples, evaluate their teaching performance and teaching work samples, complete teaching observations, and make decisions about their qualifications and recommendation for a special education license. In addition, I taught the course on collaboration taken by special education teacher candidate participants prior to student teaching. As an instructor, I have been an advocate for collaboration in 
schools, inclusion, reflective practice, and teacher leadership. To address possible bias, an audit of definitions, codes, and interpretations of text was provided by a colleague with qualitative research experience (Berg \& Lune, 2012).

Ethical considerations. Risks for participants in this research were minimal. Although personal information about participants was gathered, it remained confidential so the names of participants would not be known. Confidentiality was protected by saving information in a file on a computer that was password protected and keeping any physical documents in a locked filing cabinet. Data will be destroyed following the completion of this study. Names of participants were not used and instead were identified by context and position to keep data confidential. Text analysis did not directly involve participants, settings were not identified by name, and participation was voluntary. Data was collected after completion of the program, at which time the researcher was no longer a university supervisor. Participants were informed that they could withdraw at any time or decline to answer any individual question that they were not comfortable with. An outcome of this research will be to gain a better understanding of the actual and ideal collaborative experiences of special education teacher candidates while in field placements. This information could inform teacher education programs of ways to 
prepare special education candidates to collaborate, and provide information for improved curriculum and instruction on collaboration at the pre-service level. 


\section{Chapter 4}

\section{Results}

The research questions guiding the present study are: (a) To what extent are special education teacher candidates expected to collaborate with general education teachers during student teaching, and (b) How are perspectives of collaboration different between special education teacher candidates and their mentor teachers. As described in the previous chapter, a multiple-case study method and multiple data sources were used to address the research questions in three school contexts (Table 4). Data were coded and analyzed from surveys and interviews with individual special education mentor teachers and their special education teacher candidates from each of the three contexts. In addition, text analysis was done on student teaching documents required by the university as performance measures for licensure. In this chapter, the results of the data analysis from all sources in each school context are described. A summary of the results is at the end of the chapter, followed by a discussion. 
Table 4

School Contexts and Data Sources

\begin{tabular}{|c|c|c|}
\hline $\begin{array}{l}\text { Elementary Special } \\
\text { Education }\end{array}$ & $\begin{array}{l}\text { Middle School Special } \\
\text { Education }\end{array}$ & $\begin{array}{l}\text { High School Special } \\
\text { Education }\end{array}$ \\
\hline $\begin{array}{l}\text { Special Education Mentor } \\
\text { Teacher } \\
\text { - } \quad \text { Survey } \\
\text { - } \quad \text { Interview }\end{array}$ & $\begin{array}{l}\text { Special Education Mentor } \\
\text { Teacher } \\
\text { - } \quad \text { Survey } \\
\text { - } \quad \text { Interview }\end{array}$ & $\begin{array}{l}\text { Special Education Mentor } \\
\text { Teacher } \\
\text { - } \quad \text { Survey } \\
\text { - } \quad \text { Interview }\end{array}$ \\
\hline $\begin{array}{l}\text { Special Education Teacher } \\
\text { Candidate } \\
\text { - } \quad \text { Survey } \\
\text { - Interview }\end{array}$ & $\begin{array}{l}\text { Special Education Teacher } \\
\text { Candidate } \\
\text { - Survey } \\
\text { - } \quad \text { Interview }\end{array}$ & $\begin{array}{l}\text { Special Education Teacher } \\
\text { Candidate } \\
\text { - Survey } \\
\text { - } \quad \text { Interview }\end{array}$ \\
\hline $\begin{array}{ll}\text { Student Teaching Documents } \\
\text { - } & \text { Student Teaching Work } \\
\text { - Sample } \\
\text { - Student Teaching } \\
\quad \text { Evaluation } \\
\end{array}$ & \begin{tabular}{ll}
\multicolumn{2}{l}{ Student Teaching Documents } \\
- $\quad$ Student Teaching Work \\
Sample \\
- $\quad$ Student Teaching \\
Evaluation \\
\end{tabular} & $\begin{array}{ll}\text { Student Teaching Documents } \\
\text { - } \quad \text { Student Teaching Work } \\
\text { Sample } \\
\text { - } \quad \text { Student Teaching } \\
\text { Evaluation } \\
\end{array}$ \\
\hline
\end{tabular}

\section{Elementary Special Education Case Study}

The elementary special education classroom was considered a behavior

classroom, which meant a majority of the students had behaviors that interfered with their

learning or the learning of others when in the general education classroom. The

elementary special education mentor teacher described the class as providing a full

continuum for everything but life skills. The primary function of the classroom was

behavior, but the special education mentor felt it was also a successful mainstream

program. 
The students in the elementary classroom were in grades 3 through 5 with mild to moderate special education needs. The primary disabilities of the students included Autism Spectrum Disorder, Learning Disabilities, and Emotional Disorder. Some students in the class had no IEP but had been defiant in the general education classroom. When the students were not in the behavior classroom, they were in the general education classrooms with intermittent support from assistants and the lead teacher. The students attended general education classrooms $60-80 \%$ of their day, depending on their success in the general education classroom. Four students remained in the behavior classroom full days. In the behavior classroom, students received small group instruction in reading and math five to ten hours per week. In addition to individualized instruction in reading and math, all students who attended the behavior class were learning social skills and selfregulation strategies appropriate for the general education classroom. The classroom had one full time special education teacher and two full time teaching assistants for 17-22 students.

The elementary special education teacher candidate shared that prior to this 12 week student teaching experience, he had not worked in an elementary classroom before, and had not worked with students with behavior challenges. Most of his experience was 
teaching small groups in the special education classroom, but he did implement behavior

plans established by the special education teacher mentor when on the playground.

Survey results of elementary participants. The survey results provided data in

response to research question one, on the extent that the elementary special education

teacher candidate was expected to collaborate with general education teachers. Codes

were based on predetermined categories and represented as + (yes) or - (no) to indicate if

the collaborative practices were expected of the elementary special education teacher

candidate (Table 5).

Table 5

Survey Results on Elementary Collaborative Practice

\begin{tabular}{|l|c|c|}
\hline Collaborative Practices & \multicolumn{2}{|c|}{ Elementary School } \\
\hline & $\begin{array}{c}\text { Special Ed } \\
\text { Mentor } \\
\text { Teacher }\end{array}$ & $\begin{array}{c}\text { Special Ed } \\
\text { Teacher } \\
\text { Candidate }\end{array}$ \\
\hline $\begin{array}{l}\text { 1) Include the general education teacher as equal partner in } \\
\text { planning, delivery and assessment of student learning }\end{array}$ & - & - \\
\hline 2) Identify / communicate adaptations & + & + \\
\hline 3) Ensure copies of IEPs to address goals in general ed classroom & + & - \\
\hline 4) Involve gen ed in IEP development / implementation & + & + \\
\hline 5) Include instructional Asst. in collaborative plans & + & + \\
\hline 6) Observations in general education classrooms & + & + \\
\hline 7) Coordination of assessments with gen ed input and feedback & + & - \\
\hline 8) Coordination of meetings and progress monitoring with gen ed & + & + \\
\hline $\begin{array}{l}\text { 9) Utilize knowledge of disabilities /instruction to facilitate gen ed } \\
\text { access }\end{array}$ & + & + \\
\hline 10) Co-teach & - & - \\
\hline 11) Collaborative problem solving & - & - \\
\hline
\end{tabular}


In the elementary case study, the special education teacher candidate reported fewer expectations for collaboration than his mentor teacher. Both elementary participants identified six of the eleven collaborative practices as an expectation during student teaching to include: identifying and communicating adaptations, involving general education teachers in the development and implementation of the IEP, including instructional assistants in collaborative practices, observing in general education classrooms, coordination of meetings and progress monitoring, and utilizing knowledge of disabilities to facilitate access to general education curriculum and classrooms. The elementary participants were also in agreement there was no expectation of including general education teachers as an equal partner in planning, delivery and assessment of student learning, co-teaching, and collaborative problem solving. They differed in that the elementary special education mentor teacher had an expectation the special education teacher candidate share IEPs with general education teachers and coordinate assessments, but this was not an expectation of the teacher candidate.

Interviews with elementary participants. The interview results were analyzed in response to research questions one and two. To determine the extent the elementary special education teacher candidate was expected to collaborate with general education 
teachers, text was coded from interviews using a deductive and inductive analysis. Codes

were applied to interpretations of text based on the pre-determined categories and open

coding allowed themes to emerge. Table 6 shows data results as coded + (yes) or - (no)

to indicate if there was a match between participant responses to open-ended interview

questions and the collaborative practices identified by Cook and Friend (2007).

Table 6

Interview Results of Elementary Collaboration

\begin{tabular}{|c|c|c|}
\hline Collaborative Practices & $\begin{array}{c}\text { Elem Sped Mentor } \\
\text { Teacher }\end{array}$ & $\begin{array}{l}\text { Elem Sped Teacher } \\
\text { Candidate }\end{array}$ \\
\hline $\begin{array}{l}\text { 1) Include the general education } \\
\text { teacher as equal partner in planning, } \\
\text { delivery and assessment of student } \\
\text { learning }\end{array}$ & + & - \\
\hline $\begin{array}{l}\text { 2) Identify / communicate } \\
\text { adaptations }\end{array}$ & + & - \\
\hline $\begin{array}{l}\text { 3) Ensure copies of IEPs to address } \\
\text { goals in general ed classroom }\end{array}$ & - & - \\
\hline $\begin{array}{l}\text { 4) Involve gen ed in IEP } \\
\text { development / implementation }\end{array}$ & - & - \\
\hline $\begin{array}{l}\text { 5) Include instructional Asst. in } \\
\text { collaborative plans }\end{array}$ & - & - \\
\hline $\begin{array}{l}\text { 6) Observations in general education } \\
\text { classrooms }\end{array}$ & $\begin{array}{c}+ \\
\text { Need to provide a } \\
\text { continuum of support } \\
\text { from gen ed to self- } \\
\text { contained classrooms }\end{array}$ & $\begin{array}{l}+ \\
\text { Every day I followed the } \\
\text { mentor teacher to gen ed } \\
\text { classrooms }\end{array}$ \\
\hline $\begin{array}{l}\text { 7) Coordination of assessments with } \\
\text { gen ed input and feedback }\end{array}$ & - & - \\
\hline $\begin{array}{l}\text { 8) Coordination of meetings and } \\
\text { progress monitoring with gen ed }\end{array}$ & $\begin{array}{c}+ \\
\text { Need to learn through } \\
\text { observation how to } \\
\text { have a } 30 \text { second } \\
\text { meeting }\end{array}$ & $\begin{array}{l}+ \\
\text { I followed along as mentor } \\
\text { teacher did 'on the fly } \\
\text { meetings" with general } \\
\text { education teachers in a } \\
\text { variety of locations }\end{array}$ \\
\hline $\begin{array}{l}\text { 9) Utilize knowledge of disabilities } \\
\text { /instruction to facilitate gen ed access }\end{array}$ & - & - \\
\hline 10) Co-teach & - & - \\
\hline 11) Collaborative problem solving & - & - \\
\hline
\end{tabular}


Based on the interviews with the elementary participants, it was determined there

was consensus that elementary special education teacher candidates were expected to do

observations in general education classrooms, and coordinate meetings. These two

expectations were consistent with the survey results, but the survey identified many more

expectations not evident in the interview. Table 7 shows additional themes that emerged

from elementary participant transcribed interviews that were not included in the pre-

determined categories to include communication skills, building trust, and being

accountable.

Table 7

Emerging Themes from Elementary Interview

\begin{tabular}{|c|c|}
\hline $\begin{array}{l}\text { Elementary } \\
\text { special education } \\
\text { mentor teacher }\end{array}$ & 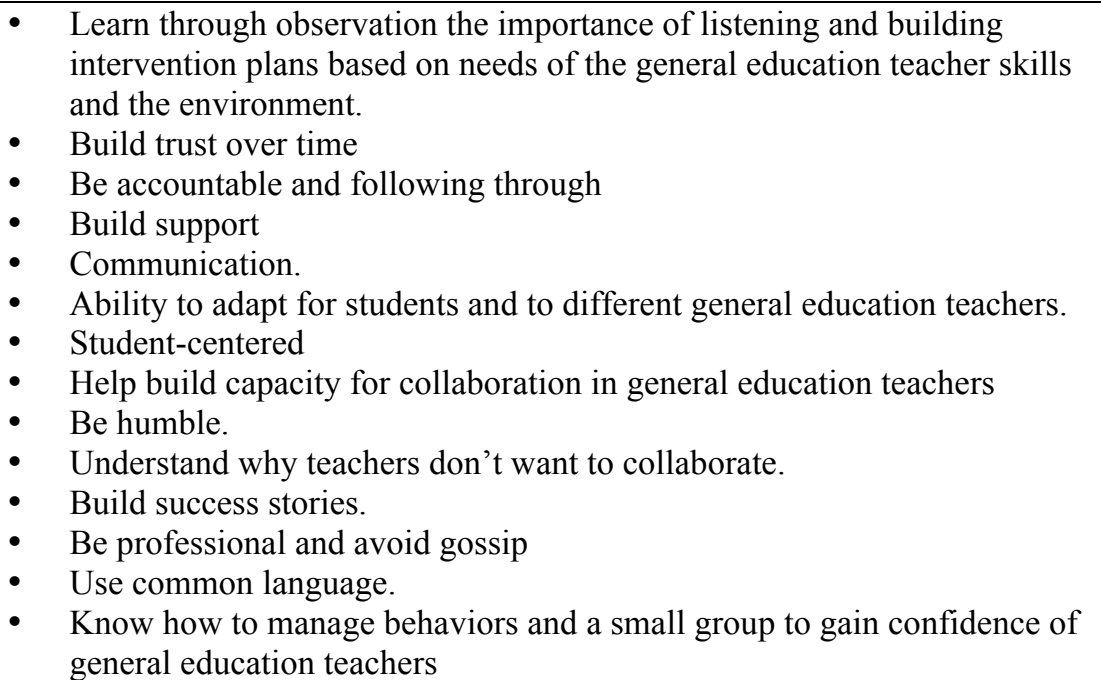 \\
\hline $\begin{array}{l}\text { Elementary } \\
\text { special education } \\
\text { teacher candidate }\end{array}$ & $\begin{array}{l}\text { - Work with small groups of special education students providing intensive } \\
\text { intervention in collaboration with general education teacher for one week } \\
\text { - } \quad \text { have a common vision about what's best for students } \\
\text { - teamwork, teambuilding, } \\
\text { - } \quad \text { be student-centered }\end{array}$ \\
\hline
\end{tabular}


Elementary participant perspectives. Table 8 shows a summary of elementary

special education mentor and special education teacher candidate perspectives on

collaboration in response to research question two. The elementary special education

mentor teacher had a much richer response for each question than the elementary special

education teacher candidate. Shared perspectives included team building, relationship

building, being student-centered (vs. centered on the needs of teachers), and establishing

clear roles. The elementary special education mentor teacher had additional perspectives

that are consistent with the research on positive attitudes for collaboration to include;

parity, building on success, role release, mutual goals, trust, learning to listen,

commitment to the process, regular communication, and effective with adaptations and

behavior management. There were no negative perspectives on collaboration noted

throughout both interviews, and no contradictions in responses.

Table 8

Elementary Participant Perspectives

\begin{tabular}{|l|l|l|c|}
\hline Interview questions & Special Education Mentor Teacher & $\begin{array}{l}\text { Special Education } \\
\text { Teacher } \\
\text { Candidate }\end{array}$ & Congruence \\
\hline $\begin{array}{l}\text { What's important about } \\
\text { collaborating with } \\
\text { general education } \\
\text { teachers? }\end{array}$ & $\begin{array}{l}\text { Building trust. Being accountable. } \\
\text { Building support }\end{array}$ & $\begin{array}{l}\text { Common vision } \\
\text { about what's best } \\
\text { for students (with } \\
\text { disabilities) }\end{array}$ & - \\
\hline $\begin{array}{l}\text { How does collaboration } \\
\text { with general education } \\
\text { teachers help students } \\
\text { with disabilities? }\end{array}$ & $\begin{array}{l}\text { Parity. (says it's needed) } \\
\text { Communication. (says it's needed) }\end{array}$ & $\begin{array}{l}\text { Improves } \\
\text { academics and } \\
\text { behavior }\end{array}$ & - \\
\hline
\end{tabular}


Table 8 (continued)

\begin{tabular}{|c|c|c|c|}
\hline Interview questions & Special Education Mentor Teacher & $\begin{array}{l}\text { Special Education } \\
\text { Teacher } \\
\text { Candidate }\end{array}$ & Congruence \\
\hline $\begin{array}{l}\text { What makes } \\
\text { collaboration with } \\
\text { general education } \\
\text { teachers successful? }\end{array}$ & $\begin{array}{l}\text { Little successes } \\
\text { Ability to adapt for students } \\
\text { Ability to read and respond to the } \\
\text { different needs and styles of general } \\
\text { education teachers } \\
\text { Keep it about the students } \\
\text { Collaborative goal development } \\
\text { Building a relationship over time } \\
\text { Trust }\end{array}$ & $\begin{array}{l}\text { Teamwork } \\
\text { Teambuilding } \\
\text { Being student } \\
\text { centered }\end{array}$ & $\begin{array}{l}+ \text { (student- } \\
\text { centered })\end{array}$ \\
\hline $\begin{array}{l}\text { What are the challenges } \\
\text { to collaboration with } \\
\text { general education } \\
\text { teachers }\end{array}$ & $\begin{array}{l}\text { Time: to build rapport and understand } \\
\text { strengths and weaknesses of general } \\
\text { education teachers; time to plan and } \\
\text { follow up. } \\
\text { Letting go. It (the goal) is not about me, } \\
\text { but about the student and building } \\
\text { capacity in general education teachers }\end{array}$ & Role confusion & - \\
\hline $\begin{array}{l}\text { What do you see as the } \\
\text { role of special education } \\
\text { teachers in fostering } \\
\text { collaboration with } \\
\text { general education } \\
\text { teachers? }\end{array}$ & $\begin{array}{l}\text { Set up a continuum of individualized } \\
\text { academic and behavior support systems } \\
\text { for students and teachers } \\
\text { Be available } \\
\text { A facilitator for students and teachers- } \\
\text { asking questions, getting input, creating } \\
\text { plans, following up } \\
\text { "It's a living breathing plan that changes } \\
\text { all the time" } \\
\text { Coordinate EA support to be available to } \\
\text { observe and problem solve } \\
\text { Eliminate ambiguity so students see } \\
\text { teachers being united } \\
\text { I am a facilitator, administrator, } \\
\text { coordinator of schedules and plans, } \\
\text { provider of behavior and academic } \\
\text { strategy and support }\end{array}$ & $\begin{array}{l}\text { Important to be } \\
\text { clear what role is }\end{array}$ & $\begin{array}{c}+ \text { (Clear } \\
\text { roles })\end{array}$ \\
\hline $\begin{array}{l}\text { What is important for } \\
\text { special education } \\
\text { candidates to learn about } \\
\text { collaboration during } \\
\text { student teaching? }\end{array}$ & $\begin{array}{l}\text { Be humble } \\
\text { Understand why teachers don't want to } \\
\text { collaborate. } \\
\text { Learn to listen } \\
\text { Build success stories } \\
\text { What it means to be professional } \\
\text { Use common language } \\
\text { How to collaborate with educational } \\
\text { assistants } \\
\text { Need to consider plan in context of } \\
\text { environment. } \\
\text { Need to know how to manage behaviors } \\
\text { and a small group to gain confidence of } \\
\text { general education teachers }\end{array}$ & $\begin{array}{l}\text { What more would } \\
\text { you like to have } \\
\text { learned about } \\
\text { collaboration? } \\
\text { Practice team } \\
\text { teaching }\end{array}$ & - \\
\hline
\end{tabular}


The elementary mentor teacher emphasized how collaborative relationships depend upon a commitment to establish trust and build authentic personal relationships among the team early in the process. Classroom size, teacher fatigue, and time were mentioned as barriers to collaboration. Also mentioned by the elementary mentor teacher was the importance of developing relationships with other teachers, and to develop trust. Noted are particular challenges fostering collaboration as a first year teacher while trying to stay on top of things. The purpose of collaboration for the elementary mentor teacher was related to problem solving behavior challenges rather than adapting and assessing curriculum and instruction. The elementary special education teacher candidate emphasized teambuilding and developing common goals for students as critical for collaboration with general education teachers. The elementary mentor teacher had significantly more comments to each interview question than the elementary special education teacher candidate.

Elementary typologies of reflection. Reflections from the elementary school case study interviews and text documents were analyzed for typology of reflection (Table 9). Text documents did not show evidence of reflection on collaboration. The elementary mentor teacher interview shows openness to other perspectives, a sense of 
responsibility to the process, and a commitment to continued personal and professional

growth. I categorized mentor teacher remarks as comparative rather than critical

because of the focus on problem solving rather than on deeper democratic purposes

of public education. The elementary teacher candidate reflections were categorized as

descriptive, focusing on the details of situations, but not comparing it to the experiences

of self or others, considering other perspectives, or showing understanding of the larger

context.

Table 9

Typology of Reflection Narratives: Elementary

\begin{tabular}{|c|c|c|}
\hline & Elementary Sped Mentor Teacher & $\begin{array}{l}\text { Elementary Sped } \\
\text { Teacher Candidate }\end{array}$ \\
\hline $\begin{array}{l}\text { How is } \\
\text { disposition } \\
\text { reflected in } \\
\text { language that } \\
\text { describes } \\
\text { collaboration? } \\
\text { (typology of } \\
\text { reflection) }\end{array}$ & $\begin{array}{l}\text { Comparative reflections- considering alternate views } \\
\text { and ways to improve situation. } \\
\text { If I start off saying here's where I see us going, or they } \\
\text { start off saying here's where I see us going, there is } \\
\text { already a huge difference between the two of us. But if } \\
\text { we start as here's where we are at, and we both agree } \\
\text { on where we are starting off then we are starting on our } \\
\text { similarities. And we go from there because there is a } \\
\text { good chance that how I think it should be is not how it } \\
\text { should be cause every situation is a little different. So, if } \\
\text { I go in with an idea that things should go a certain way } \\
\text { then I am setting myself up to be wrong. } \\
\text { There is a fatigue that comes along every two years, } \\
\text { there is a new best thing.. I don't see consultants doing } \\
\text { what they recommend. It's got to be hard to be a teacher } \\
\text { and say I don't know what to do about certain kids. I } \\
\text { have thirty kids in here and one student is disrupting the } \\
\text { class and no one is able to show me a better way. I also } \\
\text { realize that I have strengths and weaknesses too, and I } \\
\text { don't want to make a plan that I can't be able to help } \\
\text { out with. I want to understand my own strengths and } \\
\text { weaknesses too and play off them. }\end{array}$ & $\begin{array}{l}\text { Descriptive- tells what is } \\
\text { happening } \\
\text { When..... general } \\
\text { education teachers } \\
\text { needed help with some } \\
\text { student's behaviors they } \\
\text { did not know who to go } \\
\text { to. The teacher did not } \\
\text { think it was the special } \\
\text { education teacher's } \\
\text { fault. She thought it was } \\
\text { the administrators. She } \\
\text { argued that the } \\
\text { administrators did not } \\
\text { do enough to collaborate } \\
\text { and train the special } \\
\text { education teachers and } \\
\text { others about RTI. }\end{array}$ \\
\hline
\end{tabular}


Elementary document analysis. A content analysis was done the Student

Teaching Work Sample and the Student Teaching Evaluation elementary field-based

documents. The elementary work sample described the planning, teaching, and

assessment done with two fourth grade male students. The focus of the elementary work

sample was on reading comprehension strategies. One student had an eligibility of

Emotionally Disturbed, and the other student had multiple eligibilities in the areas of

Communication Disorder, Other Health Impairment, and Specific Learning Disability.

Both students were one grade level behind in reading and attended the resource room one hour per day for specialized instruction in reading. The remainder of their day was spent in a general education classroom. Both students were on a behavior point card system across school environments. The work sample consisted of 96 pages of description, templates, graphs, and reflections. There was no mention in the work sample of generalizing the targeted strategies to other environments such as the general education setting, no mention of collaboration with general education teachers in the planning, teaching or assessment of learning objectives, and no documented alignment to the curriculum and instruction in the general education classroom. 
The Student Teaching Summary Evaluation is a rating scale of teaching

effectiveness aligned with TSPC standards, completed by the elementary special education mentor teacher and the university supervisor in the middle and at the end of the 12-week student teaching experience to document meeting standards. The evaluation include broad measures of collaboration, but there was no clear evidence that showed an expectation the elementary special education teacher candidate teachers engaged in the collaborative practices identified in the research. There was a general expectation to share information, interact and advise with others, but it did not clearly match the collaborative practices with general education, or provide specificity related to collaborative performances in the teachers in ratings or comments.

Summary of elementary case study results. Results of data collected from elementary participant surveys, interviews, and text documents on research question one, suggests that collaborative practices are expected of the special education teacher candidate during student teaching, with the exception of co-teaching, and collaborative problem solving. Including the general education teacher as an equal in planning, delivery and assessment of student learning was not marked in the survey by either participant but was evident in the interview of the special education mentor teacher. The 
interview was consistent with two of the nine expectations from the survey: observe in general education classrooms, and coordinate meetings and progress monitoring.

Additional expectations emerged in the interview to include learning to manage behaviors and providing intensive instruction with small groups in general education classrooms. Text document analysis of the teaching work sample and student teaching evaluation did not reveal any expectations for collaborative practices or provide data on perspectives. Reflections on teaching did not include reflections on collaboration.

Data collected from elementary participants related to research question two revealed congruent perspectives on the importance of team building and establishing clear roles. This is consistent with the research in the literature review that states role ambiguity is a leading cause of breakdowns in collaboration (Brownell, et, al, 2005), and commitment to relationships as critical for successful collaboration (Cook, 2007).

An analysis of the typology of reflection revealed elementary special education mentor comments matched a comparative typology, where thoughts showed introspection and commitment to being open to different perspectives, but results did not show thinking about the broader implications of actions on students with disabilities, as described for 
critical thinking. The special education teacher candidate only described situations and did not demonstrate recognition of personal position or different perspectives.

\section{Middle School Special Education Case Study}

The middle school special education classroom is considered a self-contained life skills classroom where curriculum is focused on teaching students skills for independent self-care and living, to include accessing environments in the community. In a life skills classroom, the students are typically two or more grade levels behind their general education peers in multiple academic areas, and they need a high degree of assistance with daily tasks such as eating, dressing, and transitions. Academic and social skills instruction were focused on functional life routines more than grade-level curriculum and achieving a regular diploma. The students in the classroom were in $7^{\text {th }}$ through $9^{\text {th }}$ grade and had a wide range of disabilities in the range of moderate to severe to include: three students with Down Syndrome, three students with Autism, two with intellectual disabilities, and three with orthopedic impairments.

This middle school classroom had one lead teacher, and six instructional assistants. Three of the students were included in general education classrooms half of the day. The remaining eight students had significant disabilities, which means they required 
full assistance to take care of basic self-care and to access the school environment. This classroom is a guest classroom in the school, and is managed by the Education Service District (ESD). The ESD is contracted by the district to manage all life skills classrooms in the district.

Survey results of middle school participants. The survey results provided data in response to research question one, on the extent that middle school special education teacher candidates are expected to collaborate with general education teachers. Codes were based on predetermined categories and represented as + (yes) or - (no) to indicate if the collaborative practices were expected of the middle school special education teacher candidate during student teaching (Table 10). In the middle school case study, the special education teacher candidate reported more expectations of collaborative practice than her mentor teacher. Agreement was found between middle school participants in three of the eleven categories to include: identifying and communicating adaptations, including instructional assistants in collaborative plans, and observing in general education classrooms. The middle school participants were also in agreement there was no expectation of co-teaching, coordination of meetings and progress monitoring, or ensuring general education teachers had copies of IEPs. They differed in that the 
elementary special education teacher candidate had expectations of including general

education teachers as equal partners, sharing IEPs, involving general education teachers

in IEP planning and implementation, and coordination of assessments.

Table 10

Survey Results on Middle School Collaborative Practices

\begin{tabular}{|l|c|c|}
\hline Collaborative Practices & \multicolumn{2}{|c|}{ Middle School } \\
\hline & $\begin{array}{c}\text { Sped } \\
\text { Mentor } \\
\text { Teacher }\end{array}$ & $\begin{array}{c}\text { Sped } \\
\text { Teacher } \\
\text { Candidate }\end{array}$ \\
\hline $\begin{array}{l}\text { 1) Include the general education teacher as equal partner in planning, } \\
\text { delivery and assessment of student learning }\end{array}$ & - & + \\
\hline 2) Identify / communicate adaptations & + & + \\
\hline 3) Ensure copies of IEPs to address goals in general ed classroom & - & - \\
\hline 4) Involve gen ed in IEP development / implementation & - & + \\
\hline 5) Include instructional Asst. in collaborative plans & + & + \\
\hline 6) Observations in general education classrooms & + & + \\
\hline 7) Coordination of assessments with gen ed input and feedback & - & + \\
\hline 8) Coordination of meetings and progress monitoring with gen ed & - & - \\
\hline 9) Utilize knowledge of disabilities /instruction to facilitate gen ed access & + & - \\
\hline 10) Co-teach & - & - \\
\hline 11) Collaborative problem solving & - & + \\
\hline
\end{tabular}

Interviews with middle school participants. The interview results were

analyzed in response to research questions one and two. To determine the extent the

middle school special education teacher candidate was expected to collaborate with

general education teachers, text was coded from interviews using a deductive and

inductive analysis. Codes were used for interpretations of text based on the pre-

determined categories, and open coding allowed themes to emerge. Table 11 shows data 
results from codes of + (yes) or - (no) to indicate if there was a match between

participant responses to open-ended interview questions and the collaborative practices

identified by Cook and Friend (2007).

\section{Table 11}

Interview Results on Middle School Collaboration

\begin{tabular}{|c|c|c|}
\hline Collaborative Practices & MS sped Mentor Teacher & $\begin{array}{l}\text { MS sped Teacher } \\
\text { Candidate }\end{array}$ \\
\hline $\begin{array}{l}\text { 1) Include the general education } \\
\text { teacher as equal partner in } \\
\text { planning, delivery and assessment } \\
\text { of student learning }\end{array}$ & - & - \\
\hline $\begin{array}{l}\text { 2) Identify / communicate } \\
\text { adaptations }\end{array}$ & $\begin{array}{l}\text { + } \\
\text { I did try to connect with each } \\
\text { teacher and let them know what } \\
\text { the expectations for grades are. } \\
\text { they give me a syllabus of what } \\
\text { they are going to be teaching if } \\
\text { they have that. }\end{array}$ & $\begin{array}{l}+ \\
\text { directed only toward the Gen } \\
\text { Ed teachers that put forth } \\
\text { effort to integrate our } \\
\text { students with the Gen Ed } \\
\text { population }\end{array}$ \\
\hline $\begin{array}{l}\text { 3) Ensure copies of IEPs to } \\
\text { address goals in general ed } \\
\text { classroom }\end{array}$ & - & - \\
\hline $\begin{array}{l}\text { 4) Involve gen ed in IEP } \\
\text { development / implementation }\end{array}$ & - & - \\
\hline $\begin{array}{l}\text { 5) Include instructional Asst. in } \\
\text { collaborative plans }\end{array}$ & - & - \\
\hline $\begin{array}{l}\text { 6) Observations in general } \\
\text { education classrooms }\end{array}$ & $\begin{array}{l}+ \\
\text { I went into inclusion setting with } \\
\text { her and showed her how to do } \\
\text { things. }\end{array}$ & $\begin{array}{l}\qquad \\
\text { Many times I observed for } \\
\text { my Mentor teacher and } \\
\text { reported back to her on the } \\
\text { student's behavior and level } \\
\text { of engagement. } \\
\end{array}$ \\
\hline $\begin{array}{l}\text { 7) Coordination of assessments } \\
\text { with gen ed input and feedback }\end{array}$ & - & - \\
\hline $\begin{array}{l}\text { 8) Coordination of meetings and } \\
\text { progress monitoring with gen ed }\end{array}$ & - & + \\
\hline $\begin{array}{l}\text { 9) Utilize knowledge of } \\
\text { disabilities /instruction to } \\
\text { facilitate gen ed access }\end{array}$ & + & - \\
\hline 10) Co-teach & - & - \\
\hline $\begin{array}{l}\text { 11) Collaborative problem } \\
\text { solving }\end{array}$ & - & + \\
\hline
\end{tabular}


Based on the interviews with the middle school participants, there was consensus

the middle school special education teacher candidate was expected to do observations in general education classrooms, and identify/communicate adaptations to the general education teachers. These two expectations were consistent with the survey results, but expectations were identified in the survey results that were not captured in the interview. Table 12 shows additional themes related to collaborative practices, which were not included in the pre-determined categories, but emerged from an open-ended analysis of the interviews to include getting syllabi from general education teachers, educating general education teachers on expectations and definitions of collaboration and inclusion, and observing students with disabilities in a variety of general education classrooms.

Table 12

Emerging Themes from Middle School Interview

\begin{tabular}{|c|c|}
\hline $\begin{array}{l}\text { Middle school } \\
\text { special ed } \\
\text { mentor } \\
\text { teacher }\end{array}$ & $\begin{array}{l}\text { Expose general education teachers and students to kids with different levels of } \\
\text { ability and value them as part of the community } \\
\text { General education teachers need to hear from the special education teacher what } \\
\text { collaboration and inclusion means } \\
\text { - Inform general education teachers about expectations for grading students with } \\
\text { disabilities } \\
\text { - Get syllabi if available }\end{array}$ \\
\hline $\begin{array}{l}\text { Middle school } \\
\text { special ed } \\
\text { teacher } \\
\text { candidate }\end{array}$ & 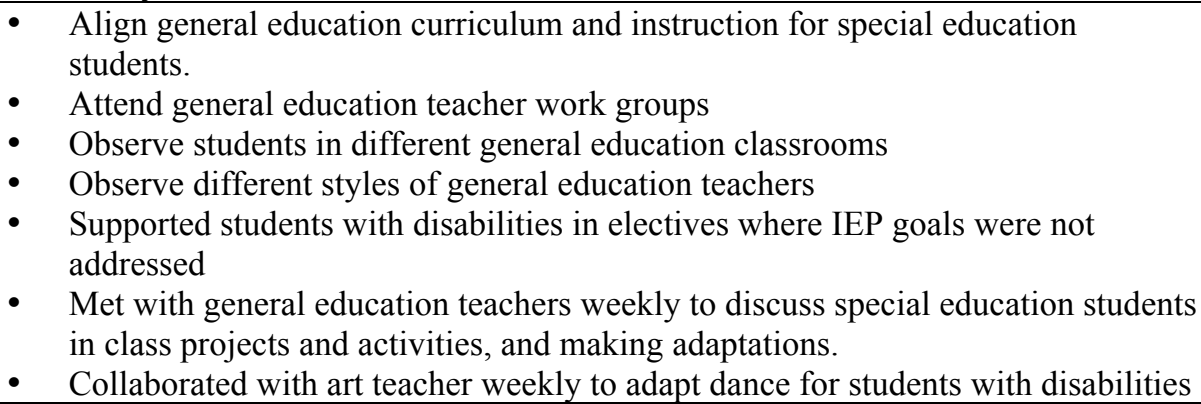 \\
\hline
\end{tabular}


Middle school follow-up interview. Due to the different pattern in the results at the middle school data compared with other settings, a follow-up phone interview was done with both the middle school mentor teacher and the middle school special education teacher candidate to confirm survey and interview responses. On the survey, the middle school mentor teacher reported lower expectations than the middle school teacher candidate on both the survey and interview measures, which was flipped from results in other settings. The middle school mentor teacher confirmed there was no expectation in the categories marked on the survey stating, "Collaboration is definitely something that as a special education teacher it's not your primary concern, cause there is so much going on. I went into the inclusion setting with her and showed how I would do things, and modeled for her what is expected in that setting" (middle school mentor teacher interview, 2012). The middle school teacher candidate reported regular collaboration with the art and drama teachers, stating, "My mentor teacher did encourage me to work with the general ed teacher in planning, delivery and assessment" (Middle school teacher candidate interview, 2012). In the second interview, the middle school teacher candidate reported her perspective on collaboration changed as a result of a course taken in the teacher education program prior to student teaching. 
We (special education teacher candidates) had the class, which emphasized the importance of it, and I have to say I never thought of some things as collaboration before that class. I didn't realize the importance of how specific and purposeful it really should be, and the conversation of how it should be directly related to the kids. I saw working with two teachers how it was related to the kids, and not the other, and the effectiveness of that. Having that class was a plus. (MS teacher candidate interview)

The middle school mentor teacher made a distinction in the interview between collaboration and communication that was not apparent in the interview with the middle school special education teacher candidate. The middle school special education mentor teacher referred to communication as checking in, and collaboration as a thorough examination of the curriculum, what's working, not working, and what could be adapted.

Middle school participant perspectives. Table 13 shows themes that surfaced from interview responses of middle school mentor teacher and special education teacher candidate. The middle school mentor teacher and middle school special education teacher candidate were not in alignment on any responses. The middle school mentor teacher emphasized communication, understanding different student needs, and learning about obstacles in administration, while the middle school special education teacher candidate emphasized the need to experience different general education settings, and adapt curriculum and instruction for general education classrooms and curriculum. They 
differed slightly in what they perceived as their role and the role of collaboration in

meeting the needs of students with disabilities.

Table 13

Middle School Participant Perspectives

\begin{tabular}{|c|c|c|c|}
\hline Interview questions & MS Sped Mentor Teacher & $\begin{array}{l}\text { MS Sped Teacher } \\
\text { Candidate }\end{array}$ & Congruence \\
\hline $\begin{array}{l}\text { What's important } \\
\text { about collaboration? }\end{array}$ & $\begin{array}{l}\text { For general education teachers to } \\
\text { see benefits for typical students } \\
\text { For general education teachers and } \\
\text { students to be exposed to kids with } \\
\text { different levels of ability and value } \\
\text { them as part of the community }\end{array}$ & $\begin{array}{l}\text { For the special education } \\
\text { teacher to align general } \\
\text { education curriculum } \\
\text { and instruction for } \\
\text { special education } \\
\text { students. }\end{array}$ & - \\
\hline $\begin{array}{l}\text { How does } \\
\text { collaboration help } \\
\text { students with } \\
\text { disabilities? }\end{array}$ & $\begin{array}{l}\text { Each teacher and environment is } \\
\text { different } \\
\text { General education teachers need to } \\
\text { hear from the special education } \\
\text { teacher what collaboration and } \\
\text { inclusion means }\end{array}$ & $\begin{array}{l}\text { It helps to raise } \\
\text { expectations and prepare } \\
\text { students in special } \\
\text { education for the real } \\
\text { world }\end{array}$ & - \\
\hline $\begin{array}{l}\text { What makes } \\
\text { collaboration with } \\
\text { general education } \\
\text { teachers successful? }\end{array}$ & $\begin{array}{l}\text { Inclusion is not always successful } \\
\text { Need to provide a continuum of } \\
\text { placement options depending on } \\
\text { needs of the student }\end{array}$ & $\begin{array}{l}\text { Being open to ideas } \\
\text { Building a relationship } \\
\text { Being respectful of goals } \\
\text { for different } \\
\text { environments } \\
\text { Build goals and } \\
\text { adaptations into class so } \\
\text { student has authentic } \\
\text { work and sense of } \\
\text { belonging }\end{array}$ & - \\
\hline $\begin{array}{l}\text { What are the } \\
\text { challenges to } \\
\text { collaboration with } \\
\text { general education } \\
\text { teachers }\end{array}$ & $\begin{array}{l}\text { Being disconnected from being part } \\
\text { of professional development, staff } \\
\text { meetings, and communication } \\
\text { systems with other teachers in the } \\
\text { school } \\
\text { Different systems and } \\
\text { administrators }\end{array}$ & $\begin{array}{l}\text { Conflicting priorities, } \\
\text { Adapting curriculum and } \\
\text { instruction, } \\
\text { Time for collaboration }\end{array}$ & - \\
\hline $\begin{array}{l}\text { What do you see as } \\
\text { the role of special } \\
\text { education teachers } \\
\text { in fostering } \\
\text { collaboration with } \\
\text { general education } \\
\text { teachers? }\end{array}$ & $\begin{array}{l}\text { Communicate through email } \\
\text { Inform general education teachers } \\
\text { about expectations for grading } \\
\text { students with disabilities } \\
\text { Check in weekly and quarterly } \\
\text { Get syllabi if available } \\
\text { Make it possible for students with } \\
\text { disability to get exposure to general } \\
\text { education classrooms and } \\
\text { curriculum }\end{array}$ & $\begin{array}{l}\text { Foster collaboration } \\
\text { (sped are go betweens) } \\
\text { To help students with } \\
\text { disabilities in general } \\
\text { education classrooms } \\
\text { Plan adaptations with } \\
\text { general education } \\
\text { teachers } \\
\text { Attend general education } \\
\text { teacher work groups }\end{array}$ & - \\
\hline
\end{tabular}


Table 13. (continued)

\begin{tabular}{|c|c|c|c|}
\hline Interview questions & MS Sped Mentor Teacher & $\begin{array}{l}\text { MS Sped Teacher } \\
\text { Candidate }\end{array}$ & Congruence \\
\hline $\begin{array}{l}\text { (Mentor) What is } \\
\text { important for } \\
\text { special education } \\
\text { candidates to learn } \\
\text { about collaboration } \\
\text { during student } \\
\text { teaching? }\end{array}$ & $\begin{array}{l}\text { To invest in communication } \\
\text { To reach out to general education } \\
\text { teachers } \\
\text { Learn to manage different student } \\
\text { needs and prioritize } \\
\text { Importance of getting familiar with } \\
\text { administration and teachers before } \\
\text { year gets started } \\
\text { How to direct and train education } \\
\text { assistants }\end{array}$ & $\begin{array}{l}\text { What more would you } \\
\text { like to have learned } \\
\text { about collaboration? } \\
\text { To see more kids in } \\
\text { different general } \\
\text { education classrooms } \\
\text { and see different styles } \\
\text { of general education } \\
\text { teachers and different } \\
\text { environments }\end{array}$ & - \\
\hline
\end{tabular}

The middle school special education teacher talked about collaboration in the

context of inclusion for the purpose of exposing general education teachers and students

to students with disabilities, and for students with disabilities to be in general education

classrooms for exposure to general education curriculum. Also mentioned were the

limitations on collaboration as a result of separate administration, schedules, and

incompatible email systems. The middle school special education teacher reported that

general education teachers need to know the mission of special education, need to know

what inclusion means, and need to know they don't have to do anything special for the

students in special education because the special education teacher will take care of the

special education students. 
In contrast, the middle school special education teacher viewed the purpose of collaboration to align curriculum, raise expectations, and build goals and adaptations into the general education classroom. Challenges noted were time to meet, conflicting priorities, and knowing how to adapt and modify curriculum and instruction in general education classrooms. The middle school special education teacher candidate believed success of collaboration requires an attitude of openness, an understanding of the different needs of teachers, environments and teachers, building relationships, and being respectful.

Middle school typologies of reflection. Table 14 gives an example of typology of reflection of the middle school mentor and the middle school special education teacher candidate. The reflections of the middle school special education teacher were descriptive. An example of the text shows problems were described with a lack of understanding of other perspectives and a bigger picture connected to ideas for improving the situation. In contrast, the middle school special education teacher candidate provided comparative reflections that included interpretations of the actions of others, comparisons, and awareness of own role in the situation. 


\section{Table 14}

\section{Typology of Reflection Narratives: Middle School}

\begin{tabular}{|c|c|c|}
\hline & $\begin{array}{l}\text { Middle School Sped Mentor } \\
\text { Teacher }\end{array}$ & Middle School Sped Teacher Candidate \\
\hline $\begin{array}{l}\text { How is disposition } \\
\text { reflected in } \\
\text { language that } \\
\text { describes } \\
\text { collaboration? } \\
\text { (typology of } \\
\text { reflection) }\end{array}$ & $\begin{array}{l}\text { Descriptive } \\
\text { The ESD with their own separate } \\
\text { trainings and inservices and } \\
\text { teacher development and so forth } \\
\text { often don't coincide or conflict with } \\
\text { staff development days that are in } \\
\text { the building and leads to missed } \\
\text { opportunities to collaboration } \\
\text { within the building. That's always } \\
\text { been a challenge for me. I have } \\
\text { expressed my concerns about that. } \\
\text { They get to know each other at the } \\
\text { beginning of the school year and } \\
\text { we are not in the building, and that } \\
\text { is my main concern. } \\
\text { Collaboration depends on the } \\
\text { attitude of the general education } \\
\text { teacher. It becomes more of a } \\
\text { challenge if they have } 30-40 \text { kids in } \\
\text { their classroom and looking at the } \\
\text { range of ability in that group then } \\
\text { there are my kids so different from } \\
\text { that. I try to do most of that, I am } \\
\text { constantly telling them they don't } \\
\text { have to worry about this child not } \\
\text { getting that content and that child } \\
\text { is doing the best they can in that } \\
\text { environment, and to modify the } \\
\text { curriculum. }\end{array}$ & $\begin{array}{l}\text { Comparative } \\
\text { If the student had a question and raised } \\
\text { their hand she would refer them to } \\
\text { another student for help. That told her } \\
\text { she was not so important. To me that } \\
\text { was not effective collaboration. That } \\
\text { was a touchy and uncomfortable } \\
\text { situation and I don't' think the student } \\
\text { got a lot out of it. She was a good } \\
\text { teacher with the general education } \\
\text { students but didn't really relate or take } \\
\text { the time to get to know the special needs } \\
\text { kids that were in her class. It was } \\
\text { apparent to me, but I don't know how } \\
\text { students felt about it. As an adult in } \\
\text { there, I saw } 20 \text { minutes at a time they } \\
\text { were working independently and not } \\
\text { under her guidance. }\end{array}$ \\
\hline
\end{tabular}

Middle school document analysis. A content analysis was done in field-based

documents in the elementary setting to include the Student Teaching Work Sample and

the Student Teaching Evaluation. The middle school work sample had one target student

for instruction. The student was female, had intellectual disabilities, was in the $6^{\text {th }}$ grade, 
and had overall academic skills at the third grade level. The work sample topic was counting change. The student's IEP indicated she was to receive communication skills instruction for 20 minutes per day in either the general or special education classroom. In addition, she was to receive social skills instruction in the general education or special education classroom 15 minutes per week. It was noted in the work sample that this student "is open and friendly and enjoys her inclusive classes with the general education students" (work sample document, pg. 10). The middle school special education teacher candidate wrote in one reflection that her students join general education students the last two periods of each day after lunch. The work sample consisted of 111 pages of description, templates, graphs, and reflections. There was no evidence in the work sample of communication or collaboration with general education teachers.

The Student Teaching Summary Evaluation is a rating scale of teaching effectiveness aligned with TSPC standards, completed by the middle school special education mentor teacher and the university supervisor in the middle and at the end of the 12-week student teaching experience to document meeting standards. The evaluation included broad measures of collaboration, but there was no clear evidence that showed the middle school special education teacher candidate engaged in the collaborative 
practices identified in the research. There was a general expectation to share information and interact and advise with others, but it did not clearly match the collaborative practices with general education, or provide specificity related to collaborative performances in the ratings or comments.

\section{Summary of middle school case study results. Data collected from middle}

school participant surveys, interviews, and text documents on research question one, showed agreement that three of the eleven collaborative practices are expected of middle school special education teacher candidates during student teaching: identifying adaptations, observing in general education classrooms, and including instructional assistants in collaborative plans. The interview results corroborated with only one of these three: observing in general education classrooms. Additional expectations emerged in the interview to include: getting syllabi from general education teachers, educating general education teachers on expectations and definitions of collaboration and inclusion, and observing students with disabilities in a variety of general education classrooms. Text document analysis of the teaching work sample and student teaching evaluation did not reveal any expectations for collaborative practices. The middle school special education teacher candidate reported a wider range of expectations and experiences with 
collaborative practices, beyond what was expected by the middle school special education mentor teacher.

Data collected from middle school participants related to research question two revealed no similarity in perspectives. The middle school special education mentor teacher described the primary goal of collaboration as for the benefit of general education teachers. She viewed her role as helping general education teachers be exposed to kids with different disabilities and levels of ability. She believed most important was the benefit to general education students to learn how students with severe disabilities can be a functional and valuable part of the community. The special education mentor teacher did not express goals for raising standards or academic achievement of the student in her classroom. Inclusion and collaboration was more for the benefit of general education teachers and students than for students with disabilities. In contrast, the middle school special education teacher candidate saw the purpose of collaboration to provide access to general education curriculum and instruction for students with disabilities, to raise standards, and to prepare students for the future.

An analysis of the typology of reflection revealed the middle school special education mentor used descriptive reflections to explain barriers to communication and 
collaboration. She listed obstacles such as email blocks, different professional

development, and lack of awareness of special education on behalf of general education teachers as barriers, without considering other perspectives, implications of these barriers, or taking responsibility for change. The special education teacher candidate's text matched a comparative typology, where thoughts showed openness to different perspectives commitment to students with disabilities.

\section{High School Special Education Case Study}

The high school special education classroom is described by the special education mentor as resource room for students with disabilities who have a range of mild to moderate academic support needs. The primary goal of the classroom is to provide academic development and intervention in reading, writing, and math to students on IEPs who struggle in general education classrooms. The curriculum and IEPs are guided by the state common core standards, and a primary goal is to prepare students to for state testing and to achieve a standard high school diploma.

As many as 25 students in grades 9-12 are served through the resource room in 60-90 minute class periods that are coordinated around general education class schedules. Most of the students are in general education classrooms at least $80 \%$ of the day. Students 
in the classroom have a range of needs and disabilities to include: Intellectual Disability,

Other Health Impaired/Attention Deficit Disorder, Emotional Disturbance, Learning

Disability, and Autism. Some of the students have social-emotional issues, which

impedes learning in the general education classrooms. The middle school resource room

has one full time special education teacher and one full time teaching assistant.

Survey Results of High School Participants. The survey identified the extent

the high school special education teacher candidate was expected to collaborate with

general education teachers. Codes were based on predetermined categories and

represented as + (yes) or - (no) to indicate if the collaborative practices were expected of

the high school special education teacher candidate (Table 15).

Table 15

Survey Results on High School Collaborative Practices

\begin{tabular}{|l|c|c|}
\hline Collaborative Practices & \multicolumn{2}{|c|}{ High School } \\
\hline & $\begin{array}{c}\text { HS Sped } \\
\text { Mentor } \\
\text { Teacher }\end{array}$ & $\begin{array}{c}\text { HS Sped } \\
\text { Teacher } \\
\text { Candidate }\end{array}$ \\
\hline $\begin{array}{l}\text { 1) Include the general education teacher as equal partner in planning, } \\
\text { delivery and assessment of student learning }\end{array}$ & + & + \\
\hline 2) Identify / communicate adaptations & + & + \\
\hline 3) Ensure copies of IEPs to address goals in general ed classroom & + & - \\
\hline 4) Involve gen ed in IEP development / implementation & + & - \\
\hline 5) Include instructional Asst. in collaborative plans & + & - \\
\hline 6) Observations in general education classrooms & - & - \\
\hline 7) Coordination of assessments with gen ed input and feedback & + & + \\
\hline 8) Coordination of meetings and progress monitoring with gen ed & + & + \\
\hline 9) Utilize knowledge of disabilities /instruction to facilitate gen ed access & + & + \\
\hline 10) Co-teach & - & - \\
\hline 11) Collaborative problem solving & + & + \\
\hline
\end{tabular}


In the high school case study, the special education teacher candidate reported fewer expectations for collaboration than his mentor teacher. The high school case study participants were in agreement that six of the eleven collaborative practices are an expectation during student teaching to include: identifying and communicating adaptations, including the general education teacher as an equal partner in planning, delivery and assessment of student learning, coordinating assessments and feedback, collaborative problem solving, coordination of meetings and progress monitoring, and utilizing knowledge of disabilities to facilitate access to general education curriculum and classrooms. The high school participants were also in agreement there was no expectation of observing in general education classrooms and co-teaching. They differed in that the high school special education mentor teacher had expectations that the special education high school teacher candidate share IEPs with general education teachers, and include general education teachers in developing and implementing IEPs, but these were not noted expectations of the high school special education teacher candidate.

Interview with high school participants. The interview results were analyzed in response to research questions one and two. Text was coded from interviews using deductive and inductive analysis to determine the extent that the high school special 
education teacher candidate was expected to collaborate with general education teachers.

Codes were applied to interpretations of text based on the pre-determined categories and

new categories created from themes that emerged. Table 16 shows data results

represented from coding as + (yes) or - (no) to indicate if there was a match between

participant responses to open-ended interview questions and the collaborative practices

identified by Cook and Friend (2007).

Table 16

Interview Results on High School Collaboration

\begin{tabular}{|c|c|c|}
\hline & HS sped mentor teacher & $\begin{array}{l}\text { HS sped teacher } \\
\text { candidate }\end{array}$ \\
\hline $\begin{array}{l}\text { 1) Include the general } \\
\text { education teacher as equal } \\
\text { partner in planning, } \\
\text { delivery and assessment of } \\
\text { student learning }\end{array}$ & $\begin{array}{l}+ \\
\text { Toward the end, the last 2-3 } \\
\text { weeks, I made him go out to } \\
\text { classrooms and we discussed } \\
\text { what happened and how to } \\
\text { improve learning }\end{array}$ & $\begin{array}{l}+ \\
\text { Mostly general education teachers } \\
\text { came down to the resource room } \\
\text { and talked about how kids were } \\
\text { performing in class an asked for } \\
\text { suggestions. I went to gen ed } \\
\text { classes too to find out what tests } \\
\text { they needed to work on. }\end{array}$ \\
\hline $\begin{array}{l}\text { 2) Identify / communicate } \\
\text { adaptations }\end{array}$ & $\begin{array}{l}\text { Every day I meet with a } \\
\text { language arts teacher, a } \\
\text { science teacher, a math } \\
\text { teacher. Somewhere in the } 8 \\
\text { hours we are here we are } \\
\text { going in asking questions, } \\
\text { collaborating with them, } \\
\text { where are we moving to next, } \\
\text { what can we do to } \\
\text { supplement or help with } \\
\text { assignments. }\end{array}$ & $\begin{array}{c}+ \\
\text { I primarily talked about adapting } \\
\text { tests and homework. My mentor } \\
\text { teacher already talked to them } \\
\text { about adaptations and } \\
\text { modifications (earlier in the school } \\
\text { year) }\end{array}$ \\
\hline $\begin{array}{l}\text { 3) Ensure copies of IEPs to } \\
\text { address goals in general ed } \\
\text { classroom }\end{array}$ & + & - \\
\hline $\begin{array}{l}\text { 4) Involve gen ed in IEP } \\
\text { development / } \\
\text { implementation }\end{array}$ & - & + \\
\hline
\end{tabular}


Table 16. (continued)

\begin{tabular}{|c|c|c|}
\hline & HS Sped Mentor & HS Sped Teacher Candidate \\
\hline $\begin{array}{l}\text { 5) Include instructional } \\
\text { Asst. in collaborative plans }\end{array}$ & - & - \\
\hline $\begin{array}{l}\text { 6) Observations in general } \\
\text { education classrooms }\end{array}$ & + & - \\
\hline $\begin{array}{l}\text { 7) Coordination of } \\
\text { assessments with gen ed } \\
\text { input and feedback }\end{array}$ & $\begin{array}{c}+ \\
\text { We are really on top of where } \\
\text { these kids are and collecting } \\
\text { the data }\end{array}$ & $\begin{array}{l}\text { We did a lot of ...... skill mastery } \\
\text { tests, to pass the classes they had to } \\
\text { pass } 17 \text { of these tests in the course } \\
\text { of the school year. }\end{array}$ \\
\hline $\begin{array}{l}\text { 8) Coordination of } \\
\text { meetings and progress } \\
\text { monitoring with gen ed }\end{array}$ & $\begin{array}{l}+ \\
\text { He got to observe a lot of } \\
\text { collaboration with me. He } \\
\text { presented himself well. He } \\
\text { didn't always get the answer } \\
\text { he wanted and we talked } \\
\text { about that we need to explain } \\
\text { what we are trying to } \\
\text { accomplish. }\end{array}$ & $\begin{array}{l}+ \\
\text { Mostly I was down in the resource } \\
\text { room and they would come down } \\
\text { and check in. }\end{array}$ \\
\hline $\begin{array}{l}\text { 9) Utilize knowledge of } \\
\text { disabilities /instruction to } \\
\text { facilitate gen ed access }\end{array}$ & $\begin{array}{l}\quad+ \\
\text { Sometimes we address a } \\
\text { direct team with specific } \\
\text { problems. Every day I meet } \\
\text { with a language arts teacher, } \\
\text { a science teacher, a math } \\
\text { teacher. }\end{array}$ & $\begin{array}{c}+ \\
\text { General ed teacher came down and } \\
\text { asked questions and invited us to } \\
\text { come into his class and participate } \\
\text { when we could to see how the kids } \\
\text { were doing and help if needed so } \\
\text { he could better serve those } \\
\text { students. }\end{array}$ \\
\hline 10) Co-teach & - & - \\
\hline $\begin{array}{l}\text { 11) Collaborative problem } \\
\text { solving }\end{array}$ & $\begin{array}{l}+ \\
\text { He did have a couple bumps } \\
\text { in the road (when } \\
\text { collaborating) and he tucked } \\
\text { his tail and ran because he } \\
\text { wasn't prepared for the no. }\end{array}$ & $\begin{array}{l}\quad+ \\
\text { A math teacher provided tests and } \\
\text { assumed it was our responsibility } \\
\text { to sore and track students, and that } \\
\text { was just for special education } \\
\text { students. That was a } \\
\text { disappointment. }\end{array}$ \\
\hline
\end{tabular}

Based on the interviews with the high school participants, there was consensus

that the high school special education teacher candidate was expected to include general

education teachers as equal partners in planning, teaching and assessment of students

with disabilities, identify adaptations, coordinate assessment, be a resource, coordinate 
meetings and progress monitoring, and participate in collaborative problem solving.

These expectations were consistent with the survey results. Table 17 lists additional

themes that emerged related to collaborative practices from high school participant

interviews to include: learning skills for communication, experiencing different ways of

collaborating with different general education teachers, different students, and in different

environments, and documenting or reflecting on observations and experiences related to

collaboration.

\section{Table 17}

Emerging Themes from High School Interview

\begin{tabular}{|c|c|}
\hline $\begin{array}{l}\text { High school } \\
\text { special } \\
\text { education } \\
\text { mentor } \\
\text { teacher }\end{array}$ & 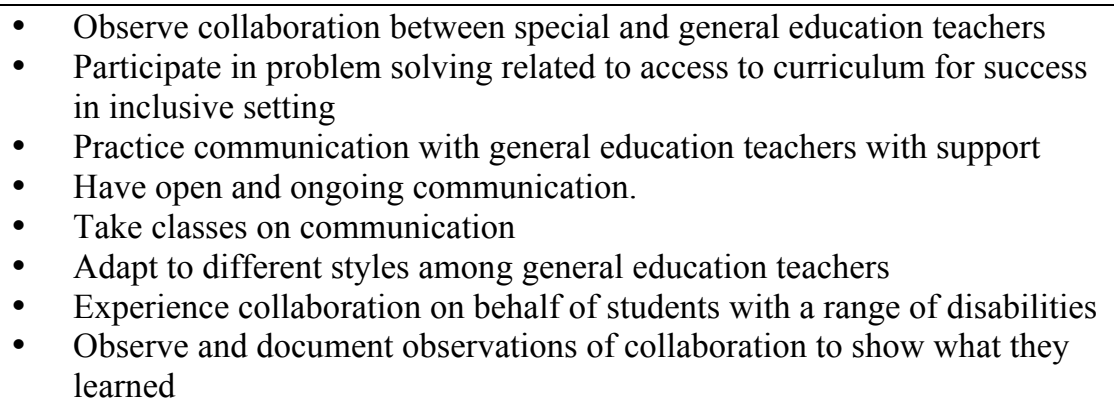 \\
\hline $\begin{array}{l}\text { High school } \\
\text { special } \\
\text { education } \\
\text { teacher } \\
\text { candidate }\end{array}$ & $\begin{array}{l}\text { Teamed with mentor to talk with general education teachers regularly } \\
\text { about progress, tests, and needs of students in special education. } \\
\text { - Used common core state standards as reference for interventions in } \\
\text { general education classrooms } \\
\text { Be responsive to the needs and perspectives of different general education } \\
\text { teachers }\end{array}$ \\
\hline
\end{tabular}

High school participant perspectives. Table 18 shows strong alignment between

the perspectives of the high school special education mentor and teacher candidate to 
include: collaboration as a benefit to post-school student life, general and special

education teacher teamwork, as a service to general education teachers, and the

importance of open dialogue and communication.

\section{Table 18}

\section{High School Participant Perspectives}

\begin{tabular}{|c|c|c|c|}
\hline Interview questions & HS Sped Mentor Teacher & $\begin{array}{l}\text { HS Sped Teacher } \\
\text { Candidate }\end{array}$ & Congruence \\
\hline $\begin{array}{l}\text { What's important } \\
\text { about collaboration } \\
\text { with general } \\
\text { education teachers? }\end{array}$ & Must be student-centered & $\begin{array}{l}\text { Purpose of collaboration is } \\
\text { to support access to LRE }\end{array}$ & - \\
\hline $\begin{array}{l}\text { How does } \\
\text { collaboration with } \\
\text { general education } \\
\text { teachers help } \\
\text { students with } \\
\text { disabilities? }\end{array}$ & $\begin{array}{l}\text { Teachers need to be united } \\
\text { in eyes of students } \\
\text { Students with disabilities } \\
\text { need chance to get a regular } \\
\text { diploma }\end{array}$ & $\begin{array}{l}\text { Helps inclusion be } \\
\text { successful, which is good } \\
\text { for self-esteem and adult } \\
\text { life for students with } \\
\text { disabilities }\end{array}$ & + (adult life) \\
\hline $\begin{array}{l}\text { What makes } \\
\text { collaboration with } \\
\text { general education } \\
\text { teachers successful? }\end{array}$ & $\begin{array}{l}\text { Sped teachers need to be a } \\
\text { servant, be humble, be a } \\
\text { resource, } \\
\text { be accessible, } \\
\text { Supportive administration } \\
\text { Sharing information } \\
\text { Regular communication }\end{array}$ & $\begin{array}{l}\text { Takes teamwork. } \\
\text { Changes made for sped can } \\
\text { benefit gen ed students as } \\
\text { well. } \\
\text { Keep communication open } \\
\text { Stay positive. flexible } \\
\text { Be organized }\end{array}$ & $\begin{array}{c}+ \text { (sharing / } \\
\text { teamwork, } \\
\text { regular } \\
\text { communication })\end{array}$ \\
\hline $\begin{array}{l}\text { What are the } \\
\text { challenges to } \\
\text { collaboration with } \\
\text { general education } \\
\text { teachers }\end{array}$ & $\begin{array}{l}\text { Working together to help all } \\
\text { students meet standards } \\
\text { Conflicting goals }\end{array}$ & $\begin{array}{l}\text { Time it takes to collaborate } \\
\text { and plan. } \\
\text { Buy in from general ed } \\
\text { teachers to do things } \\
\text { differently }\end{array}$ & $\begin{array}{l}+ \text { (working } \\
\text { together/conflict } \\
\text { ing goals / buy } \\
\text { in) }\end{array}$ \\
\hline $\begin{array}{l}\text { What do you see as } \\
\text { the role of special } \\
\text { education teachers in } \\
\text { fostering } \\
\text { collaboration with } \\
\text { general education } \\
\text { teachers? }\end{array}$ & $\begin{array}{l}\text { Provide support in general } \\
\text { education classrooms } \\
\text { Provide support and } \\
\text { strategies in the content } \\
\text { areas } \\
\text { Differentiate, adapt } \\
\text { curriculum and instruction } \\
\text { to meet IEP objectives }\end{array}$ & $\begin{array}{l}\text { Create understanding, } \\
\text { Identify struggling students } \\
\text { Educate gen ed teachers } \\
\text { about disabilities } \\
\text { Establish communication, } \\
\text { Be positive, } \\
\text { Be a service to gen ed } \\
\text { teachers }\end{array}$ & $\begin{array}{l}+ \text { (support } \\
\text { general } \\
\text { education } \\
\text { teachers) }\end{array}$ \\
\hline
\end{tabular}


Table 18. (continued)

\begin{tabular}{|c|c|c|c|}
\hline Interview questions & HS Sped Mentor Teacher & $\begin{array}{l}\text { HS Sped Teacher } \\
\text { Candidate }\end{array}$ & Congruence \\
\hline $\begin{array}{l}\text { What is important for } \\
\text { special education } \\
\text { candidates to learn } \\
\text { about collaboration } \\
\text { during student } \\
\text { teaching? }\end{array}$ & $\begin{array}{l}\text { Intrapersonal and } \\
\text { interpersonal } \\
\text { communication } \\
\text { Make student-centered } \\
\text { decisions } \\
\text { Adapt to different general } \\
\text { education teachers } \\
\text { Need field experience } \\
\text { collaborating on behalf of } \\
\text { students with a range of } \\
\text { disabilities }\end{array}$ & $\begin{array}{l}\text { What more would you like } \\
\text { to have learned about } \\
\text { collaboration? } \\
\text { More opportunity to see } \\
\text { open dialogue and } \\
\text { collaborative planning for } \\
\text { classes }\end{array}$ & $\begin{array}{c}+ \text { (open } \\
\text { dialogue/ } \\
\text { communication) }\end{array}$ \\
\hline
\end{tabular}

The high school mentor teacher identified characteristics believed to be essential

for the special education teacher candidate to include being humble, student-centered,

and accessible. The high school special education mentor noted challenges to

collaboration as related to accountability and finding ways all students could meet state

standards. This was not identified as a challenge to the teacher candidate, but the teacher

candidate did recognize how tension exists from conflicting goals between general and

special education teachers. Time for collaboration was mentioned as a need by both the

high school special education mentor and teacher candidate, but in response to different

interview questions. Both the high school mentor and special education teacher candidate

mentioned communication skills as an essential component of collaboration. 
High school typologies of reflection. Reflections from high school case study

interviews and text documents were analyzed and matched using typology of reflection

rubric (Table 19). Text documents did not show evidence of reflection on collaboration.

The high school mentor teacher interview transcription met criteria for critical reflection.

In his comments he advocated for the rights of students with disabilities and considered

implications of students with disabilities not achieving a standard high school diploma.

He consistently thought about ways to take responsibility for student achievement and

improve education for students with disabilities. The high school special education

teacher candidate reflections met comparative criteria for recognizing perspectives and

challenges of general education teachers.

Table 19

Typology of Reflection Narratives: High School

\begin{tabular}{|c|c|c|}
\hline & High School Sped Mentor Teacher & $\begin{array}{l}\text { High School Sped Teacher } \\
\text { Candidate }\end{array}$ \\
\hline $\begin{array}{l}\text { How is disposition } \\
\text { reflected in language } \\
\text { that describes } \\
\text { collaboration? } \\
\text { (typology of } \\
\text { reflection) }\end{array}$ & $\begin{array}{l}\text { Critical reflections } \\
\text { Ifight for my kids to reach for the } \\
\text { regular diploma. A student in } \\
\text { special ed can go to school until } \\
\text { they are } 21 \text {. Our school district } \\
\text { doesn't have anything set up for the } \\
\text { mild moderate. We have it for the } \\
\text { severe students but I think if we had } \\
\text { something set up and students could } \\
\text { be told early on they are in special } \\
\text { ed and what we are going to do to } \\
\text { help them prepare for life. }\end{array}$ & $\begin{array}{l}\text { Comparative reflections, } \\
\text { It's important to communicate, and } \\
\text { for gen ed teachers to be open and } \\
\text { willing to try new things they have } \\
\text { not tried before, and at the same } \\
\text { time it's important for special } \\
\text { educators to listen to concerns and } \\
\text { do the best they can to assist the } \\
\text { regular ed teachers in terms of } \\
\text { making adaptations and } \\
\text { modifications. }\end{array}$ \\
\hline
\end{tabular}


High school document analysis. A content analysis was done on the high school Student Teaching Work Sample and the Student Teaching Evaluation. The high school work sample included documented planning, teaching, and assessment of teaching four male students who attended the resource room one period per day for reading and math support. Two of the students were in the $10^{\text {th }}$ grade, one was in the $9^{\text {th }}$ grade, and one was in the $11^{\text {th }}$ grade. The topic of the work sample was identifying main idea in a chapter book. The topic was selected based on the remedial curriculum that was already established in the resource room. The work sample consisted of 105 pages of description, templates, graphs, and reflections. There was no evidence of communication or collaboration with general education teachers in relation to the collaborative practices throughout the work sample, including when selecting a topic or goal for instruction, assessment, or learning. There was reference to relevant state standards, but no evidence that content being taught in the resource room was connected with general education curriculum.

The Student Teaching Summary Evaluation is a rating scale of teaching effectiveness aligned with TSPC standards, completed by the high school special education mentor teacher and the university supervisor in the middle and at the end of the 
12-week student teaching experience to document meeting standards. The evaluation included broad measures of collaboration, but there was no clear evidence that showed the middle school special education teacher candidate engaged in the collaborative practices identified in the research. There was a general expectation to share information and interact and advise with others, but it did not clearly match the collaborative practices with general education, or provide specificity related to collaborative performances in the ratings or comments.

Summary of high school case study results. Data collected from high school participant surveys, interviews, and text documents on research question one, suggests that collaborative practices are expected of the high school special education teacher candidate during student teaching, with the exception of co-teaching, and observing in the general education classroom. There were many opportunities for the special education teacher candidate to collaborate with general education teachers, and observations in general education classrooms were apparent in the interview but marked as not happening on the survey.

Additional expectations emerged in the interview to include: learning skills for communication, experiencing different ways of collaborating with different general 
education teachers, students, and environments, and documenting or reflecting on observations and experiences related to collaboration. Text document analysis of the Teaching Work sample and Student Teaching Evaluation did not reveal any expectations for collaborative practices.

Data collected from high school participants related to research question two revealed congruent perspectives on the importance of being flexible, student-centered, accessible, and committed to regular communication. There was a shared focus on preparing students with disabilities for a regular diploma to the greatest extent possible, and preparing them for life after high school.

An analysis of the typology of reflection of high school participants identified the high school special education mentor reflections as matching critical reflection criteria on the typology rubric. The high school special education teacher candidate reflections matched the comparative criteria. Both participants expressed a strong belief and commitment to collaboration as a benefit to both students and teachers. The critical reflections of the high school mentor demonstrate a sense of agency for creating and sustaining systems that best support ways to help students with disabilities be successful in general education settings. 


\section{Comparison of Collaborative Practices Across Settings}

Figure 4 shows the results of the survey and interview instruments from all

participants combined in each collaborative practice category. The graph shows

consistent matches on the two instruments in two of the eleven questions. The survey and interview results are consistent in indicating no expectation of co-teaching across

settings. In question five, utilizing instructional assistants in collaborative practices, the interviews showed no expectation, but this was identified as a yes on the survey in 5 out of 6 responses. For most questions, the survey instrument reflects a greater or equal degree of expectation than the interview, with the exception of question one, including the general education teacher as an equal partner, and eight, participating in meetings and progress monitoring. Figure 5 looks at survey and interview responses of special education mentors across settings on the extent of collaborative practices for special education teacher candidates. All three mentor teachers had an expectation for identifying and communicating adaptations, and no expectation for co-teaching on both survey and interview instruments. 


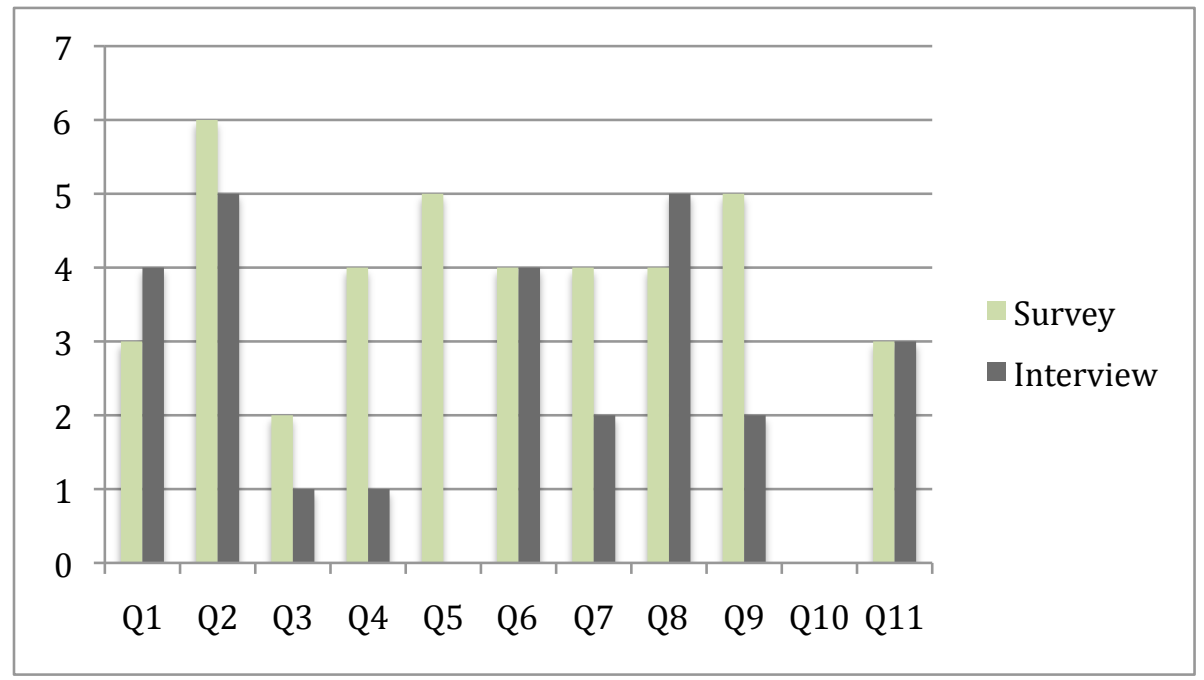

Figure 4. Instrument results of collaborative practice categories.

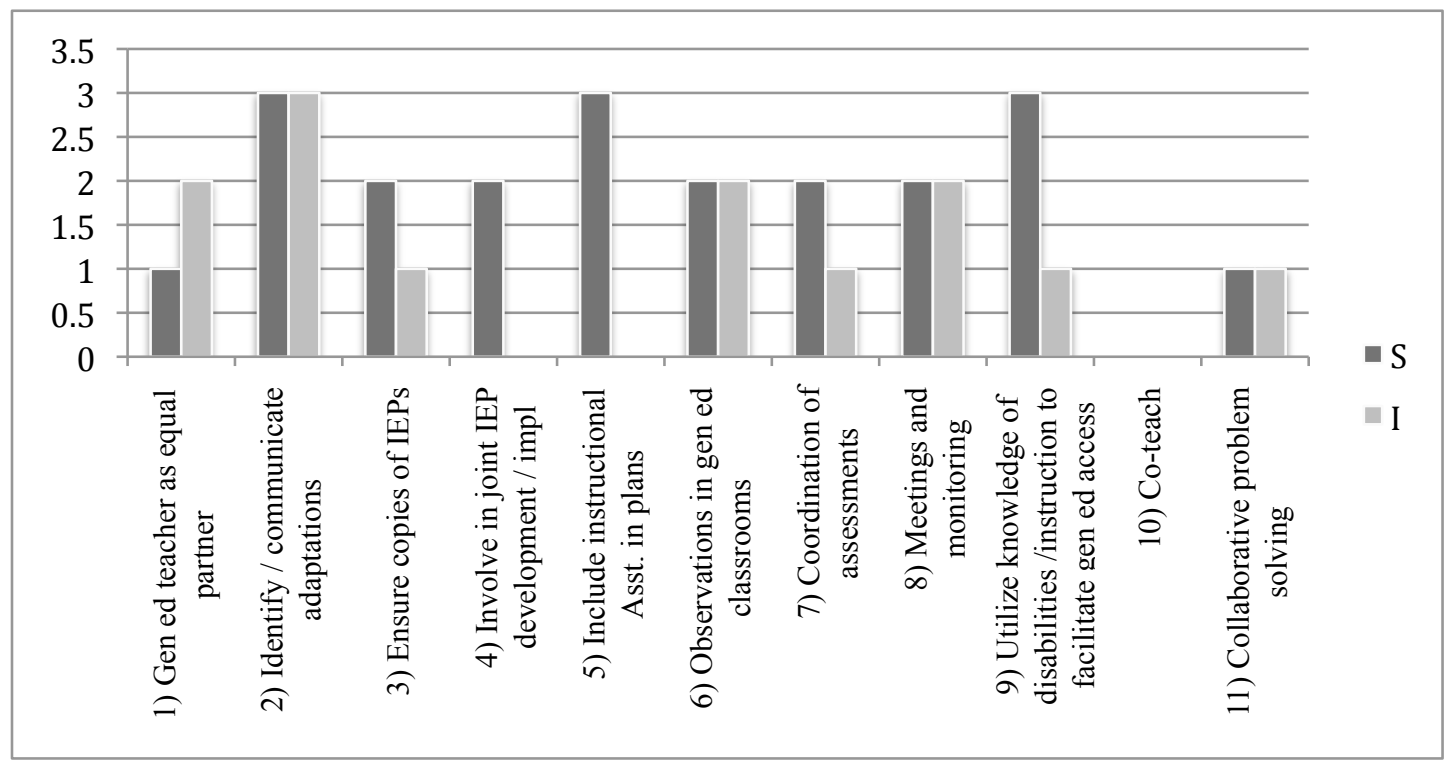

Figure 5. Mentor teacher results per collaborative practice category.

Figure 6 looks at survey and interview responses of special education teacher candidates across settings on extent of collaborative practices. There was no evidence of expectations for ensuring general education teachers had copies of IEPs or for co- 
teaching among the three special education teacher candidates. Special education teacher candidate interviews did not reveal including instructional assistants in collaborative planning with general education teachers, but this was reported as an expectation by two special education teacher candidates on the survey.

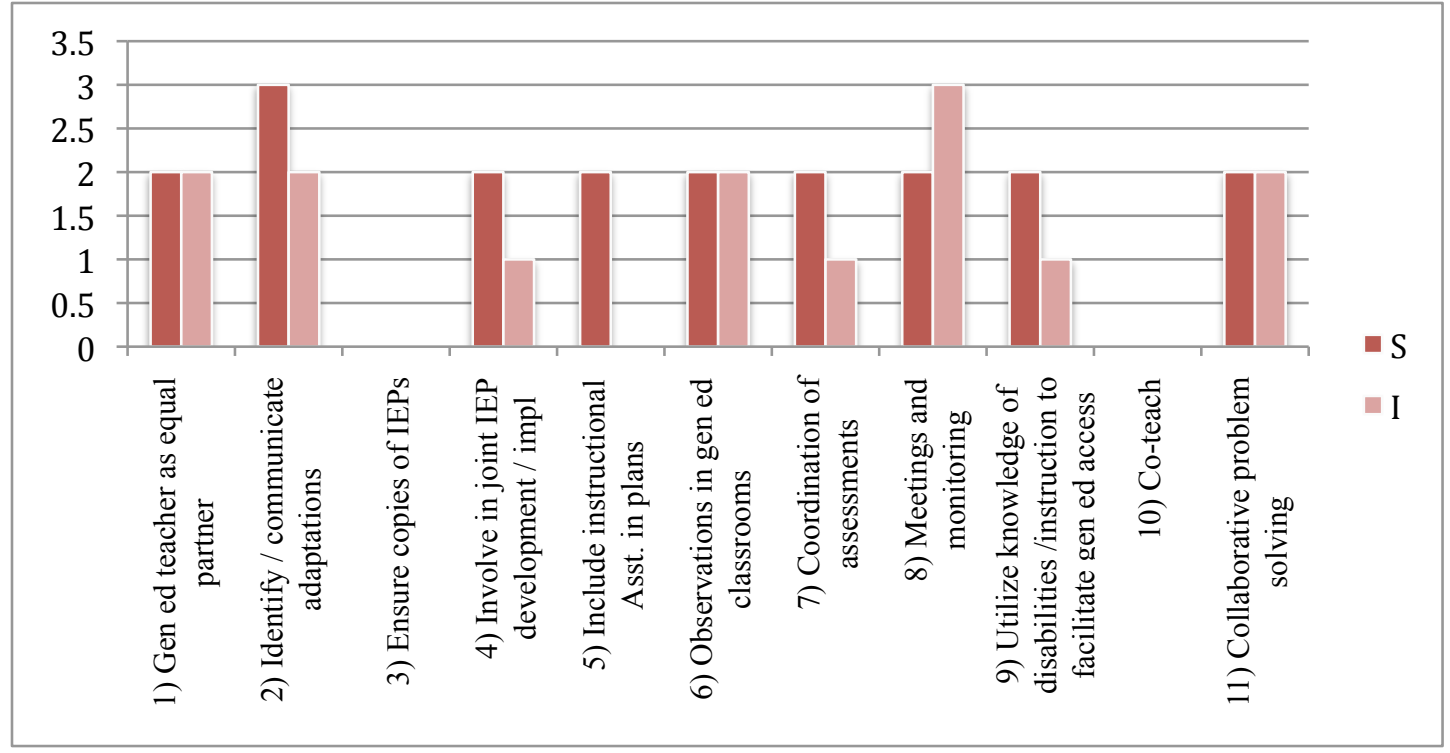

Figure 6. Teacher candidate results per collaborative practice category.

In comparing special education mentor and special education teacher candidate results for collaborative practice categories, a consistent outcome across settings on the survey and interview instruments is no expectation for co-teaching. Two mentor teachers reported an expectation for sharing IEPs with general education teachers, but this was not an expectation of any special education teacher candidate. 
Collaborative practices across settings. The extent that special education

teacher candidates might collaborate with general education teachers during student teaching, was coded using predetermined categories based on a review of the literature on ways special education teachers collaborate with general education teachers (Cook \& Friend, 2007). These categories, referred to as collaborative practice categories, both shaped the survey questions, and became codes for data from interviews, Teaching Work Samples, and Student Teacher Summary Evaluations. Results of the survey and interview on extent of collaborative practices indicate that all collaborative practices were expected in at least one setting, with the exception of co-teaching. There was no evidence of an expectation for co-teaching on either instrument, by either the special education mentor teachers or the special education teacher candidates. The highest collaborative practice expectation on both instruments and across settings was question two: an expectation that special education teacher candidates identify and communicate adaptations to general education teacher.

In two out of the three settings, mentor teachers had expectations that exceeded those of the student teachers. The high school special education mentor teacher had the highest expectations, and the middle school special education mentor teacher had the 
lowest expectations among mentors. Conversely, the high school special education teacher candidate had the lowest expectations on the survey compared to the other settings. The middle school special education teacher candidate had expectations that exceeded those of middle school mentor teacher in both the survey and interview instruments. As illustrated in the example from the follow up interview, language used to define collaboration, and perspectives on roles played a role in the outcome.

Teaching Work Samples and Student Teaching Summary Evaluation documents were coded for anything related to collaboration and/or general education. That data was categorized to narrow the search for collaboration with general education teachers. Text that could be applied to these categories were cross-referenced with the collaborative practices, or new categories were created. There was no evidence that special education teacher candidates were expected to engage in any of the eleven categories of collaborative practice in any of the three work samples used to document teaching effectiveness, or in the Student Teaching Summary Evaluations. Perspectives on collaboration across settings. As indicated in the literature review, positive perspectives toward collaboration are fundamental to the success of collaboration for fostering student success, student learning, and for teaching 
effectiveness. Positive perspectives on collaboration include attitudes that support changing the role of special education teachers from isolation and autonomy toward a more cosultant-consultee model of support, which includes the general education teacher as an equal partner in educating students with disabilities. Common barriers to collaboration and characteristics of effective collaboration were described in the literature review (Cook \& Schirmer, 2006; Friend \& Cook, 2007) to include; communication skills, sustained effort, efficacy, openness, shared responsibility, and reflection that leads to agency. This research compared special education mentor teacher and special education teacher candidate perspectives and attitudes toward collaboration with general education teachers in interview responses and reflections related to collaboration during student teaching experiences.

Organizational categories related to collaboration with general education teachers were established prior the interview. Interpretation happened as themes and patterns emerged from the categories such as expectations, perspectives, and beliefs, which were then codified and classified to describe a phenomenon. Interviews were coded for perspectives on collaboration to include: importance of collaboration, views on benefits to students, successful collaboration, challenges with collaboration, the role of special 
education teachers in collaboration, and preparation of special education candidates for collaboration. Interviews were transcribed and data arranged into substantive categories that reflected beliefs and perspectives related to each question.

The perspectives of special education mentor teachers and special education teacher candidates from each setting were compared in relation to the interview questions, looking for alignment. There was alignment of perspectives at the elementary and high school settings, but not the middle school setting. This does not indicate a causal link or relationship, but may suggest perspectives are shaped by many factors outside of the classroom and student teaching experience.

Of interest was whether mentor perspectives were recognized and/or shared by special education student teachers, and the implications of what might be learned about collaboration in that context, and the influence of the perspective of the mentor teacher. As stated in the theoretical framework, learning in community often happens on the periphery, and observations of communication and actions have an impression on how perspectives are shaped. Reflection also has an impact on learning, with critical reflection having the potential for agency. 
Perspectives on collaboration were most congruent between the high school mentor teacher and high school special education teacher candidate. Perspectives were least congruent in the middle school setting. The elementary school setting had congruency on two out of the six questions. Barriers on collaboration identified in the research were evident throughout the interviews to include time, role ambiguity, and low efficacy (Brownell et al, 2005). In addition, the personal commitment and communication were strong themes of success in both special education mentor and special education teacher candidate reports. Personal commitment as described by Friend and Cook (2007) includes commitment to collaboration, commitment to students, and shared responsibility for student success. All but the middle school mentor teacher reported themes of parity to include shared decision making related to the success of students with disabilities. The middle school mentor teacher viewed the responsibility of the success of students with disabilities to reside with the special education teacher.

A Typology of Reflection Rubric (Appendix C) was used to code text as descriptive, comparative, and critical as evidence of agency. The elementary special education mentor teacher, high school special education teacher candidate, and middle school special education teacher candidate met criteria for comparative reflections. The 
elementary special education teacher candidate and the middle school special education mentor teacher met criteria for a descriptive reflection. The high school special education mentor teacher was the only participant to meet criteria for critical reflection. Although learning from experiences can be enhanced by all three reflective practices, critical reflection is believed to lead to agency and change. The high school mentor teacher expressed ideas for improving the system of education for students with disabilities, and demonstrated a moral commitment to social justice for this population. 


\section{Chapter 5}

\section{Discussion}

In this study I explored the experiences that special education teacher candidates have collaborating with general education teachers during student teaching in elementary, middle, and high school settings. A multi-case study approach was used to research the following questions: (a) To what extent are special education teacher candidates expected to collaborate with general education teachers during student teaching, and (b) How are perspectives on collaboration different between special education teacher candidates and their mentor teachers. The purpose of this research was to gain an understanding of what special education teacher candidates are learning about collaboration with general education teachers during student teaching, to inform programs preparing special education candidates for this role in schools.

Although special education teachers collaborate with many professionals and parents in their role as case manager and special educator, this research study focused specifically on collaboration between general and special education teachers, as a practice that supports learning and achievement for students with disabilities. I did not investigate the various ways special education teachers collaborate with other professionals, students, 
or families. Nor did I investigate the role or perspectives of the general education teachers in the targeted settings in relation to collaboration, or collaboration specifically in support of inclusion. In addition, the structure of general and special education teacher education programs, as separate, integrated or overlapping, was not explored in this study. The purpose of this study was to see what special education candidates were experiencing incidentally in their field placement related to collaboration, by looking at various sources of data.

The special education teacher candidates in the study took a course on collaboration in the teacher education program, prior to their student teaching. Many of the components of collaboration (Friend \& Cook, 2007) and characteristics of a successful collaborator (Friend and Shirmer, 2005) were discussed in this class beyond the collaborative practices with general education teachers. One teacher candidate mentioned how the content of this course provided a new perspective on collaboration while student teaching. The impact and implications of this course on collaborative practices or perspectives was not part of this research study, but it is likely it made an impression on special education teacher candidates. Specific to this research was to understand if collaboration with general education is occurring, and what is expected of 
special education teacher candidates. There is an increasing demand for collaboration between general and special education teachers to bridge curriculum, support inclusion, and prepare students with disabilities for testing and graduation. This study is preliminary in exploring this phenomenon in special education teacher preparation.

\section{Discussion of Results of Research Question One}

To what extent are special education teacher candidates expected to collaborate with general education teachers during student teaching? The extent of the engagement of special education teacher candidates in collaborative practices during student teaching was explored using pre-determined categories based upon both the work of Friend and Cook (2007), and national standards for special education teacher preparation. The collaborative practices are performances specific to the role of special education teachers in a newer paradigm of education, where students with disabilities are increasingly included in general education classrooms, and special education teachers are increasingly integrated into the school.

The survey and interview results from mentors and special education teacher candidates suggest that all collaborative practices were observed or experienced, with the exception of co-teaching. The most consistently reported collaborative practice across 
settings was identifying and communicating adaptations for instructional methods and materials to general education teachers. Survey and interview results on the extent of collaborative practices showed a pattern in which elementary and high school special education mentors reported higher expectations for collaborative practices than the special education teacher candidates. This would be expected, considering mentors are lead teachers with established relationships in the schools, and ultimate responsibility for student success.

The special education students in the elementary and high school special education settings were more involved in general education classrooms and curriculum than the middle school special education students, and therefore providing more opportunities for teacher candidates in the elementary and high school settings to observe and participate in collaboration. This study showed the extent of collaborative practice was indeed highest in elementary and high school settings, but there were limits to the extent of collaboration with general education teachers in each setting based on the classroom practices and on the position of the special education teacher candidates as guests in the classroom. The elementary special education mentor teacher reported he did not feel set up or confident enough to engage in team teaching, or expecting special 
education teacher candidates to team teach. He emphasized that building relationships for collaboration takes time, beginning at the start of the school year, and involves a degree of efficacy on the part of the special education teacher. He believed most important is commitment to the process, building trust, being accountable, being humility, and fostering regular communication.

The high school special education mentor teacher had the strongest relationship with general education teachers, revolving around state testing and graduation. There was high congruency in number of collaborative practices expected, and systems of collaboration were built into the school structure. The high school special education mentor indicated an expectation that the special education teacher candidates ensure general education teachers have access to IEPs, but the high school teacher candidate did not indicate this as an expectation in the survey or interview. This was likely because IEP's are made available through Tie-net (software). Through this system, general education teachers can see IEPs anytime by logging in with their password. In the high school setting, general and special education teachers met frequently in classrooms, and as part of professional development committees. Relationships had grown since the start of the school year, and adaptation strategies were established by spring. The special 
education teacher candidate experienced more collaboration around testing due to the time of year.

A surprising outcome of the research was the discrepancy in the pattern with the middle school special education mentor teacher, in the extent of collaborative practices expected and perspectives on collaboration. Compared to the elementary and high school settings, the middle school special education mentor expected few collaborative practices with general education teachers, viewed her role as more of an expert in the school, and her primary goal for collaboration was to exposure to different people and environments. One explanation might be the severity of the disabilities of the students in that setting, and perspectives about the role of special education teachers in relation to these students. This was a life skills classroom, where the students were significantly below grade level in many subjects and need more support than most students that age in daily self-care and social skills. These students would typically not be included in state assessments. The middle school mentor teacher viewed the role of collaboration as mostly to expose students with disabilities to general education settings, and for general education students and teachers to be exposed to students with disabilities. 
The middle school special education teacher candidate had views on collaboration that included more parity and goals for more alignment with general education curriculum. She saw herself as engaged in more collaborative practices than the mentor teacher listed. In this way, the results of the survey and interview of the middle school teacher candidate contrasted the mentor teacher, and followed a different pattern than the other case studies. The course on collaboration was mentioned by the middle school teacher candidate as a factor in her perception of what collaboration is and why it's important. She maintained a perspective that collaboration is important for sharing the responsibility and success of all students, despite a traditional special education school model where the special education teacher is the expert, and students with severe disabilities are the responsibility of the special education teachers.

Another surprising outcome of the study was the lack of documentation across settings of special education teacher candidate learning of collaborative practices specific to working with general education teachers, in alignment with research. It was evident that general practices of collaboration in schools was addressed in the student teaching evaluation as stated in standards, but not specific to working with general education teachers. In addition, collaboration was not addressed in the teaching work samples. 


\section{Discussion of Results of Research Question Two}

How are perspectives of collaboration different between special education teacher candidates and their mentor teachers? A perspective is a point of view or judgment held toward situations and events. Perspective is influenced by attitudes and attitude impacts learning from experience. The literature review includes research on the effect of positive attitudes on collaboration with general education teachers. The interview questions were designed to learn about perspectives on the purpose of collaboration, challenges of collaboration, successes of collaboration, views on the role of special education teachers in the collaborative process, and views on preparation for the collaborative role in teacher education. The purpose of this research method was to see how mentor and special education teacher candidate responses aligned, considering they shared the student teaching experience, albeit from different positions.

Transcriptions and notes from the interview on the perspectives of special education mentors and special education teacher candidates across settings showed high congruency at the high school level, and no congruency at the middle school level.

Overall, themes in the interviews were consistent with the research on challenges and success related to inclusion. General themes across participants include the importance of 
building personal relationships, importance of building trust, and commitment to ongoing communication. Time constraints and general education teacher resistance were mentioned as some of the main barriers to successful collaboration. Resistance to collaboration was attributed to the culture of the teacher, rather than leadership, with the exception of the middle school mentor teacher perspective. Two of the three mentors reported older teachers are more often less interested in collaboration.

The perspective of the middle school mentor teacher was aligned with traditional practices of isolation and autonomy for both special education students and teachers. The students in special education were regarded by the middle school mentor teacher as "our kids", and general education students as "their kids". This interviewee also posed the greatest number of barriers or challenges of all those interviewed. It is possible that perspectives on collaboration are different depending on the goals for the students. Additional studies would be needed across multiple setting to draw this conclusion. The middle school mentor teacher attributed separate administrations as the main barrier to communication, collaboration, and being a part of a learning community.

Typologies of reflection were classified as descriptive, comparative or critical (Jay \& Johnson, 2000). Although these types cannot predict agency in teachers, they do 
reveal dispositions conducive to positive change and innovation. Like the widening of a lens, typologies expand to include increasingly broader perspectives on events and experiences that can help with seeing possibilities for change. A descriptive reflection is most narrow, and focusing on technical aspects of events and experiences. The middle school mentor teacher reflections lacked a broader perspective on limitations and possibilities for collaboration, placing them into a descriptive typology. The middle school special education teacher candidate considered other perspectives on the limitations of collaboration in her experience, and posed solutions but fell short of mentioning broader social implications of social justice, placing her reflections in a comparative typology. A presumption of this research study is the middle school mentor teacher is not only less likely to be an agent of change, but more likely to maintain traditional practices of separation between special and general education systems of education. A recommendation from this study is for teacher candidates to have coursework on collaboration and reflective practice prior to student teaching to provide a foundation of skills and knowledge for evaluating and reflecting on collaboration experiences in student teaching, to transcend traditional school models. 
Recommendations were made by mentor teachers to better prepare special education teacher candidates for collaboration by having expectations in teacher education that guide collaboration in field placements with a variety of teachers to meet the needs of students with various disabilities. Also recommended by the high school mentor teacher was that special education teacher candidates write reflections on what they observe in relation to collaboration. Special education teacher candidates reported a desire for more collaboration experiences with different general education teachers, and one special education teacher candidate expressed a desire to practice co-teaching.

Mentor teachers consistently reported that it takes time to build relationships with general education teachers, and it starts at the beginning of the school year. This is important for teacher education programs to consider when student teacher placements occur in the spring. Special education teacher candidates will likely be observing collaboration that has been established for several months. It's important to consider what they can realistically be expected to do during student teaching, in collaborative relationships.

\section{Future Implications}

Preparing special education teachers for collaboration means preparing them to develop skills in communication, organization, problem solving, conflict management, 
behavior management, curriculum adaptation, teambuilding, and leadership. It is clear in the research that teacher education programs need to better prepare general and special education candidates for collaboration, and models for how to do this are just beginning to emerge. An integrated general and special education licensure program is one approach for providing a foundation in communication skills and collaboration strategies that foster effective working relationships in schools, and more research is needed to see how these preparation models better prepare candidates to collaborate. Regardless if general and special education teacher preparation is parallel or integrated, it is important to identify how the role of special education teachers is different from general education teachers in fostering and maintaining collaboration, and determining what is reasonable to expect during student teaching.

The tools used by the university that were analyzed as part of this study to evaluate student teacher effectiveness were based on standards, but did not include expectations of specific ways special education teacher candidates collaborate with general education teachers. If we rely on teaching standards alone to guide what we look for in teachers, we may miss an opportunity to ask for performances that are important but not clearly articulated. Based on the findings of this research, and components of 
collaboration framework presented by Friend and Cook (2007), I propose that the first three of the five components depicted would be reasonable indicators of collaboration for special education teacher candidates (personal commitment, communication skills, and interaction processes). The other two components, programs or services and school context, are more dependent on the school structure and largely out of the bounds of what special education teacher candidates and teacher preparation programs can control or influence.

A programmatic recommendation based on this research would be for teacher education to embed content regarding communication and collaboration in the preparation of special education teachers, and look for opportunities to connect theory to practice in field-based experiences, with measurements that guide and document collaboration with general education to support meeting the needs of students with disabilities in accessing general education curriculum, standards, and classrooms. Additional criteria that could be added to field placement evaluations, or be an extension of a course on collaboration, may include observations of collaboration practices to include each of these components, and written reflections of those collaboration practices 
that demonstrates personal commitment and skills for collaboration as an emerging teacher.

A policy recommendation based on this research is that state licensure and program standards be reviewed and revised in conjunction with the changes in national standards for special education preparation to reflect changes in legislation in support of inclusion and collaboration (Blanton, et. al., 2011). Outcomes in teacher education are accountable to state standards for licensure, which I argue makes states equally responsible to preparing candidates for collaboration that increases access to general education curriculum and classrooms. A revision of the language used in work sample requirements for teacher candidates and standards for licensure to include collaborative planning and teaching would reflect principles of effectiveness for teaching diverse learners as outlined in INTASC (2013).

Research recommendations as a result of this study are to further investigate how collaborative roles might be different based on types of special education students, classrooms, and school levels. It was not clear in this study if the differences in collaborative practices and perspectives toward collaboration at the middle school level were due to separate administration for special education, school level, the severity of 
needs of students, or the background of the special education teachers. Additional studies

on the frequency and quality of each collaborative practice in different types of

classrooms at the three different school levels would provide a richer description of the extent of engagement of special education teacher candidates in collaborative practices during student teaching.

\section{Conclusion}

This multiple-case qualitative study explored the extent that special education teacher candidate collaborated with general education teachers during student teaching placements. A theoretical framework was introduced as a way to explain or predict ways in which special education teacher candidates collaborated during student teaching.

Proposed in that framework was that special education teacher candidates are learning about how to collaborate from the periphery, that language and culture reflect perspectives, and that critical reflection could foster an orientation toward fostering and sustaining collaborative practices, regardless of the culture of the school. Teacher education has a role to play in helping special education teacher candidates understand elements of effective collaboration, and develop dispositions and skills for taking on this role in schools. 
The literature review identifies research, standards and legal mandates that signify a shift in schools and teacher preparation to more collaboration. This study focuses specifically on the preparation of special education teachers for their unique role in fostering collaboration with general education teachers. Research supports pre-service coursework on theories of collaboration, as well as experiences with collaboration in field placements.

A critical factor in collaborative school cultures is the attitudes and leadership of school administrators, but such leadership is not consistent. Finding schools that have good collaborative models for special education teacher candidates can be difficult. This research argues special education teacher candidates need to develop skills and beliefs regarding collaboration to become a teacher leader and play a role in shaping a collaborative school culture. The pilot study described in this paper revealed how likely it is that new special education teachers conform to school norms that are traditional and autonomous. The results of this research identify collaborative practices that special education teacher candidates can learn, and illustrates how teacher education programs can play a role in the development of skills and dispositions for fostering and sustaining collaborative practices in the formative stages of becoming a teacher. 
Evident in this research is that special education teacher candidates need more opportunities and perhaps more direction to learn about collaboration with general education teachers. They may not have the time to build relationships with general education teachers, or the skills of a master special education teacher, but there are collaborative practices that special education teacher candidates can engage in during student teaching to help prepare them for this role as professionals.

Teaching work samples and student teaching evaluations are used to measure teaching effectiveness for special education for state licensure. One conclusion of this research is that collaboration with general education is happening during student teaching, but is not captured in these measurements of effectiveness. Teacher collaboration in planning, teaching, and assessment is essential in new standards of teaching effectiveness for diverse learners. A lack of field-placement assignments and documentation related to collaboration with general education teachers can result in missed opportunities for targeted learning and performance evaluation related to collaboration during special education student teaching.

This study provides preliminary information in an area of research where more studies are needed. The results of this study are limited to one particular teacher 
education program and student teaching experiences at three schools, but could lead to additional research in the area of collaboration between general and special education teachers. Building upon this research, there is a need for more case studies in elementary, middle and high schools focusing on how collaboration practices and perspectives are different depending on mentor teacher experience, coursework in teacher education, school levels, or the severity of the disability of students. In addition, looking at the quality of reflection types on teacher agency over time could strengthen the relevance of pedagogy for critical reflection in teacher education. 


\section{References}

Ackerman, R. \& Mackenzie, S. (Eds.). (2006). Uncovering teacher leadership: Essays and voices from the field. Thousand Oaks, CA: Corwin Press.

Arthaud, T. J., Aram, R. J., Breck, S. E., Doelling, J. E., Bushrow, K. M. (2007). Developing collaboration skills in pre-service teachers: A partnership between general and special education. Teacher Education and Special Education; 30 (1), $1-12$.

Austin, A. E. (2001). Reviewing the literature on scholarly collaboration: How we can understand collaboration among academic couples. In E. G. Creamer \& Associates, Working equal: Academic couples as collaborators (pp. 130-145). New York: Routledge Falmer Press.

Berg, B. L., \& Lune, H. (2012). Qualitative research methods for the social sciences $\left(8^{\text {th }}\right.$ ed.) Boston, MA: Pearson.

Billingsley, B. S. (2004). Special education teacher retention and attrition: A critical analysis of the research literature. The Journal of Special Education, 38(1), 39-55.

Blanton, P., Pugach, M. C., \& Florian, L. (2011). Preparing general education teachers to improve outcomes for students with disabilities. American Association of Colleges for Teacher Education. Retrieved 2/1/12 from www.aacte.org.

Blumer, H. (1969). Symbolic Interactionism. Englewood Cliffs, NJ: Prentice-Hall.

Bogdan, R. C. \& Biklen, S. N. (1998). Qualitative research for education: An introduction to theory and methods. Needham Heights, MA: Allyn \& Bacon.

Bos, C. S., and Vaughn, S. (2002). Teaching students with learning and behaviour problems $\left(5^{\text {th }} \mathrm{ed}\right)$. Boston: Allyn and Bacon. 
Brownell, M. T., Adams, A., Sindelar, P., Waldron, N., \& Vanhover, S. (2006). Learning from collaboration: The role of teacher qualities, Exceptional Children, 72, 169185.

Brownell, M. T., Ross, D. D., Colon, E. P., \& McCallum, C. L. (2005). Critical features of special education teacher preparation: A comparison with general teacher education. The Journal of Special Education, 38(4). 242-252.

Brownlie, F., and King, J. (2000). Learning in safe schools. Yorke, ME: Pembroke.

Buell, M. J., Hallam, R. \& Gamel-McCormick, M. (1999). A survey of general and special education teachers' perspectives and in-service needs concerning inclusion. International Journal of Disability, Development, and Education, 46, $143-156$.

CEC (2009) What every special educator must know: Ethics, standards, and guidelines for special educators (5th ed). Arlington, VA:Council for Exceptional Children.

Cook, L., \& Friend, M. (1995). Co-teaching: Guidelines for creating effective practices. Focus on Exceptional Children, 28(3), 1-16.

Cook, B. G., Tankersley, M., Cook, L., \& Landrum, T. J. (2000). Teachers' attitudes toward their included students with disabilities. Exceptional Children, 67. 115135.

Cook, B. G., \& Schirmer, B. R., (2006). What is special about special education? Examining the role of evidence-based practices. Austin, TX. PRO-ED

Coombs-Richardson, R. \& Mead, J. (2001) Supporting general educators inclusive practices. Teacher Education and Special Education: The Journal of the Teacher Education Division of the Council for Exceptional Children, 24, 383-390.

Creamer, E. (September/October, 2004). Collaborators' attitudes about differences of opinion. Journal of Higher Education, 75(5), 556-571. 
Creswell, J.W. (2005). Educational research: Planning, conducting, and evaluating quantitative and qualitative research. ( ${ }^{\text {nd }}$ ed.) Upper Saddle River, NJ: Merrill Prentice Hall.

Darling-Hammond, L. (2006). Constructing $21^{\text {st }}$ century teacher education. Journal of Teacher Education, 57, 300-314.

Dertmer, P., Thurston, L. P., \& Dyck, N. (2002). Consultation, collaboration and teamwork for students with special needs. Boston: Allyn \& Bacon.

Deshler, D. D., \& Schumaker, J. B. (1986). Learning strategies: An instructional alternative for low-achieving adolescents. Exceptional Children, 52(6), 583-590.

Dingle, M., Falvey, M. A., Givner, C. C., \& Haager, D. (Spring, 2004). Essential special and general teacher competencies for preparing teachers for inclusive settings. Issues in Teacher Education, 13(1). 35-50.

Driscoll, M. (2000). Psychology of learning for instruction. ( $2^{\text {nd }}$ ed.) Needham Heights, MA: Allyn and Bacon

Fennick, E., \& Liddy, D. (2001). Responsibilities and preparation for collaborative teaching: Co-teachers' perspectives. Teacher Education and SpecialEducation, 24, 229-240.

Fisher, D., Frey, N., \& Thousand, J. (2003). What do special educators need to know and be prepared to do for inclusive school work? Teacher Education and Special Education, 26, 42-50.

Friend, M. (2000). Myths and misunderstandings about professional collaboration. Remedial and Special Education, 21, 130-132.

Friend, M., \& Cook, L. (2007). Interactions: collaboration skills for school professionals (5th ed.). Boston: Allyn and Bacon. 
Friend, M., \& Bursuck, W. D. (2002). Including students with special needs: A practical guide for classroom teachers (3rd ed.). Needham Heights, MA: Allyn \& Bacon.

Friend, M., \& Cook, L. (2010). Co-Teaching: An illustration of the complexity of collaboration in special education. Journal of Educational and Psychological Consultation, 20(9), p. 9-27.

Freire, P. (2006). Pedagogy of the oppressed. New York: NY. The continuum International Publishing Group Inc.

Fullan, M. (2006). Leading professional learning. School Administrator, 63 (10), 1-5.

Gallagher, P. A., Vail, C. O., \& Monda-Amaya, L. (2008). Perspectives of collaboration: A content analysis of student journals. Teacher Education and Special Education, 31(1), 12-20.

Griffin, C. C., Jones, H. A., \& Kilgore, K. L. (2006). A qualitative study of student teachers' experiences with collaborative problem solving. Teacher Education and Special Education, 29, 44-55.

Griffin, E. (2012). Communication. A First Look at Communication Theory. ( $8^{\text {th }}$ ed.) New York, New York. McGraw Hill.

Hargreaves, A. (1994). Changing teachers, changing times: Teachers' work and culture in the postmodern age. New York: Teachers College Press.

Harvey, M. W., Yssel, N., Bauserman, A. D., \& Merbler, J. B., (2010). Preservice teacher preparation for inclusion. An exploration of higher education teacher-training institutions. Remedial and Special Education, 31(1), 24-33.

Henning, J. E., DeBruin-Parecki, A., Hawbaker, B. W., Nielsen, C. P., Joram, E., \& Gabriele, A. (2005). The teacher work sample: A tool for scaffolding and assessing preservice teachers' early field experiences. The Teacher Educator, 40(3), 188-207. 
Holloway, I. (1997). Basic concepts for qualitative research. Oxford: Blackwell Science.

Hudson, P., and Glomb, N. (1997). If it takes two to tango, why not teach both partners to dance? Collaboration instruction for all educators. Journal of Learning Disabilities, 30, 442-449.

Hoover, J, \& Patton, J. (2004). Differentiating standards-based education forstudents with diverse needs. Remedial and Special Education, 25(3), 74-78.

Individuals with Disabilities Education Improvement Act. (2004). P. L. 108-446, 118 Stat. 2647.

Interstate New Teacher Assessment and Support Consortium. (2013). Model core teaching standards: A resource for state dialogue. Washington DC: Council of Chief State Schools Officers. Retrieved April, 2013 from http://www.ccsso.org/Resources/Publications/InTASC_Model_Core_Teaching_St andards_and_Learning_Progressions_for_Teachers_10.html

Institute of Education Sciences (IES). National Center for Education Statistics. Retrieved June, 2013 from http://nces.ed.gov/ccd/schoolsearch/

Jay, J. K. \& Johnson, K. L. (2000). Capturing complexity: a typology of reflective practice for teacher education. Teaching and Teacher Education, 18. 73-85

Johnson, D. W., \& Johnson, R. T. (1994). Learning together and alone: Cooperative, competitive, and individualistic learning. ( $4^{\text {th }}$ Ed.) Boston: Allyn \& Bacon.

Jorgensen, C. M., Schuh, M. C. \& Nisbet, J. (2006). The inclusion facilitator's guide. Baltimore, Maryland: Brooks Publishing Co.

Jordan, A., Schwartz, E., \& McGhie-Richmond, D. (2009). Preparing teachers for inclusive classrooms. Teaching and Teacher Education, (25), 535-542 
Kalyanpur, M. \& Harry, B. (1999). The culture of special education: Building reciprocal family-professional relationships. Baltimore, MD: Paul H. Brookes.

Kilgore, K., Griffin, C., Otis-Wilborn, A. \& Winn, J. (2003). The problems of beginning special education teachers: Exploring the contextual factors influencing their work. Action Teacher Education, 25(1), 38-47.

Knackendoffel, E. A., Robinson. S. M., Deshler, D. D., \& Schumaker, J. B. (1992). Collaborative problem solving: A step-by-step guide to creating educational solutions. Lawrence, KS: Edge Enterprises.

Kohler-Evans, P. A. (2006). Co-teaching: How to make this marriage work in front of the kids. Education, 127, 260-264.

LaBoskey, V. K. (1994). Development of reflective practice: A study of preservice teachers. New York, NY: Teachers College Press.

Lave, J., \& Wenger, E. (1991). Situated learning: Legitimate peripheral participation. New York: Cambridge University Press.

Le Page, P., Courey, S., Fearn, E. J., Benson, V., Cook, E., Hartmann, L. \& Nielson, S., (2010). Curriculum recommendations for inclusive teacher education. International Journal of Whole Schooling, 6(2), 19-27.

Linton, S. (1998). Claiming disability: Knowledge and identity. New York and London: New York Press.

Lipton, L, \& Wellman, B.(September, 2007 ) How to talk so teachers will listen: Teacher leaders encourage professional growth by engaging colleagues in positive conversations about their teaching practices. Education al Leadership, 65(1), 3034

Mayring, P. (2000). Qualitative content analysis. Forum: Qualitative Social Research, 1(2). Retrieved April 5, 2012, from http://www.qualitative research.net/index.php/fqs/article/view/75/153 
Maxwell, J. A. (2005). Qualitative research design. An interactive approach. ( $\left.2^{\text {nd }} \mathrm{ed}\right)$. Thousand Oaks, CA. Sage Publications, Inc.

McConney, A., Schalock, M., \& Schalock, H. D., (1997). Indicators of student learning in teacher evaluation. In J. Stronge (Ed.), Evaluating teaching: A guide to current thinking and best practice (pp. 162-192). Thousand Oaks, CA: Corwin.

McLesky, J., \& Waldron, N. L. (2004). Three conceptions of teacher learning: Exploringthe relationship between knowledge and the practice of teaching. Teacher Education and Special Education, 27, 3-14.

McKenzie, R. G. (2009). A national survey of pre-service preparation for collaboration. Teacher Education and Special Education, 32(4), 379-393.

National Center for Special Education Personnel and Related Service Providers (NASDSE) Retrieved April 20 $0^{\text {th }}, 2012$ from http://www.personnelcenter.org

NCATE. (2008). Professional standards for the accreditation of teacher preparation institutions [Electronic Version]. Retrieved from http://www.ncate.org/ institutions/publicationsbooks.asp? $\mathrm{ch}=49 \&$ book=standards.

Nisbet, J. (2004). Caught in the continuum. Research \& practice for persons with severe disabilities. 29(4) p. 231-236.

No Child Left Behind Act (2001). Pub. L. No. 107-110, 115 Stat. 1425. U.S. Department of Education. Retrieved April, 2012 from http://www2.ed.gov/policy/elsec/leg/esea02/index.html

Pugach, M. C., Blanton, L. P., Correa, V. I., McLeskey, J., \& Langley, L. K. (2009). The role of collaboration in sup- porting the induction and retention of new special education teachers (NCIPP Doc. No. RS-2). Gainsville, FL: Univeristy of Florida,

National Center to Inform Policy and Practice in Special Education Professional Development. Retrieved 2/10/13 from http://ncipp.education.ufl.edu. 
Pugach, M. C., \& Warger, C. L. (2001). Curriculum matters: Raising expectations for students with disabilities. Remedial and Special Education, 22, 194-196.

Rea, P. J., Mclaughlin, V. L., \& Walther-Thomas, C. (2011). Outcomes for students with learning disabilities in inclusive and pullout programs. Exceptional Children, 68(2), 14-29.

Reinhiller, N. (1999). Efficient and effective formats for collaborative consultation. Journal of Educational and Psychological Consultation, 10, 173-184.

Robinson, L., and Riddle Buly, M. (2007). Breaking the language barrier: Promoting collaboration between general and special educators. Teacher Education Quarterly, 34 (3), 83-94.

Rocco, T. S. (2006). Disability as an issue of marginalization. In Merriam, S. B., Courtenay, B. C.,Cervero, R. M., \& McClure, G. Global Issues and Adult Education: Perspectives from Latin America, Southern Africa, and the United States. Jossey-Bass, San Francisco, CA.

Rogers, D., \& Babinski, L. (2002). From isolation to conversation: Supporting new teachers' development. Albany, NY. State University of New York Press.

Shippen, M. E., Crites, S. A., Houchins, D. E., Ramsey, M. L., \& Simon, M. (2005). Preservice teachers' perspectives of including students with disabilities. Teacher Education and Special Education, 28, 92-99.

Schalock, M. (1998). Accountability, student learning, and the preparation and licensure of teachers: Oregon's teacher work sample methodology. Journal of Personnel Evaluation in Education, 12, 269-285.

Schalock, M., Cowart, B., \& Staebler, B. (1993). Teacher productivity revisited: Definition, theory, measurement, and application. Journal of Personnel Evaluation in Education, 7, 179-196. 
Scruggs, T.E., \& Mastropieri, M.A. (Fall, 1996). Teacher perspectives of mainstreaming / inclusion, 1958-1995: A research synthesis. Exceptional Children, 63 (1), 59-74.

Schön, D. A. (1987). Education and the reflective practitioner: Toward a new design for teaching and learning in the profession. San Francisco: Jossey-Bass.

Silverman, J. C. (2007). Epistemological beliefs and attitudes toward inclusion in preservice teachers. Teacher Education and Special Education, 30,42-51.

Sloan, K. (2004). Between the "inputs" and "outputs": Assessing the effects of high stakes accountability on educational quality. In A. Valenzuela (Ed.), Leaving children behind: How "Texas-style" accountability fails Latino Youth (pp. 136160). New York: State University of New York Press.

Smith, R. \& Leonard, P. (2005). Collaboration for inclusion: Practitioners perspectives. Equity and Excellence in Education, 38(4), 269-279

Snell, M. E. \& Janney, R. (2005). Collaborative teaming. Teachers' guide to inclusive practices. $\left(2^{\text {nd }}\right.$ Ed.) Baltimore, Maryland. Paul H. Brooks Publishing.

Soodak, L. C., Podell, D. M., and Lehman, L. R. (1998). Teacher, student and school attributes as predictors of teachers' responses to inclusion. The Journal of Special Education, 31, 480-497.

Stanovich, P. J., \& Jordan, A. (2002). Preparing general educators to teach in inclusive classrooms: Some food for thought. The Teacher Educator, 37, 173-185.

Teacher Standards and Practices Commission. Oregon Administrative Rules. Retrieved 05/10/13 from http://arcweb.sos.state.or.us/pages/rules/oars 500/oar 584/584 017.html

Thousand, J. S., Villa, R. A., \& Nevin, A. I., (2002). Creativity and collaborative learning: The practical guide to empowering students, teachers, and families. Baltimore: Paul H. Brookes Publishing Co. 
Udvari-Solner, A. (1996). Theoretical influences on the establishment of inclusive practices. Cambridge Journal of Education, 26(1), 101-120.

U.S. Department of Education. (2002). Education department submits $23^{\text {rd }}$ annual report to Congress on Special education. Retrieved April 20 ${ }^{\text {th }}, 2012$, from http://www.ed.gov/news/pressreleases/2002/05/05102002.html

Valli, L. (1997). Listening to other voices: A description of teacher reflection in the United States. Peabody Journal of Education, 72(1), 67-88.

Villa, R. A., Thousand, J. S., \& Chapple, J. W. (1996). Preparing teachers to support inclusion: Preservice and inservice programs. Theory into Practice, 35(1), 42-50.

Voltz, D. L., \& Elliott, R. N., Jr. (1997). Collaborative teacher roles in facilitating inclusion: Preservice preparation for general and special educators. The Teacher Educator, 33, 44-60.

Wasburn-Moses, L. (2009). An exploration of pre-service teachers' expectations for their future roles. Teacher Education and Special Education, 32(1), 5-16.

Welch, M. \& Brownell, K. (2002). Are professionals ready for educational partnerships? The evaluation of a technology-enhanced course to prepare educators for collaboration. Teacher Education and Special Education, 25(2), 133-144.

Yin, R. K. (2003). Case study research design and methods. ( $3^{\text {rd }}$ ed.) Thousand Oaks, CA: Sage Publications.

Zeichner, K. M. \& Liston, D. P. (1996). Reflective teaching: An introduction. Mahwah, New Jersey: Lawrence Erlbaum Associates.

Zahorik, J. A. (1987). Teachers' collegial interaction: An exploratory study. The Elementary School Journal, 87(4), 385-388. 
Appendix A

Interview Protocol 


\begin{tabular}{|l|}
\hline Interview Questions for Special Education \\
Teacher Candidate \\
\hline Tell me about the classroom where you did \\
your student teaching: \\
- what type of classroom is it? \\
- What is the main purpose of your room? \\
How many students are in the room? How \\
- What are the primary disabilities of \\
students in the room?
\end{tabular}

What do you believe is important about collaborating with general education teachers?

How does collaboration with general education teachers help students with disabilities?

What makes collaboration with general education teachers successful?

What are the challenges to collaboration with general education teachers?

What did you observe or experience about collaboration between the special and general education teachers during your student teaching?

To what extent did you communicate with general education teachers about the progress of students in your classroom?

To what extent did you refer to or inquire with the general education teacher when planning and teaching your work sample?

What more would you have liked to know or experience about collaboration with general education teachers in your student teaching experience?

\section{Interview Questions for Mentor Teachers}

Tell me about your credentials and teaching experience

Tell me about your classroom:

- what type of classroom is it?

- What is the main purpose of your room?

- How many students are in the room? How many assistants?

- What are the primary disabilities of students in the room?

What do you believe is important about collaborating with general education teachers?

How does collaboration with general education teachers help students with disabilities?

What makes collaboration with general education teachers successful?

What are the challenges to collaboration with general education teachers?

How often and in what ways do you collaborate with general Ed teachers?

What do you see as the role of the special education teacher in fostering collaboration with general education teachers?

What kind of preparation have you had to prepare you to collaborate with general education teachers?

What do you believe is important for special education teacher candidates to learn and do in preparation for collaboration general education teachers?

What do you think special education candidates learned about collaboration with general education teachers during student teaching? 


\section{Appendix B}

Collaborative Practices Survey and Checklist 


\begin{tabular}{|c|c|c|c|c|}
\hline $\begin{array}{l}\mathrm{Y}=\text { yes, it was indicated this was expectation of teacher } \\
\text { candidate } \\
\mathrm{N}=\text { no, it was indicated this was not an expectation of } \\
\text { teacher candidate } \\
-=\text { absence of documentation in document }\end{array}$ & $\begin{array}{l}\text { Mentor } \\
\text { Teacher }\end{array}$ & $\begin{array}{l}\text { Student } \\
\text { Teacher }\end{array}$ & $\begin{array}{l}\text { Work } \\
\text { Sample }\end{array}$ & $\begin{array}{l}\text { Field } \\
\text { eval }\end{array}$ \\
\hline $\begin{array}{l}\text { 1) Was there an expectation the special education } \\
\text { teacher candidate include the general education teacher } \\
\text { as an equal partner in the planning, delivery and } \\
\text { assessment of student learning? } \\
\text { IGC10K4 Co-planning and co-teaching methods to strengthen } \\
\text { content acquisition of individuals with learning exceptional } \\
\text { learning needs }\end{array}$ & & & & \\
\hline $\begin{array}{l}\text { 2) Was there an expectation for the special education } \\
\text { teacher candidate to identify and communicate } \\
\text { adaptations for instructional methods and materials to } \\
\text { general education teachers? } \\
\text { ICC10S8 Model techniques and coach others in the use of } \\
\text { instructional methods and accommodations }\end{array}$ & & & & \\
\hline $\begin{array}{l}\text { 3) Was there an expectation the sped teacher candidate } \\
\text { ensure general education teachers had copies of IEPs } \\
\text { and were addressing IEP goals in the general education } \\
\text { classroom? }\end{array}$ & & & & \\
\hline $\begin{array}{l}\text { 4) Was there an expectation the sped teacher candidate } \\
\text { participate in facilitating the involvement of general } \\
\text { education teachers during the development and } \\
\text { implementation of Individualized Education Plans? }\end{array}$ & & & & \\
\hline $\begin{array}{l}\text { 5) Was there an expectation the sped teacher candidate } \\
\text { include instructional assistants in collaborative plans } \\
\text { with general education teachers? } \\
\text { ICC10S11 Observe, evaluate, and provide feedback to } \\
\text { paraeducators }\end{array}$ & & & & \\
\hline $\begin{array}{l}\text { 6) Was there an expectation the sped teacher candidate } \\
\text { observe students with disabilities in the general } \\
\text { education classroom? } \\
\text { ICC10S6 Collaborate with school personnel and community } \\
\text { members in integrating individuals with exceptional learning } \\
\text { needs into various settings }\end{array}$ & & & & \\
\hline $\begin{array}{l}\text { 7) Was there an expectation the sped teacher candidate } \\
\text { coordinate assessments with the input and feedback of } \\
\text { general education teachers? } \\
\text { ICC10S2 Collaborate with families and others in assessment of } \\
\text { individuals with exceptional learning needs }\end{array}$ & & & & \\
\hline $\begin{array}{l}\text { 8) Was there an expectation the sped teacher candidate } \\
\text { participate in meetings and progress monitoring with } \\
\text { general education teachers? }\end{array}$ & & & & \\
\hline $\begin{array}{l}\text { 9) Was there an expectation sped teacher candidate } \\
\text { utilize knowledge of disabilities or research-based } \\
\text { instruction with general education teachers to facilitate } \\
\text { access to general education standards, curriculum } \\
\text { and/or instruction? } \\
\text { ICC10S9 Communicate with school personnel about the } \\
\text { characteristics and needs of individuals with exceptional learning } \\
\text { needs }\end{array}$ & & & & \\
\hline $\begin{array}{l}\text { 10) Was there an expectation sped teacher candidate } \\
\text { would Co-teach or Team Teach with general educators } \\
\text { IGC10K4 Co-planning and co-teaching methods to strengthen }\end{array}$ & & & & \\
\hline
\end{tabular}


content acquisition of individuals with learning exceptional learning needs

11) Was there an expectation sped teacher candidate would participate in collaborative problem solving

ICC10S7 Use group problem-solving skills to develop,

implement, and evaluate collaborative activities 
Appendix C

Typology of Reflection Rubric 


\begin{tabular}{|l|l|l|}
\hline Dimension & Definition & $\begin{array}{l}\text { Features } \\
\text { for reflection }\end{array}$ \\
\hline Descriptive & $\begin{array}{l}\text { Tells what is happening, for whom it is } \\
\text { working or not working, feelings about } \\
\text { what is observed or experienced, } \\
\text { questions, concerns, considers who } \\
\text { benefits and who does not benefit, own } \\
\text { perspectives and feelings, and own } \\
\text { understandings of what is happening or } \\
\text { not happening. }\end{array}$ \\
\hline Comparative & $\begin{array}{l}\text { Reframes the matter in } \\
\text { light of alternative } \\
\text { views, others' } \\
\text { etc. }\end{array}$ & $\begin{array}{l}\text { Considers alternative views of what is } \\
\text { happening. States how other people who } \\
\text { are directly or indirectly involved describe } \\
\text { and explain what is happening. Considers } \\
\text { how the research contributes to an } \\
\text { understanding of this matter. Thinks of } \\
\text { how to improve and what's not working. } \\
\text { Understands there is a goal and how it is } \\
\text { accomplished }\end{array}$ \\
\hline Critical & $\begin{array}{l}\text { Having considered the } \\
\text { implications of the } \\
\text { matter, establishes a } \\
\text { renewed perspective } \\
\text { and judgment }\end{array}$ & $\begin{array}{l}\text { Considers the implications of the matter } \\
\text { when viewed from alternative } \\
\text { perspectives. Given alternative views and } \\
\text { their implications, and own morals and } \\
\text { ethics, considers what is best in this } \\
\text { matter. Considers the deeper meaning of } \\
\text { what is happening in terms of public } \\
\text { democratic purposes of schooling. } \\
\text { Considers what experience reveals about } \\
\text { moral and political dimensions of } \\
\text { schooling. Considers how reflective } \\
\text { process informs and renews own } \\
\text { perspective and takes responsibility. }\end{array}$ \\
\hline
\end{tabular}

Source: Adapted from Jay, J. K., \& Johnson, K. L. (2000). Capturing complexity: a typology of reflective practice for teacher education. Teacher and Teacher Education 18 pp. $73-85$ 